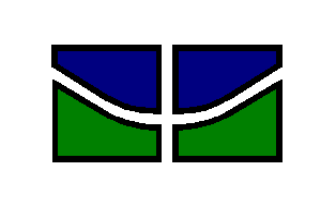

UNIVERSIDADE DE BRASÍLIA - UNB

INSTITUTO DE CIÊNCIAS HUMANAS - IH

DEPARTAMENTO DE SER VIÇO SOCIAL - SER

\title{
AS ADOLESCENTES EM CUMPRIMENTO DE MEDIDAS SOCIOEDUCATIVA DE INTERNAÇÃO NO DISTRITO FEDERAL: ONDE FICA O “GÊNERO”? (2006-2008)
}

ANA CAROLINA DA SILVA SILVÉRIO

Brasília (DF), dezembro de 2008. 
TRABALHO DE CONCLUSÃO DE CURSO

\begin{abstract}
AS ADOLESCENTES EM CUMPRIMENTO DE MEDIDAS SOCIOEDUCATIVA DE INTERNAÇÃO NO DISTRITO FEDERAL: ONDE FICA O “GÊNERO”? (2006-2008)
\end{abstract}

\author{
Trabalho de Conclusão de Curso \\ apresentado para diplomação no \\ curso de Serviço Social na \\ Universidade de Brasília, sob \\ orientação da Prof. $^{\text {a }}$ Patrícia \\ Pinheiro.
}

\author{
Banca Examinadora: \\ Professora Mestre Patrícia Cristina P. de Almeida (orientadora) \\ Assistente Social Thais Alves Moreira \\ Professor Doutorando Luiz Fernando Viegas
}

Brasília (DF), dezembro de 2008. 


\section{INDÍCE ANÁLITICO}

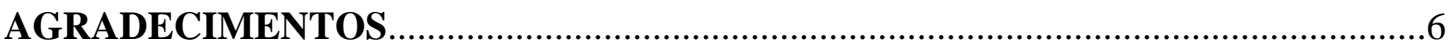

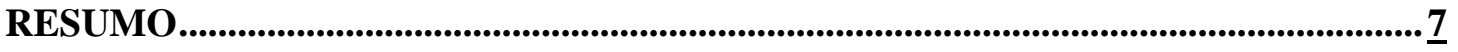

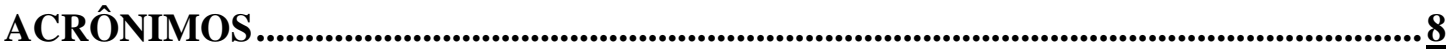

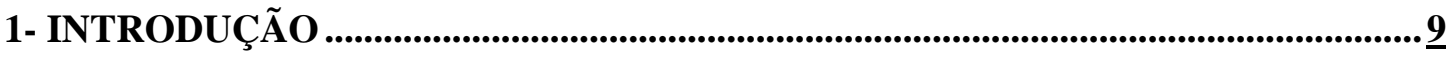

1.1 Pergunta de Pesquisa................................................................................................................ 15

1.2 Hipótese de Pesquisa ......................................................................................................................... 15

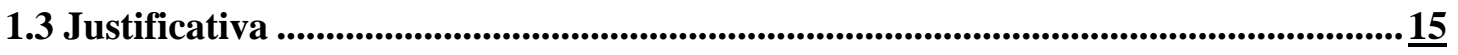

1.3.1 Importância do Estudo no Contexto da Formação como Assistente Social .......... 15

1.3.2 Importância do Estudo em relação ao Conhecimento Científico............................ 18

1.3.3 Importância do Estudo em relação às Políticas Públicas.......................................... 20

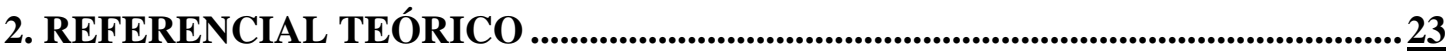

2.1 Concepção de gênero...............................................................................................23

2.1.1 O que é Gênero? - Suas Origens e Desdobramentos................................................... 23

2.1.2 Dicotomia Sexo/Gênero: Papéis Sexuais, Sistema Binário, Identidade e Diferença de Sexo/Gênero.......................................................................................................... 27

2.1.3 Gênero e Poder.......................................................................................................... 31

2.1.4 Gênero, Patriarcado e Sexismo....................................................................... 34

2.1.5 A Reinvidicação às especificidades de Gênero: O Feminismo....................... 36

2.2 Política de Proteção a Crianças e Adolescentes (Marco Regulatorio)............................38

2.3 Brasil e o Estatuto da Criança e Adolescente - ECA.......................................................42

2.4 Adolescentes Infratorxs e a perpetuação do descaso das instituições

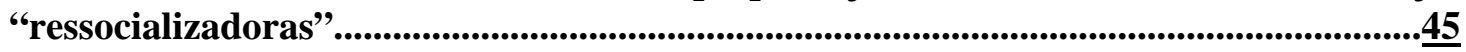

2.5 Medidas Socioeducativas de Internacao no Brasil............................................................50

2.6 Medida Socioeducativa de Internação no Distrito Federal............................................ 
2.7 Unidades de Internação no Distrito Federal "CAJE" - Cento de Atendimento Juvenil

Especializado.....................................................................................................................................55

2.8 Adolescente Infratora.....................................................................................................................58

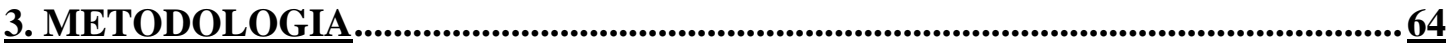

3.1 Método ........................................................................................................................................................ 6 66

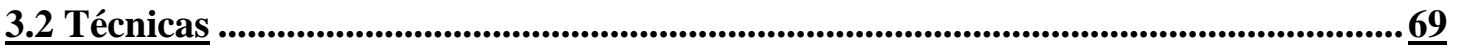

4 APRESENTACૃ̃̃O E ANÁLISE DO OBJETO DE ESTUDO

4.1 ELAS X ELES: O Capital institucionalizado no CAJE - "Discurso da igualdade de gênero forja desigualdades insuperáveis e a critica ao enquadramento para abafar as diferenças de gênero"'......................................................................................................................................................71

4.1.1 SOBRE ELAS: A construção socio-cultural da categoria Gênero e seu impacto no CAJE - Perfil das Adolescentes e Demandas Institucionais . $\underline{77}$

4.1.1.2 ELAS X ELAS: Historias deVida: Pagu, Anastácia e Bell - Diários e Relatos. $\underline{85}$

4.1.1.3 MIOPIA DO ESTADO: Ausência de políticas públicas de gênero no CAJE como opção politica. . .91

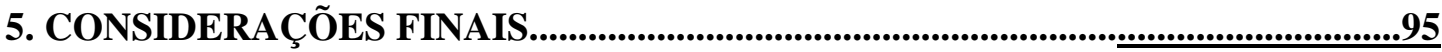

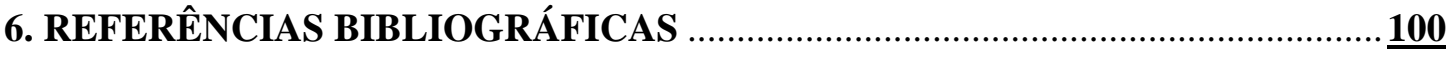

7. ANEXOS.........................................................................................................................................110

7.1 ANEXO I - Instrumental I - Roteiro para coleta das informações retirada dos CAJE/CIAGO - Pesquisa "CAJE HOJE” Erro! Indicador não definido.110

7.2 ANEXO II - Instrumental II - Orientações para os pesquisadores de campo CAJE/CIAGO - Pesquisa "CAJE HOJE" 
7.3 ANEXO III - Instrumental Entrevistas Adolescentes CIAGO/CAJE - Pesquisa "CAJE HOJE" $\underline{113}$

7.4 ANEXO IV - Instrumental Levantamento Documental - Biliografia 119

7.5 ANEXO V - Musica "Vida Loca" Parte I e II do Grupo de RAP "Racionias Mc's"

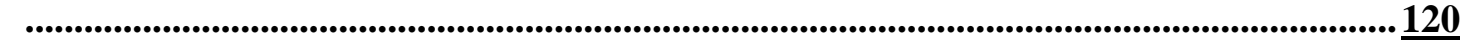




\section{AGRADECIMENTOS}

Dedico essa Monografia em primeiro lugar a minha mãe D. ANA (Ana Maria da Silva) e ao meu pai GILMOUR (Gilmar Silvério) pelo amor incondicional e por me ensinarem a caminhar sem tocar os pés no chão de um mundo racista, homofôbico, sexista e opressor; agradeço também pela paciência cotidiana, compreensão vocês são tudo na minha vida; sem demagogia nós "somos uma família". MOZA meu coração que me inspirada todos os dias olhos de biloca caramelizada amadeirada és a tradição cultural da minha essência eu te amo eterno shashimi de deusa. Obrigada a minha irmã Camila Helena a brutinha mais doce que eu conheço contigo aprendo a ser mais pragmática e menos "sonhadora" mesmo você não me amando eu te amo de graça. A minha vozinha e meu vozinho (in memorian) por me levarem ao samba para me benzer dos mal agoros da vida, o legado que vocês deixaram é bunito de se ver. Tia Leninha, Tio Lula vidas graciosas cheias de carinho e tesão. José "imbecil" Thouseff mais que marido, um amante da vida, compactuamos de um amor transcendental que a palavra amizade não consegue explicar eu sei já fomos ligados em outras vidas amo-te. Manga Rosa amizade para vida toda hermanita única e parceirada temos uma segunda família: Au au au o quarteto é animal! Tatiana Nascimento "Barsinha para adultos" tudo que sei de feminismo aprendi com você Preta Mágica: perola negra literalmente se não fosse tu esse TCC não sairia você sabe disso! Prof. Newton por me ensinar a acreditar na "revolução" e como ser uma boa tia do seu bichinho de estimação o hipopótamo Hermínio viciado em sorvete de creme. Artur DeBoa "Tutis Rolão" e Isabel "Beu Vovozinha": é musica é irmandade são doces deletérios. Tia Josélia seus filhxs são belos assim como sua essência. Marina Leite a "Crazyrina peladona da L2" a única pessoa que agregou-se ao quarteto muito quiridinha. Comadi e Cumpadre "Pintas e Pirrita" cadê nasce nosso Juninho? Flor, Tatu pela casa maravilhosa pelos inconformismos e por lutarmos por um mundo sem machismo quando vamos fazer mais feijão? Ao pessoal do CEDECA, VIOLES-SER-UnB pelas experiências com pesquisa que desmascarem as desigualdades sociais sejam elas quais forem. A todas as pessoas feministas que lutam por realidades não mais ou ao menos, não tão silenciadoras, misóginas, machistas, racistas, hierarquistas, enfim, tão violentas para nós mulheres. Ao correria que ganhou meu notebook você desconstruiu muitas coisas em mim querendo ou não aprendi com você. As professoras Patrícia Pinheiro, Maria Lucia Pinto Leal e Luiz Fernando Viegas que me conduziram em minha vida acadêmica, me ajudando a diminuir as dificuldades dessa vivência, sinistra e cabulosa. A Thais Alves Moreira por ter topado essa empreitada. A Domingas por todo o apoio na secretaria do departamento. Ao Doutor meu psicólogo favorito. Banda Sub-Versão (Tio, Banda e DeMelo) e em especial a DA CAPO “só quem é vai sentir" a musicalidade me faz acreditar que um outro mundo é possível, milito através da voz. Faço dos mozas-versos e dos higi-versos o que chamo de política cotidiana eu te amo musica em toda sua negritude pulsante! A todas as parcerias do Movimento Hip Hop - DF. E por fim a "Farofa Social" (in memorian) e ao planeta que resiste "bravamente" em meio a tanto lixo produzido; "uma vergonha"! 


\section{RESUMO}

Este Trabalho de Conclusão de Curso é um estudo caso sobre as adolescentes em cumprimento de Medidas Socioeducativa de Internação do Distrito Federal (DF), realizado no Centro de Atendimento Juvenil Especializado - CAJE, acerca da categoria "gênero. O objetivo principal é demonstrar se o Estado, na figura do CAJE considera a categoria "gênero" na construção das Políticas Públicas voltadas para adolescentes infratoras no Distrito Federal. Para isso, considerou-se a Política de Proteção a Crianças e Adolescentes (marco regulatorio), o Sistema Nacional SocioEducativo, o Estatuto da Crinça e do Adolescente, as Políticas Públicas de Gênero, as Medidas Socioeducativa de Internação no Brasil e no DF , o histórico das adolescentes infratoras, o "Capital" institucionalizado no CAJE em um discurso da igualdade de gênero que forja desigualdades insuperáveis e a critica ao enquadramento para abafar as diferenças de "gênero", como de deu a construção social da categoria gênero no CAJE (perfil das adolescentes e as demandas institucionais), a historia de vida de três adolescentes visando reconhecer seu local de fala e como suas especificidades construídas pelo "gênero" é garantida pelo Estado, a miopia do Estado e a ausência de políticas publicas de gênero no CAJE como uma opção política. Para embasar a análise foram escolhidas teorias que tratam sobre construção social do gênero, dicotomia sexo/gênero, papéis sexuais, sistema binário, identidade e diferença de sexo/gênero, patriarcado, poder, políticas publicas sensíveis a categoria gênero e o papel do Estado. Estas teorias nos permitem compreender o contexto em que o CAJE está inserido e dar base para a análise do estudo de caso. A metodologia utilizada para a realização da pesquisa foi Feminista para Pesquisa Social, na qual o estudo de caso foi o CAJE. As técnicas utilizadas foram à análise documental, e à de historia de vida que o estudo de caso permitiu através do método feminista de analise e a técnica dos "múltiplos métodos". Foi concluído que o Estado constrói uma política que homogeneíza adolescentes do sexo masculino e feminino, perante o sistema socioeducativo. Isso indica que o aparelho estatal não dá atenção as especificidades de gênero, sendo míope e desconsidera as assimetrias sociais. O trabalho tem como ponto de partida a reflexão dessa constatação, evitando as analises teóricas, as políticas e os programas "neutros" do ponto de vista do gênero. O tratamento supostamente neutro certamente implica na desconsideração dos papéis desempenhamos pela mulher, com prejuízo para sua posição na sociedade.

PALAVRAS-CHAVE: Adolescente Infratora, Gênero, Centro de Atendimento Juvenil Especializado(CAJE), Método Feminista, Estudo de Caso, Políticas Publicas . 


\section{ACRÔNIMOS}

Associação Brasileira de Magistrados e Promotores da Infância e Juventude (ABMP)

Centro de Atendimento Juvenil Especializado (CAJE)

Centro Brasileiro para a Infância e a Adolescência (CBIA)

Centro de Atendimento Juvenil Especializado (CAJE)

Centro de Defesa dos Direitos da Criança e do(a) Adolescente (CEDECA)

Centro de Integração do Adolescente Granja das Oliveiras (CIAGO)

Centro Latino Americano de Estudos de Violência e Saúde Jorge Careli (CLAVES)

Centro Socioeducativo Amigoniano (CESAMI)

Conselho de Defesa dos Direitos da Pessoa Humana (CDDPH)

Conselho Nacional dos Direitos das Crianças e dos(as) Adolescentes (CONANDA)

Departamento da Criança e do Adolescente (DCA)

Departamento Geral de Ações Sócio-Educativas (DEGASE)

Departamento Intersindical de Estatísticas e Estudos Socioeconômicos (DIESE)

Estatuto da Criança e do(a) Adolescente (ECA)

Fórum Nacional de Organizações Governamentais de Atendimento à Criança e ao Adolescente (FONACRIAD)

Fundações Estaduais do Bem-Estar dos(as) Menores (FEBEM's)

Fundo das Nações Unidas para a Infância (UNICEF)

Instituto Brasileiro de Geografia e Estatística (IBGE)

Instituto de Pesquisas Econômicas Aplicadas (IPEA)

Ministério Público do Distrito Federal e Territórios (MPDFT)

Organização das Nações Unidas (ONU)

Política Nacional de Bem-Estar do Menor (PNBEM)

Programa de Assistência Integral à Saúde da Mulher (PAISM)

Secretaria Especial dos Direitos Humanos (SEDH)

Serviço de Assistência ao Menor (SAM)

Sistema de Gestão Democrática (SDG)

Sistema Nacional de Atendimento Socioeducativo (SINASE)

Subsecretaria Especial de Promoção dos Direitos da Criança e do Adolescente (SPDCA)

Trabalho de Conclusão de Curso (TCC)

(VIOLES) 


\section{1- INTRODUÇÃo}

O presente Trabalho de Conclusão de Curso (TCC) tem como objetivo realizar um estudo de caso sobre a ausência de políticas públicas que contemplem a categoria "gênero" em relação a adolescentes em cumprimento de medidas socioeducativas de Internação no Distrito Federal. O recorte temporal da pesquisa se inicia no ano de 2006 e termina em junho de 2008 .

Negar as diferenças sejam elas entre os sexos, as classes, as raças/etnias e as de contextos socioculturais existentes, é criar mecanismos que agem de forma invisível e mascarada de reprodução de preconceitos e discriminações, que mantêm uma lógica de submissão e subserviência A prevalência dessa lógica tem solapado as potencialidades individuais e colocado um homem branco, rico, heterossexual em uma posição privilegiada (IRIGARAY e RUBIN, 1998).

Enquanto as diferenças sociais forem mantidas como sinônimo de desigualdade, as políticas públicas universalizantes, ${ }^{1}$ herança do Iluminismo como modo de produção hegemônico do conhecimento nas sociedades ocidentais, continuarão servindo como uma espécie de "tapa buracos" sociais, com ênfase assistencialista bem ilustrada pelos inúmeros programas sociais de natureza compensatória (bolsa-escola, vale gás, etc...), sem propor uma ruptura efetiva com mecanismos de preservação de condições subordinadas para as minorias em geral. O colonialismo europeu finca,_como eixo norteador das relações, uma assimetria entre as pessoas e o Estado. Tais relações se dão no confronto entre inclusão e exclusão, assimilação e resistência, dominante e dominadx, ${ }^{2}$ num processo de diferenciação entre o "nós"e o "eles", colonizador(a) e colonizado(a).

\footnotetext{
${ }^{1}$ As Políticas Públicas na modernidade capitalista, remetem a tendências de universalização versus focalização. Faz-se necessário, contrapor as políticas universalizantes a políticas de discriminação positivas como compensatórias, calcadas nas vulnerabilidades sociais, com focalização nas desigualdades sociais. Nesse contexto chamo atenção para o fenômeno que denomina-se "gestão controlada da exclusão" do momento em que o Estado em vez de observar o direito à diferença, nas políticas de homogeneização cultural, descaracterizou-a numa abordagem universalista que se concretiza de forma normativo-legal. Na contramão do Estado regulador, com suas estratégias universalistas e homogeneizadoras para inclusão, encontram-se, os grupos sociais étnico-raciais, LGBTTT's, movimento feminista, religiosos, deficientes, sindicalistas, que buscam reinventar o Estado, sob novas condições históricas e políticas, com estratégias de empoderamento, pela via da cidadania.

${ }^{2}$ Considero importante afirmar essas relações de confronto reflete a luta anticapitalista, que também é a luta contra o patriarcado, o racismo, a homofobia (as chamadas "desigualdades invisíveis") e outras formas de exclusão. Nesse sentido, é fundamental sair do padrão de mentalidade que tem como modelo geral o homem-branco-heterosexual-ocidental-cristão. Isso inclui desafiar regras gramaticais que instituem o uso do masculino para significar o genérico e reforçam a invisibilidade de, pelo menos, metade da população que se identifica com o gênero feminino. A opção por essa linguagem
} 
Nesse contexto cultural, que transmite de geração em geração uma relação complexa de dominação/submissão, parece "normal” ou "natural” o domínio, considerado inquestionável, do macho branco sobre os demais adultos (figura de sustentação do patriarcado $^{3}$ ), ou da figura de uma mãe repressiva; o que pontua, como exemplo, a colonização mental que perpetua o racismo $^{4}$ e outras figuras de repetição de poder que ampliam sua manutenção e grau de atuação. Esse autoritarismo, visível nas relações mais íntimas e no plano particular, se expressam nas formas incorporadas de violência de gênero, de massacre da individualidade e de opressão do sujeito subordinado (FANON, 1982). Autoritarismo que se amplia e marca as relações sociais num plano mais geral.

O impacto dessas relações de poder e de outras relações, que ditam os padrões de beleza, de gostos e estilos de vida (BORDIEU, 2007), do celular e do tênis da moda, dos $i$ pod cheios de estilo e de todo lixo cultural massificado e globalizado que a grande mídia vende é tão intenso a ponto de fazer que adolescentes pobres optem pela "vida loca"5 marginalidade (única forma de adquirir estes bens).Ao mesmo tempo estes adolescentes pobres tendem a revoltarem-se com a desigualdade em relação ao riquinho de olhos azuis que teve colégio particular depois faculdade (ATHAYDE, BILL e SOARES, 2005) ${ }^{6}$

Mesmo que para isso comprometam suas vidas sob o risco de internação prisional. Esta é uma combinação perversa entre miséria que a população infanto-juvenil esta

sexista reflete mentalidades e moralidades que vêem o homem como padrão, o único digno de representar as mulheres e a humanidade como um todo. Incluir a forma feminina nas palavras genéricas (masculinas) é afirmar a existência das mulheres e dar visibilidade para o fato de que elas também estão em todos os lugares. Entendo adotar como postura uma linguagem inclusiva é, não apenas coerente com o que acredito, mas uma forma de afirmarmos a pluralidade da sociedade e optar por uma "guerrilha de linguagem", na constatação de que o que se fala e se escreve também cria e influencia modos de ser e estar no mundo. Opto pelo formato dessa nova linguagem, ou pela necessidade de uma padronização estilística. É fundamental pensarmos e escolhermos junt@s a melhor forma de expressar a sociedade justa, libertária e inclusiva pela qual estamos lutando: "o/a", "@", "x", ou mesmo a afirmação dos dois gêneros.

${ }^{3} \mathrm{O}$ patriarcado é um modo de estruturação e organização da vida coletiva baseado no poder de um "pai", isto é, prevalece as relações masculinas sobre as femininas; e o poder dos homens mais fortes sobre outros.

${ }^{4} \mathrm{Um}$ dos aspectos fundamentais da ideologia racista é a dimensão ontológica de seus efeitos sobre o escravizado colonizado. FANON (1961), ao abordar os efeitos psicológicos do colonialismo nos colonizados, destaca que esses não foram excluídos apenas do ponto de vista de direitos e privilégios, mas também do ponto de vista de seus pensamentos e valores. Nesse sentido é necessário compreender que a dominação política e a exploração econômica levada a cabo pelo empreendimento colonial europeu foi acompanhada de uma subtração da condição de ser humano - sujeito de vida, cultura e história - do indígena e do africano.

${ }^{5}$ Termo criado por Mano Brown, um dos líderes do maior grupo de RAP do Brasil chamado Racionais MC's chama-se Vida Louca "quem é "guerreiro de fé e nunca gela". Em seus show ele clama ao seus "guerreiros de fé" que digam junto com ele a seguinte frase: "Programado pra morrê nóis é". E os "guerreiros de fé" entoam isso como um hino religioso nos shows, com a mão pro alto e tudo, como se o Mano Brown fosse o general, e os manos os soldados, prontos para a guerra. "Só quem é, que sente" vide a letra da musica em anexo.

${ }^{6}$ MV Bill na música Soldado do Morro, Cd lançado em em 1998 o disco "CDD Mandando Fechado" pelo selo Zâmbia (com produção dos Racionais Mano Brown e Ice Blue), relançado pela Natasha Records/BMG um ano depois com o título "Traficando Informação" 
submersas, e o feitichismo que próprio sistema capitalista engendra e vende aos adolescentes sob rótulos enfeitados, tais como : "Trabalhe e ficará rico", "Viver pouco como um Rei ou muito como um Zé”, que presume uma igualdade de oportunidade moldadas em princípios (a)éticos individualistas mesquinhos e extremamente oportunistas. E o trafico de drogas passa a ser um processo de trabalho desumanizado completamente alienado que cristaliza as relações sociais como mercadoria, e a vida desses jovens passam a não valer nada a não ser a maximização dos lucros dos donos do crime organizado, criando um mundo paralelo, um Estado a parte. Tal afirmação pode ser sustentada no comentário que segue abaixo de György Lukács, Velha e Nova Cultura:

\begin{abstract}
A característica principal da organização social capitalista está no fato de que a produção econômica deixou de ser um instrumento para a função vital da sociedade e se colocou no centro: se converteu em fim em si mesmo, o objetivo de toda a atividade social. A primeira conseqüência, e a mais importante, é a transformação da vida social em uma grande relação de troca; a sociedade no conjunto de suas relações toma a forma de mercado. Nas distintas funções da vida, tal situação se expressa no fato de que cada produto da época capitalista, como também todas as energias dos produtores e dos criadores, reveste a forma de mercadoria. Cada coisa deixou de valer em virtude de seu valor intrínseco (por exemplo, valor ético, valor artístico): tem valor unicamente como coisa vendável ou adquirível no mercado. Tudo o que este realizou destrutivamente sobre toda a cultura expressando-se esta seja em atos, em criações de obras de arte, ou em instituições - é algo que não exige análises ulteriores.

(LUKACS, 1920: p. 54)
\end{abstract}

Surgem, então, novas formas de organização de trabalho que colocam esses [as] adolescentes em máxima vulnerabilidade social, seduzidos[as] pelos padrões hegemônicos do que é ter uma vida digna. É como se a cidadania e o pertencimento a uma cultura estivesse condicionada a um vestir, comer, agir que determina uma igualdade que estilhaça as identidades de classe e pasteuriza comportamentos a partir do que é ditado pelas classes dominantes (SAFFIOTI, 2005). 
Valendo-se de diversas estratégias o jogo das manipulações do imaginário social empreendido pelo capital, apresenta-se a este segmento como uma possibilidade concreta de garantir a plena satisfação de seus anseios de consumo, urdindo um processo que, se valendo da "igualdade imaginada" aliena tanto quanto fragiliza vontades de reagir e buscar novas opções de pertencimento, transformando adolescentes em consumidorxs inertes. Estabelece uma situação de vulnerabilidade associada frustrações pessoais, familiares e sociais.

Os meios de comunicação vendem a idéia de status social de sucesso associada a posse de mercadorias cujos signos estão associados a noções de moderno, jovem e vencedor. Estes mesmos meios também incendeiam preconceitos, reforçam diferenças e adormecem a opinião pública diante da violência contra jovens pobres que "ousaram" se verem iguais e que sofrem toda sorte de abusos nos centros de "reeducação do Estado". A idéia desses centros remete cada vez mais a de cadeias, depósitos de indesejáveis, de sobrantes da sociedade de consumo, bem diferente da idéia vendida para esses meninos e meninas de um sonho de igualdade para quem ostentasse os símbolos corretos de pertencimento. Os centros de internação estão longe de serem socioeducativos. As "Medidas Socioeducativas" não se realizam ali. A política no Sistema SocioEducativo do Distrito Federal (DF) é, efetivamente, de contenção e extermínio da juventude, pobre e negra ${ }^{7}$ (FLAUZINA, 2008). Não só extermínio físico, estampado na violência física que as e os adolescentes sofrem pela figura de agentes carcerários(as), mas também psicológico e simbólico, uma vez que as internações pintam o quadro deprimente do descaso estatal quanto às garantias de bem-estar e segurança de adolescentes em situação de cumprimento de medidas socioeducativas.

Segundo o Conselho Nacional dos Direitos das Crianças e dos(as) Adolescentes (CONANDA) - pelo menos 17 estados não têm unidades de Internação ou Semiliberdade especiais para meninas. O estudo apontou, ainda, um déficit de 3.396 vagas nas 366 Fundações Estaduais do Bem-Estar dos(as) Menores (FEBEM's) do país; além de delegacias, jovens infratorxs estão abrigadxs em locais superlotados. Uma inspeção do CONANDA em

\footnotetext{
${ }^{7}$ Ana Luiza Pinheiro Flauzinha em: Corpo Negro Caído no Chão- O Sistema Penal e o Projeto Genocida do Estado Brasileiro (2008), toma o racismo como uma doutrina, uma ideologia ou um sistema sobre o qual se apóia um segmento populacional considerado superior, por causa de características fenotípicas ou culturais, a fim de conduzir e subjugar um outro, tido como inferior. Além de todos os aspectos presentes na definição, destacamos expressamente o caráter desumanizador inscrito na concepção de racismo. Essa peculiaridade faz dele uma das justificativas mais recorrentes nos episódios de genocídio e em toda sorte de vilipêndios materiais e simbólicos que tenham por objetivo violar a integridade dos seres humanos.
} 
maio de 2000 no Espaço Recomeço (EREC), no Pará, o aponta como o pior do País: vazamentos de esgoto correm pelo chão, não há luz nem camas e, superlotado desde 2002, tem 138 jovens em espaço para 48 e os jovens são obrigados a dividir redes para conseguir dormir (CONANDA, 2006).

No Distrito Federal a realidade não é diferente. Apesar das Unidades para cumprimento das medidas socioeducativas terem sido construídas em plena vigência do Estatuto da Criança e do(a) Adolescente (ECA) e, portanto, não terem herdado a estrutura das antigas instituições correcionais-repressivas de atendimento juvenil do Brasil (VOLPI, 1999), não deixaram de herdar a mentalidade conservadora que impedem a efetivação das mudanças e não problematiza a questão do gênero e o tratamento adequado para adolescente do sexo feminino dentro das suas espeficidades.

O Centro de Atendimento Juvenil Especializado (CAJE) $)^{8}$ é um bom exemplo. Sendo a única Unidade de Internação para adolescentes infratoras no Distrito Federal, o local é sombrio, imundo e a impressão que se tem é que as paredes foram pintadas muitas vezes para mascarar a hostilidade e a repressão impregnada por ali. Os chamados "quartos", mais parecidos com celas, são verdadeiras jaulas insalubres e lotadas. É chocante a opressão dos "porcos", alcunha que as/os adolescentes usam para se referir às/aos carcereiros/policiais: exigem que as/os internxs mantenham a cabeça sempre baixa e fiquem de mãos para trás, em um estado de subserviência e submissão. Caso saiam dessa posição, "o couro come". Se não se mantiverem na condição de submissão que lhes foi determinada desde o primeiro dia de internação, sucedem-se agressões físicas e toda sorte de constrangimentos morais, para lembrar-lhes sua condição de infratorxs da lei. As agressões com tapas e ofensas verbais são utilizadas para que fiquem cientes de que a postura domesticada é um tipo de penalização a qualquer comportamento considerado "desviante".

Sem estabelecer uma escala de opressões e violências, ou afirmar que determinadas configurações identitárias ${ }^{9}$ agregam mais sofrimento, mais opressão a determinados sujeitos

\footnotetext{
${ }^{8}$ CAJE é o Centro de Atendimento Juvenil Especializado. Além desse centro, visitei o CIAGO - Centro Amigoniano Granja das Oliveiras. As visitas aconteceram entre os meses de janeiro à dezembro do ano de 2006.

${ }^{9}$ Segundo o dicionário de Direitos Humanos Brasileiro (2006), as configurações identitárias são entendidas como identidade cultural, e se organiza como um sistema de representação das relações entre pessoas e grupos, que envolve o compartilhamento de patrimônios comuns como a língua, a religião, as artes, o trabalho, os esportes, as festas, entre outros. É um processo dinâmico, de construção continuada, que se alimenta de várias fontes no tempo e no espaço. Como
} 
sociais identificáveis em categorias (como o segmento de mulheres, ou mulheres negras, ou indígenas, ou lesbianas, ou cadeirantes, ou homens brancos gays ricos, ou pobres para citar algumas), pois não se trata de criar hierarquias que categorizem determinadas pessoas como mais ou menos oprimidas.

As diversas opressões existentes submetem as pessoas a uma vida menos feliz, com menos bem-estar, com menos acesso a bens materiais e imateriais, não funcionam de maneira estanque nem são mensuráveis; elas se articulam para sufocar possibilidades de liberdade. É importante ressaltar, que a despeito de como entendamos os diversos traços que nos formam, existe efetivamente algum tipo de opressão que tenta desvalorizá-los, como é o caso do racismo, do sexismo, do classismo, por exemplo, que tentam fazer com que diferenças de raça, sexo/gênero e classe sejam hierarquizantes (GOMES, 2005)

O conceito de gênero, ao enfatizar as relações sociais entre os sexos, permite a apreensão de diferenças entre homens e mulheres, que envolve, como um de seus componentes centrais, as desigualdades de poder. ${ }^{10}$ Nas sociedades ocidentais, marcada também por outros 'sistemas de desigualdade', como apontado pela abordagem pósestruturalista, é possível constatar, no entanto, que o padrão dominante nas relações entre pessoas adultas de gêneros diferentes envolve uma situação de subordinação e de dominação das mulheres pelos, tanto na esfera pública como na privada. (SUÁREZ e BANDEIRA, 1999)

O trabalho aqui apresentado busca discutir esse conceito de gênero, como postura conceitual e metodológica, considerando as assimetrias sociais que estabelece, parte de um pressuposto comum: mulheres e homens não desempenham os mesmos papéis na sociedade. Em conseqüência, seus interesses e necessidades são diferentes. Qualquer tentativa de reflexão sobre o tema ou intervenção na realidade deve partir desse fato, evitando-se as analises teóricas, as políticas e os programas "neutros" do ponto de vista do gênero. O tratamento supostamente neutro implica, quase que certamente, desconsideração dos papéis desempenhamos pela mulher, com prejuízo para sua posição na sociedade (SAFIOTTI, 1994; SCOTT, 1995 e FUJIWARA, 2002).

conseqüência do processo de globalização, as identidades culturais não apresentam hoje contornos nítidos e estão inseridas numa dinâmica cultural fluida e móvel. 


\subsection{Pergunta de Pesquisa}

O Estado considera a categoria "gênero" na construção das Políticas Públicas voltadas para o cumprimento de Medidas Socioeducativas de Internação para adolescentes infratoras no Distrito Federal?

\subsection{Hipótese de Pesquisa}

O Estado descumpre a proteção às adolescentes infratoras no cumprimento de medida socioeducativa de Internação no Distrito Federal, ao não eleger como principio norteador nas formulações de Políticas Públicas uma perspectiva de gênero, que resultaria em intervenções onde as adolescentes recebessem tratamentos contempladores de suas espeficifidades; ao contrario, sua ação tem optado por intervenções mediadas pela conveniência orçamentária de uma sociedade patriarcal que tende a ignorar as questões de gênero com prejuízos a construção de uma sociedade equânime.

\subsection{Justificativa}

\subsubsection{Importância do Estudo no Contexto da Formação como Assistente Social}

Abre-se a apresentação desse trabalho sobre Medidas Socioeducativas de Internação no DF desde uma perspectiva de gênero com a argumentação do porque entendo ser imprescindível deixar nítido de onde falo, que fundamentação discursiva me dá suporte e filtra todas as visão de mundo, a maneira como se movimenta nele, em determinados lugares de fala, a percepção e intervenção no mundo.

Sendo este trabalho o de conclusão do curso de Serviço Social, é preciso que eu apresente a parcialidade do meu lugar de fala como forma de tentar compartilhar o espaço que ocupo no mundo, e também a forma como o ocupo, tanto com quem está dentro da Universidade - que é, afinal, a instituição que vai possibilitar e legitimar minha atuação profissional - quanto com quem está dentro de outras instituições, em especial às e aos jovens que conheci nos centros de internação do DF.

Essa discussão, tão evitada pelo receio de que se perca a preciosa "neutralidade científica" tida como necessária à práxis acadêmica, não pode ser ignorada aqui. Esse 
trabalho não parte da prerrogativa do distanciamento acadêmico, não trata as/os entrevistadxs como objeto diante de uma pesquisadora.

Como mulher negra dentro da academia, minha trajetória tem sido pautada pela vontade de colocar-me a serviço das comunidades a que pertenço, colocar os conhecimentos adquiridos nela a serviço de mudanças significativas numa realidade que nos rompe, nos separa, empobrece, segrega, exclui, mata. A população negra, figura historicamente como a mais discriminada e vulnerável na sociedade brasileira. Não poderíamos esperar algo muito além de representatividade comprometida se não estamos dentro dos centros de produção de poder e conhecimento. Mas agora faz-se necessário e justo falar sobre as adolescentes, em sua maioria pretas e pardas, de forma comprometida, implicada, pessoal.

Entrar em contato com a realidade das jovens sentenciadas a Medidas Socioeducativas no DF descortinou uma realidade extremamente segregadora. A maioria dxs adolescentes sentenciados(as) a cumprir Medida Socioeducativa - seja ela de Internação, de Liberdade Assistida ou de Semi-Liberdade - é preta ou parda (o movimento negro engloba essa diversidade étnico-racial sob a categoria "negrxs", também adotada pelo Instituto Brasileiro de Geografia e Estatística (IBGE) e pobre, de uma classe social dita como "baixa", o que reforça as relações de poder dominantes com profundas raízes no autoritarismo da tradição classista e racista herdada do colonizador na constituição da nação brasileira.

O interesse por temas relacionados à infância e adolescência surgiu a partir do meu engajamento político no Movimento Hip Hop; das letras que escrevo e canto enquanto Rapper $^{11}$ na musicalidade que a Cultura Hip Hop traz em seu discurso e também a partir de

11 Considerado como uma das práticas mais relevantes da cultura popular contemporânea, o Rap tem sido objeto de estudos em diferentes áreas acadêmicas. Tendo perdido suas origens como prática vernacular afroamericana, emerge no meio dos anos 70, transformando e apropriando-se dos sons e técnicas do estilo « disco ». Hoje essas origens sobrevivem em ressonâncias transformadoras e novas inflexões culturais relocalizadas. Seu discurso crítico, seu interesse pela mixagem de sons, pela colagem de melodias tem sido visto como espelho do nosso tempo. A palavra misturada aos sons sampleados, as fontes musicais superpostas e os movimentos corporais do MC levam muitos a pensar em monotonia e ausência de abstrações; faltam-lhe os artifícios e a complexidade da erudição. O que é forte são suas letras de protesto contra a pobreza, a perseguição e o preconceito tem sido muitas vezes incorporado por outros grupos ou indivíduos que experimentam situações de opressão ou discriminação. Mércia Pinto. RAP: GÊNERO POPULAR DA PÓS-MODERNIDADE (2004) 
conversas informais com os (as) "correrias"12 nas rodoviárias da vida e nas cidades ditas periféricas do Distrito Federal.

A disciplina Estágio em Serviço Social 2 foi cursada ano mesmo período em que participei de uma pesquisa: "CAJE Hoje" 2006. O estágio foi desenvolvido no Centro de Defesa dos Direitos da Criança e do(a) Adolescente (CEDECA). A oportunidade surgiu a partir da experiência no Grupo VIOLES ${ }^{13}$, que proporcionou um estudo da temática relacionada ao projeto de pesquisa do estágio, referente à análise da situação de crianças e adolescentes em internação no CAJE.

O espaço institucional do CEDECA, permitiu o desempenho de atividades ligadas diretamente a uma pesquisa realizada pelo Centro de Defesa dos Direitos da Criança e do(a) Adolescente do Distrito Federal. O nome da Pesquisa, que fez parte das atividades dede estágio, é “O CAJE Hoje: Diagnóstico Social dos(as) Adolescentes em Privação de Liberdade no Distrito Federal"; refere-se ao trabalho desenvolvido sobre a situação dxs adolescentes que se encontravam no CAJE em 2006. Teve como objetivo fazer um estudo profundo acerca de indicadores sociais e econômicos bem como jurídicos dos e das adolescentes em privação de liberdade, confrontando-o com a proposta ideal que legitima a criação do CAJE, sua realidade e ainda a rede de instituições governamentais e nãogovernamentais que participaram, participam ou poderiam participar na recuperação dessxs adolescentes. Ainda visou a contribuição para a proposição de Políticas Públicas de efeito que garantam o cumprimento dos Direitos Humanos, da Constituição Federal de 1988 e do Estatuto da Criança e do(a) Adolescente, e teve por finalidade fornecer uma leitura das diferenças e invariâncias da experiência de privação de liberdade de adolescentes do Distrito Federal.

\footnotetext{
12 Aquele ou aquela que acredita na ideologia da periferia. Geralmente vive do mercado informal. Pode ser definido como segmento cultural popular dotado de um código de conduta, que possui vestimentas, linguajar próprio (gírias), onde o Movimento Hip Hop esta instrisecamente ligado a sua identidade principalmente uma de suas vertentes, o estilo musical do RAP. Vivem em constate estado de vulnerabilidade social, acreditam em perspectivas menos injustas, seriam os (as) anti-heróis e heroínas do caos do mundo moderno. Constantemente ligado a figura de "marginais" e ao consumo de drogas, alguns já vivenciaram a experiência da prisão por pequenos e grandes delitos, incluindo trafico de drogas. (Griffos meus)

${ }^{13}$ Em 2002, integrei o VIOLES - Instituto de Pesquisa especialista em Violências (Violências, Abuso e Exploração Sexual Comercial), sendo convidada a participar da pesquisa "Perfil dos(as) Adolescentes que morreram no cumprimento de medida sócio-educativa - internação, semi-liberdade e liberdade assistida - no Distrito Federal" no período de 2003 a 2005.
} 
O contato direto com adolescentes cumprindo medida de internação colocou, como principal questão motivadora dessa investigação, as políticas públicas de medidas socioeducativas para adolescentes a partir da miopia destas em relação ao gênero. Não pretendo, entretanto, esgotar em um TCC, pelo pequeno fôlego deste, essas perguntas, mas pretendo ao menos identificar prováveis falhas e apontar caminhos possíveis, a partir da prática de Serviço Social, que nos permitam modificar nem que minimamente algumas estruturas dessa sociedade.

\subsubsection{Importância do Estudo em relação ao Conhecimento Científico}

Esta pesquisa pretende reunir elementos para entender como a categoria gênero se manifesta atualmente nas medidas socioeducativas de Internação do DF.

As produções cientificas na contemporaneidade do Mundo Ocidental sobre a categoria gênero trabalhando com homens e mulheres, ou com relação entre elxs, isto é com a consideração de gênero, trazem um enfoque relativamente recente nas ciências sociais, nos movimentos sociais e nas tentativas de intervenção programada na realidade (políticas, planos, programas, projetos sociais do Governo e das organizações não-governamentais), por conta de toda opressão vivenciada pelas mulheres em uma sociedade que tem como norma o patriarcado.

O termo gênero teve sua gênese nos escritos feministas, segundo a historiografia do conceito feito pelo grupo "Em Canto" (1989), e traria a marca da antropologia, em particular a anglo-saxônica, ainda que tenha sido usado em várias disciplinas, por exemplo na linguiística, na literatura e na psicanálise. O grupo Em Canto destaca a "confusão inicial (no uso do termo gênero) com papel sexual".

Nesse trabalho também se delimita um diferença básica entre o uso do termo gênero e o cunhado pela ciência social de corte funcionalista, isto é, papeis sociais. Segundo Em Canto em FRAISSE (1991):

\footnotetext{
"O que a noção de gênero irá precisar é ampliar em relação ao conceito de papeis sexuais e à idéia de simetria e hierarquia nas relações entre homens e mulheres incorporando a dimensão das relações de poder . Usar "gênero" para todas as referências de ordem social ou cultural, e "sexo" para aquelas de ordem biológica. Uma das mais destacadas e criticadas
} 


\begin{abstract}
leituras sobre gênero é sem dúvida o funcionalismo apresentada aqui a partir da leitura de Parsons e Bales que entendem a diferença de gênero no interior da família moderna em termos de papéis "expressivos" (femininos) e papéis "instrumentais" (masculinos). As diferenças entre as mulheres e os homens são estudadas nesta teoria através dos conceitos de papel sexual e status. Nessa leitura, as diferenças sexuais são mais evidentes e cumprem um papel mais central na instituição familiar, pois as relações entre os gêneros funcionam primordialmente para assegurar a reprodução social. Ainda reconhecem que os indivíduos se constroem através da vida social, negando, portanto as visões biológicas e psicológicas sobre a "naturalização" das identidades humanas (EM FRAISSE, 1991, p.9):
\end{abstract}

Entretanto, deve-se incluir aqui alguns dados que dimensionam o peso e importância da problemática a ser abordada.

O campo de estudos de gênero consolidou-se no Brasil no final dos anos 1970, concomitantemente ao fortalecimento do movimento feminista no país. A incorporação da perspectiva de gênero por políticas públicas é, no entanto, um tema ainda hoje pouco explorado (PINTO, 2003).

O conceito de gênero, incorporado pelo feminismo e pela produção acadêmica sobre mulheres nos anos 1970, tem sido interpretado de formas distintas por diferentes correntes do feminismo. Segundo Marília Carvalho, o uso ainda hoje mais freqüente do conceito é o proposto pelo feminismo da diferença. Este rejeitou pressupostos do feminismo da igualdade, que afirmava que as únicas diferenças efetivamente existentes entre homens e mulheres são biológicas-sexuais, e que as demais diferenças observáveis são culturais, derivadas de relações de opressão e, portanto, devem ser eliminadas para dar lugar a relações entre seres ‘iguais'. Constrói-se assim uma polarização binária entre os gêneros, em que a diferença é concebida como categoria central de análise, fundamental na definição de estratégias de ação. (FARAH, 2002)

SCOTT (1994) e CARVALHO (1998) interpreta que as diferenças entre homens e mulheres são enfatizadas, estabelecendo-se uma polaridade entre masculino e feminino, produção e reprodução, e público e privado. Para o feminismo da diferença, o poder concentrar-se-ia na esfera pública, estando nessa polaridade a origem da subordinação das 
mulheres. ${ }^{14}$ A vertente pós-estruturalista, por sua vez, destaca o caráter histórico das diferenças entre os gêneros e a própria construção social da percepção da diferença sexual.

Essa corrente chama a atenção, sobretudo, para a necessidade de se romper com a homogeneização interna a cada um destes campos - o feminino e o masculino -, reconhecendo existência de diversidade no interior de cada um, o que requer que se incorporem à análise, outras dimensões das relações sociais, tais como raça, classe e geração (NICHOLSON, 1994).

\footnotetext{
"Gênero é a organização social da diferença sexual. O que não significa que gênero reflita ou implemente diferenças físicas fixas e naturais entre homens e mulheres, mas sim que gênero é o saber que estabelece significados para as diferenças corporais. Esses significados variam de acordo com as culturas, os grupos sociais e no tempo, já que nada no corpo [...] determina univocamente como a divisão social será estabelecida" (SCOTT, 1994, p. 13, apud CARVALHO, 1998, p. 401).
}

O conceito de gênero, ao enfatizar as relações sociais entre os sexos, permite a apreensão de desigualdades entre homens e mulheres, que envolve, como um de seus componentes centrais, desigualdades de poder (FUGIWARA, 2001). Nas sociedades ocidentais, marcadas também por outros 'sistemas de desigualdade', como apontado pela abordagem pós-estruturalista, é possível constatar, no entanto, que o padrão dominante nas identidades de gênero de pessoas adultas envolve uma situação de subordinação e de dominação das mulheres, tanto na esfera pública como na privada (CARVALHO, 1998).

\subsubsection{Importância do Estudo em relação às Políticas Públicas}

Ao analisar políticas públicas e programas governamentais a partir da perspectiva de gênero, pretende-se verificar em que medida iniciativas do Estado têm contribuído, ainda que de forma incipiente e embrionária, para modificar O padrão de submissão e vulnerabilidade das mulheres, profundamente arraigado na sociedade brasileira, considerando-se as conquistas de direitos efetivados pelas mulheres ao longo da história. 
A constituição das mulheres como sujeito político deu-se inicialmente por meio de sua mobilização em torno da democratização do regime e de questões que atingiam trabalhadores e trabalhadoras urbanos pobres em seu conjunto, tais como baixos salários, elevado custo de vida e questões relativas à inexistência de infra-estrutura urbana e ao acesso precário a serviços coletivos, manifestação 'perversa' no espaço urbano do modelo de desenvolvimento capitalista adotado no país, caracterizado pela articulação entre "crescimento e pobreza". Os movimentos sociais urbanos organizavam-se em torno de questões como falta de água e de saneamento nas periferias das cidades e de reivindicações por equipamentos coletivos como escolas, creches e postos de saúde.

Ao mesmo tempo que denunciavam desigualdades de classe, os movimentos de mulheres - ou as mulheres nos movimentos - passaram também a levantar temas específicos à condição da mulher como direito a creche, saúde da mulher, sexualidade e contracepção e violência contra a mulher.

Sob impacto desses movimentos, na década de 80 foram implantadas as primeiras políticas públicas com recorte de gênero. Tal é o caso da criação do primeiro Conselho Estadual da Condição Feminina, em 1983, e da primeira Delegacia de Polícia de Defesa da Mulher, em 1985, ambos no Estado de São Paulo. Essas instituições se espalharam a seguir por todo o país. Ainda em 1985 foi criado o Conselho Nacional dos Direitos da Mulher, órgão do Ministério da Justiça (SAFFIOTI, 1994). Foi também a mobilização de mulheres que levou à instituição do Programa de Assistência Integral à Saúde da Mulher (PAISM), em 1983 (CARRANZA, 1994).

A Constituição de 1988 também reflete a mobilização de mulheres. Organizadas em torno da bandeira Constituinte pra valer tem que ter palavra de mulher, as mulheres estruturaram propostas para a nova Constituição, apresentadas ao Congresso Constituinte sob o título Carta das Mulheres Brasileiras. Várias propostas dos movimentos - incluindo temas relativos a saúde, família, trabalho, violência, discriminação, cultura e propriedade da terra foram incorporadas à Constituição (COSTA, 1998).

A formulação de políticas públicas dirigidas às mulheres, visando ao estabelecimento da igualdade social entre elas e os homens, exige que se conheça, a fundo, a história das relações entre eles - os indivíduos - e elas - as subordinadas. Os estudos feministas 
caminharam tanto, que já não se pode aceitar meramente uma análise dos papéis sociais, desempenhados por eles e por elas. O conhecimento das origens deste "patriarcado moderno (...) fraternal, contratual (...), que estrutura a sociedade civil capitalista (PATEMAN, 1993), é fundamental para o domínio dos meandros da sociedade como um todo e, por conseguinte, para capacitar a todos a participar desta empreitada e/ou a entender transformações que afetarão, profundamente, suas vidas. Urge que a educação, em todos os níveis, seja oferecida ao povo brasileiro, com recorte de gênero e enfoque democrático, ou seja, em direção à igualdade social entre homens e mulheres, brancos e negros, abastados e pobres. Em si mesmo, este enfoque deve integrar o próprio ato educacional interessado na construção de uma democracia plena.

Apesar da inegável importância do assunto, a criminalidade feminina nunca mereceu senão notas de rodapé nas obras criminológicas e jurídicas. É o que lembram Frinhani e Souza:

No Brasil, os dados que tratam da criminalidade feminina são poucos e pouco reveladores da real dimensão deste fenômeno social. Poucos são os estudos que tratam da criminalidade feminina em relação à criminalidade geral (FRINHANI e SOUZA, 2002, p.61)

$\mathrm{Na}$ história do pensamento, as idéias de crime e criminoso têm sido antropocêntricas, isto é, a construção dos conceitos e postulados teóricos deita alicerces numa ideologia masculinizada, que leva em conta uma visão masculina do mundo. Mesmo as pesquisas de campo apenas subsidiariamente colocam a mulher como elemento de interesse investigativo. Mas justamente através das pesquisas empíricas, com destaque para a temática prisional, que passaram a detectar, nas últimas décadas, uma instigante modificação da participação feminina nas mais diversas modalidades de episódios criminógenos, iniciou-se um processo de segmentação dos estudos em torno do envolvimento da mulher com a criminalidade. Até então, o estudo de uma criminalidade que se pudesse considerar tipicamente feminina se baseava em estereótipos, "pré-conceitos" e representações sociais bem específicas (VOEGELI, 2002).

É tido como assertiva correta entre os criminólogos que a criminalidade feminina, em números absolutos, é significativamente menor em comparação com a masculina. Em geral, as opiniões dos analistas vêm apoiadas em dados estatísticos. No sistema prisional, as mulheres compõem algo em torno de $4 \%$ da população carcerária brasileira. Por outro lado, acredita-se que as cifras negras na criminalidade feminina podem ser bem maiores do que aquelas atualmente divulgadas, o que diminuiria o abismo existente entre ela e a de perfil 
masculino. Os dados estatísticos de diversas pesquisas e também do Ministério da Justiça, no tocante ao sistema prisional brasileiro, apontam que a presença da mulher na última etapa do sistema de justiça criminal continua de menor repercussão. Os delitos relacionados a entorpecentes (tráfico, associação para o tráfico etc.) e também de crimes interpessoais (homicídio, seqüestro, roubo etc.). (Ministério da Justiça, 2008).

A intenção desse TCC é contribuir para a formulação de políticas públicas com o recorte de gênero e permitir uma análise que situa a questão de gênero, e suas implicações, nas mais distintas instituições sociais - aqui a instituição analisada será o CAJE. Em contrapartida, visa ainda analisar os desdobramentos que salientam como a categoria de individuo tende a apagar ou secundarizar a diferença sexual/de gênero, acabando por utilizar a suposta igualdade que funda a configuração moderna da cidadania ocidental capitalista por individualização; isso firma-se na imputação da indiferenciação e nem sequer faz uma reflexão sobre a condição da mulher na sociedade burguesa, ou seja essas adolescentes sentenciadas assistem à uma instituição com premissas de uma suposta igualdade, pouco politizado e com uma demanda interpretativa e nada propositiva.

\section{REFERENCIAL TEÓRICO}

\subsection{A Concepção da Categoria Gênero}

\subsubsection{O que é Gênero? - Suas Origens e Desdobramentos}

O conceito gênero, diferentemente do que se imagina, não foi formulado por uma mulher, quem foi o primeiro a conceituar gênero foi Robert Slotte ${ }^{15}$ (1968). O conceito, todavia não prosperou. Somente em 1975 com o artigo "The Traffic Womem"16 de Gayle Rubin, seus estudos frutificaram dando origem a uma nova postura chamada perspectiva de gênero (SAFFIOTI, 2004). RUBIN (1975) argumenta que as relações sociais são expressas

\footnotetext{
${ }^{15}$ A rigor, embora não haja formulado o conceito de gênero, Simone de Beauvoir mostra que só lhe faltava a palavra, pois em sua celebre frase - "ninguém nasce mulher, mas se torna mulher" - estão os fundamentos do conceito de gênero. Lutando contra o essencialismo biológico - "A anatonima é o destino" - enveredou pela ação da sociedade na transformação do bebê em mulher ou em homem. Foi conseguinte a precussora do conceito de Gênero (SAFFIOTI, 2004).

16 "Traffic in Women" é, sobretudo, lembrado (e, a partir de finais da década de 1980, também criticado) por ter traçado a distinção entre sexo e gênero, oferecendo elementos para a elaboração do conceito de gênero. As abordagens feministas, refletindo sobre a subordinação das mulheres, foram pioneiras no questionamento à relação direta e naturalizada entre reprodução e gênero, e um de seus efeitos é confundir sexualidade e gênero. Mas, no decorrer das décadas, e paralelamente ao vertiginoso crescimento dos estudos de sexualidade nos estudos sobre saúde reprodutiva, incluindo aqueles voltados para a AIDS, essas reflexões instigantes parecem ter se diluído. O "Traffic" foi central nesses questionamentos.
} 
em um sistema sexo/gênero cuja gramática age segundo a qual a sexualidade biológica é transformada pela atividade humana que cria uma sistemática de hierarquias que fazem a manutenção da diferença entre a necessidade e a capacidade humana de organizar de forma opressiva, empiricamente, os mundos sexuais imaginários ou reais que cria.

Com esse artigo, Rubin inaugura a porta de entrada para o caminho exploratório acerca das representações sociais do masculino e do feminino como a elaboração social do sexo (SAFFIOTI, 2004), o que gerou reflexões sobre a dicotomia sexo gênero, um situado na biologia, outro, na sociedade, na cultura. Um grande contingente de feministas, mulheres e homens, têm combatido o raciocínio dualista.

A postura adotada aqui consiste em considerar sexo e gênero uma unidade, uma vez que não existe uma sexualidade biológica independente do contexto social em que é exercida. Naquele momento Rubin, abre caminho também para separar as duas dimensões subsumidas no conceito de patriarcado ${ }^{17}$. O que vale a pena ser ressaltado é o uso errôneo desse conceito, numa contradição com sua própria crença de que todas ou quase todas as sociedades conhecidas apresentam/apresentaram a subordinação feminina, o que na verdade acontece é a supervalorização do macho em uma cultura falocêntrica ${ }^{18}$, patriarcal e sexista $^{19}$.

O conceito gênero no Brasil alastrou-se rapidamente na década de 1990, em decorrência da divulgação do artigo de Joan Scott (1983, 1988). O artigo analisa como os dicionários adotados mundialmente, exemplo “The Consice Oxford Dictionary”, define a idéia de gênero como categoria analítica. Scott desconstrói o gênero como mero descritivo do sexo masculino e feminino, mas o pontua como uma categoria social e histórica co-existindo elementos que vão desde símbolos culturais, passando por conceitos normativos e

\footnotetext{
${ }^{17}$ Dominação masculina convertida nas relações sociais com o vetor $\rightarrow$ Exploração Dominação (Saffioti, 2004). Explicação mais detalhada no item 2.1.4 Gênero, Patriarcado e Sexismo.

${ }^{18}$ A centralidade do falo para a vida social da mulher, que culmina na figura do filho homem - e a posição masculina primaria, tanto para homens como para mulheres, ou seja é o reconhecimento efetivo pelo discurso freudiano do valor superior da figura do homem em relação `a da mulher. Essa "superioridade ontológica" é decorrente do lugar primordial que o homem já ocupa já que é o detentor do falo (Birman, 2001).

${ }^{19} \mathrm{O}$ sexismo é a discriminação ou tratamento indigno a um determinado gênero, ou ainda a determinada identidade sexual. Para a Psicologia, o Sexismo é um regime cultural onde um sexo tenta se sobrepor ao outro. Existem duas assunções diferentes sobre as quais se assenta o sexismo: a) Um sexo é superior ao outro; b) Mulher e homem são profundamente diferentes (mesmo além de diferenças biológicas), e essas diferenças devem se refletir em aspectos sociais como o direito e a linguagem. Em relação ao preconceito contra mulheres, diferencia-se do machismo por ser mais consciente e pretensamente racionalizado. Nesse caso o sexismo muitas vezes está ligado à misoginia(ódio às mulheres) (Saffioti, 2004).
} 
instituições sociais, ate a subjetividade. A própria Scott percorreu meandros do gênero em sua forma substantiva, enquanto categoria histórica. Com efeito, sua primeira proposição estabelece:

\begin{abstract}
“... gênero é um elemento constitutivo das relações sociais baseadas nas diferenças percebidas entre os sexos (segunda: e gênero é um modo primordial de significar relações de poder)". (...) E tem como conseqüência que, "...gênero envolve quatro elementos interrelacionados: primeiro, símbolos culturalmente disponíveis que evocam representações múltiplas (e freqüentemente contraditórias) (...) Segundo, conceitos normativos que estabelecem interpretações dos significados dos símbolos, que tentam limitar e conter suas possibilidades metafóricas. (...) Esta espécie de análise deve incluir uma noção de política e referência a instituições e organizações sociais - o terceiro aspecto das relações de gênero. (...) O quarto aspecto do gênero é a identidade subjetiva" (SCOTT, 1988, p.42-44).
\end{abstract}

No mesmo artigo, Scott pontua o vetor da dominação-exploracão, baseada da hierarquia entre homens e mulheres na estrutura de poder, ou seja, sinaliza a importância do gênero como uma maneira primordial de significar relações de poder e a recorrência deste elemento, na tradição judaico-cristã e na islâmica, para também compreender a vida social em seus modos de perceber e organizar, concreta e simbolicamente as representações humanas.

Nesse período de profusão de idéias feministas, SCOTT (1990) dá o pontapé inicial quando categoriza gênero como estrutura de análise para o mundo cientifico, que fica obscurecido por argumentos ambíguos na direção da igualdade ou da desigualdade entre as categorias de sexo/gênero. É necessário pontuar como o gênero é visto ora como capaz de colorir toda a gama de relações sociais, ora como um mero aspecto dessas relações, assim fica difícil dimensionar sua importância e sua capacidade de articular relações de poder, firma-se como um ponto fundamental para o estabelecimento e da manutenção da igualdade e da desigualdade.

Cabe mencionar também que quem lida com o gênero em uma perspectiva feminista contesta a dominação-exploracão masculina como uma estratégia de luta para a construção de uma sociedade igualitária. (SAFFIOTI, 2004). 
Outra consideração pertinente na categorização do conceito gênero como teoria de construção histórica contemporânea é o que Judith Butler ${ }^{20}$ em Problemas de Gênero: Feminismo e subversão da identidade faz:

“... O Gênero nem sempre se constituiu de maneira coerente ou consistente nos diferentes contextos históricos, ou seja o gênero estabelece intersecções com modalidades raciais, classistas, étnicas, sexuais e regionais de identidades discursivamente constituídas. Temos a tendência de considerar natural o que e masculino e o feminino. Para nos são evidencias incontornáveis de ordem biológica. As figuras do homem e da mulher, no entanto não se restringem absolutamente a condição do ser macho e do ser fêmea, mas ultrapassa esses limiares, com efeito direito de construções sociais e culturais de grande complexidade, modeladas por regras e códigos simbólicos meticulosos...”(BUTLER, 2003, p.75)

Assim afirma-se a variedade do que é ser mulher e que a categoria gênero discute em cada contexto, ao mesmo tempo em que se reconhece certas constâncias da condição feminina, assinalando a peculiaridade e especificidade que as mulheres possuem do mundo contemporâneo e destaca-se um descompasso entre padrões culturais tradicionais e a vigência das regras da postulação da igualdade nos marcos do capitalismo ${ }^{21}$.

A simbologia do individualismo opera em determinadas instâncias, enquanto em outras parece sucumbir. Dilema maior desse sistema ideológico que propala o igualitarismo, mas cuja realidade esta eivada de assimetrias constitutivas. Mas e justo no âmbito desse modo de significar o mundo - primazia do individuo que possui uma lógica anterior "a do próprio social - que faz emergir o questionamento dos papeis de gênero, do Sistema Binário e da Identidade de Gênero. (BUTLER, 2003).

\footnotetext{
${ }^{20}$ Judith Butler é uma feminista que contribuiu para a construção da teoria que criou elos entre as comunidades GLBTTT, em torno de idéias como performance e subversão de gênero ou feminismo sem a categoria de mulheres. Seu primeiro livro de impacto foi Gender Toubles, 1990, publicado no Brasil como Problemas de Gênero, em 2003.

${ }^{21}$ Marx e Engels, autores referencia no que corresponde a compreensão do modo de produção capitalista e formuladores de teorias para a superação das relações de exploração da classe operaria, não escreveram especificamente sobre as questões femininas, o que existem são idéias soltas em seus textos, com pouco desenvolvimento e algumas vezes contraditórias por negarem a categoria gênero nas relações sociais e acreditarem que toda e qualquer opressão seria resolvida depois que instituída a Revolução, materializada pela ditadura da classe operaria em detrimento da classe burguesa. No legado feminista marxista, autoras como Alexandra Kollontai e Samora Machel afirmavam em seus estudos que as mudanças especificas da sociedade com relação ao gênero se resolveria após a Revolução, mantendo a idéia original de Marx e Engels.
} 


\subsubsection{Dicotomia Sexo/Gênero: Papéis Sexuais, Sistema Binário, Identidade e Diferença de Sexo/Gênero}

A partir dos anos 1970 binômio sexo/gênero ganhou maior atenção por parte de pesquisadores(as) e estudiosos(as) que entendiam o sexo como representando a anatomia e a fisiologia (natureza), enquanto o gênero representaria as forças sociais, culturais, políticas e institucionais que moldam os comportamentos e as constelações simbólicas sobre o feminino e o masculino. Assim, questionavam os significados psicológicos e culturais das diferenças, não o domínio do sexo físico. No entanto, novas abordagens, hoje identificadas com as correntes pós-modernas feministas, passaram cada vez mais a desconfiar de oposições binárias como natureza/cultura e sexo/gênero.

A noção de gênero é entendida aqui como relações estabelecidas a partir da percepção social das diferenças biológicas entre os sexos (SCOTT, 1995). Essa percepção, por sua vez, está fundada em esquemas classificatórios que opõem masculino/feminino, sendo esta oposição homóloga e relacionada a outras: forte/fraco; grande/pequeno; acima/abaixo; dominante/dominado (BOUDIEU, 1999). Essas oposições são hierarquizadas, cabendo ao pólo masculino e seus homólogos a primazia do que é valorizado como positivo, superior. Essas oposições/hierarquizações são arbitrárias e historicamente construídas.

A divisão entre os sexos parece estar na ordem das coisas(...)
ela está presente, ao mesmo tempo, em estado objetivado (...)
em todo o mundo social, e em estado incorporado, nos corpos
e nos hábitos dos agentes, funcionando como sistemas de
esquemas de percepção, de pensamento e de ação (BORDIEU,
1999, p. 17).

Entender as relações de gênero como fundadas em categorizações presentes em toda a ordem social, permite compreender não somente a posição das mulheres, em particular, como subordinada, mas também a relação entre sexualidade e poder. A sexualidade, longe de ser um "domínio da natureza" é considerada aqui como um "fato social" enquanto condutas, como fundadora da identidade e como domínio a ser explorado cientificamente (MURARO e BOFF, 2002). A sexualidade é perpassada por aqueles esquemas de classificação, fundados na oposição e hierarquização entre masculino/feminino, a partir da oposição entre ativo/passivo, o que estabelece uma ligação entre sexualidade e dominação: as imagens, o vocabulário e as significações mobilizadas em cada sociedade para evocar as relações sexuais são, em todos os lugares, utilizados para dizer igualmente a dominação de sexo em geral (PENA, 1991) 
As práticas cotidianas de gênero, de ser homem ou de ser mulher não estão determinadas nem pela genitalidade, nem pelos códigos de sexualidade. O gênero nem é natural, sendo uma criação histórica e cultural, nem está preso completamente a uma ordem dominante de prescrições. A conceituação Gênero, enquanto possibilidade de "entender processos de construção das práticas das relações sociais, que homens e mulheres desenvolvem/vivenciam no social" (LAVINAS, 2000), tem redundado em algumas questões que precisam ser melhor definidas. Em primeiro lugar o conceito tem uma história, pois ao longo dos séculos, as pessoas utilizaram de forma figurada "os termos gramaticais para evocar os traços de caráter ou os traços sexuais” (SCOTT, 1995). Assim, já em 1878, Gladstone, citado por Scott, afirmava que "Atena não tinha nada do sexo além do gênero, nada da mulher além da forma"

Segundo Mary Garcia Castro a dinâmica entre classe e gênero na America Latina, são definidas por categorias que se entrelaçam, mas o gênero assim como a relação étnicoracial se expressa/realiza em uma sociedade de classe, em uma dinâmica - gênero, geração e raça, ou seja, é necessário 'sexualizar' as classes sociais, considerando que as práticas de vivências das relações de classe passam por ser mulher ou ser homem, como também passam por ser negro/negra ou branco/branca e como ser jovem ou velho/velha idosos(as) clivagens que podem tanto qualificar como bloquear a identidade quer de classe quer de gênero, o que personifica nas construções dos papeis sociais citados abaixo:

\footnotetext{
* mulher = mãe, procriadora, terna, altruísta, abnegada, afetiva, débil, dependente, frágil, cuidadora, vaidosa.

* homem = agressivo, ativo, egoísta, com iniciativa, provedor econômico, forte, capaz de tomar grandes decisões, independente.
}

Recentemente as feministas americanas começaram a utilizar a palavra Gênero no sentido literal, como uma forma de entender, visualizar e referir-se à organização social da relação entre os sexos. Eram tentativas de resistência ao determinismo biológico implícito, por parte destas feministas, presente no uso dos termos como sexo ou diferença sexual. Na verdade queria-se enfatizar o caráter fundamentalmente social das distinções baseadas em sexo. Conforme assinala SCOTT (1995), citando Davis, "nosso objetivo é descobrir o leque de papéis e de simbolismos sexuais nas diferentes sociedades e períodos, é encontrar qual 
era o seu sentido e como eles funcionavam para manter a ordem social ou para mudá-la" (SCOTT, 2005, p.72).

Maria Gabriela Hita em "Igualdade, Identidade e Diferença[s]: Feminismo na reinvenção de sujeitos afirma que muitos estudos de teóricas feministas como Laurentis, Scott, Haraway, Butler foram progressivamente desmantelando a idéia que sustentava o lado supostamente natural/biológico do par sexo/gênero, compreende agora na construção do que seria uma "identidade feminina" 22 como conseqüência direta do movimento diluente de pares dicotômicos. O que passa a ser recorrente no feminismo atual o questionamento à distinção que se fazia entre categorias como "sexo" (tido como o aspecto biológico) e "gênero" (tido como o aspecto cultural), e essa nova forma de pensar a realidade social resgata a centralidade da categoria Diferença, ou seja para o referencial de analise feminista é necessário afirmar as diferenças e especificidades de gênero, isto é, o direito à "diferença" da mulher em relação ao homem, de modo a reivindicar não apenas o direitos universais, mas também os direitos específicos de mulheres.

Sexo e gênero são intercambiáveis para BUTLER (2003), pois ambos estão imbricados nas marcas dos constructos sociais. Dizer que o gênero existe é pensar e aceitar as normas culturais que governam a interpretação dos próprios corpos. Portanto Sexo e gênero não são características descritivas nem prescritivas e tampouco possuem uma estabilidade natural. Então não há identidade de gênero anterior as suas performances. Só o que há é o disciplinamento do desejo que direciona a 'lógica' de uma atração binária dos 'opostos'. Se for desarticulado o caráter natural do binarismo sexual, os sexos/gêneros podem manifestar-se performativamente pois o corpo já não será mais um dado biológico irredutível e sim um aporte subsidiário

Do século XIX até aproximadamente os anos 60 do século XX teria predominado a teoria da "Igualdade" associada a ideais revolucionários que defendiam a noção de um

\footnotetext{
${ }^{22}$ A representação das identidades tanto do feminino quanto do masculino seguem uma política e lingüística já que apresenta duas opções (homem e mulher), nas quais os sujeitos devem conformar-se. Somente os sujeitos construídos/conformados de acordo com as normas seriam representados politicamente. Por isso as mulheres não devem pleitear o ingresso na categoria de sujeito (já que, como Foucault, acredita que o poder cria os sujeitos que o vêm representar) e sim transgredir os critérios dessa regulação política e de representação. No entanto, reconhece a necessidade estratégica de manter a categoria mulheres, por imperativo da política feminista (BUTLER, 2003).
} 
sujeito universal, onde preocupava superar distinções de classe e não de $\operatorname{sexo}^{23}$. Os ideais burgueses de Igualdade, Fraternidade e Liberdade no período histórico Iluminista foram adotados como as bandeiras da classe trabalhadora e de correntes marxistas em geral, que privilegiam a categoria classe e as relações de poder imbricadas na sociedade e por vezes acabam menosprezando outras categorias como gênero e raça por exemplo, em lutas e conquistas (HITA, 2002) .

\begin{abstract}
"Certa vez Marx perguntou: 'O que é um escravo negro? Um homem de raça negra. Esta explicação é tão boa quanto a outra: um negro é um negro. Ele se torna um escravo negro somente em certas relações. Poderíamos parafrasear Marx: $\mathrm{O}$ que e uma mulher subordinada?Uma fêmea da espécie humana. Esta explicação e tão boa quanto a outra: a mulher e uma mulher. Ela se torna uma domestica, uma esposa, um objeto, uma coelhinha, uma prostituta, ou uma ditafone humano somente em certas relações." (RUBIN apud VIEZZER, 1991 p. 22)
\end{abstract}

O esquema interpretativo marxista que materializa o viés interpretativo classista é bastante difundido, sendo a obra de referencia quase obrigatória A origem da família, da propriedade privada e do Estado de Friedrich Engels (ENGELS, 1974). Nela o autor se utiliza de obras evolucionistas sobre a seqüência histórica das formas de família e de casamento, basicamente as de Morgan e Bachoffen. Este último em Das Mutterrecht (1861) propõe um esquema evolutivo que vai da promiscuidade, quando reinaria o caos sexual, ao patriarcado, sendo a fase matriarcal uma etapa intermediaria entre as duas. Segundo Engels todas as sociedades conhecidas apresentaram uma divisão do trabalho baseada no sexo e na idade (a que ele chama de "natural"), mas, ressalta isto não implicava desigualdade ou opressão sexual. Esta só teria origem na história com o aparecimento da propriedade sobre os bens de produção e das classes sociais. Assim nas sociedades "primitivas" ${ }^{24, " ~ o n d e ~ o ~}$ parentesco e a transmissão de bens traçados por linha materna, as mulheres são o foco central da comunidade e sua contribuição para a produção é visível e valorizada. Até mesmo autoras feministas reconhecem que a interpretação das origens da subordinação sexual na sociedade

\footnotetext{
${ }^{23}$ Heilborn, Maria Luiza: Gênero e Condição Feminina - Uma abordagem Antropológica. Rio de janeiro, IBAM/UNICEF/UFRJ 1991.

${ }^{24}$ A expressão "primitiva”, adotada neste TCC, foi utilizada por Engles em seu livro. Preferi problematizar a expressão usada por ele porque o termo "primitivo"pode, para um leitor(a) despreparado(a), assumir uma conotação pejorativa, o que certamente não foi a intenção do autor. Ambas as expressões referem-se às civilizações antigas que habitaram nosso mundo (Grega, Indiana, Chinesa, etc.), bem como a povos que ainda coexistem conosco, mas que foram capazes de preservar suas tradições de origem, sem hierarquizar entre "primitivos" e ou "civilizados".
} 
de classes padece de um acentuado viés economicista. Verene Solche por exemplo afirma de maneira coerente com o primado marxista da propriedade como flucro da desigualdade:

\begin{abstract}
"a domesticação da mulher é em definitivo um produto do controle do homem sobre a sua sexualidade e capacidade reprodutora da mulher devido ao interesse de perpetuar o acesso desigual aos meios de produção" (SOLCHE, 2003, p. 45).
\end{abstract}

\title{
2.1.3 Gênero e Poder
}

No que concerne a relação gênero e poder, teóricas feministas, como Scott e Laurentis, buscam inspiração no filósofo francês Michel Foucault, que entende as relações de poder como constelações dispersas de relações desiguais constituídas pelos discursos nos campos de forças sociais. Assim é que, de acordo com a concepção foucaultiana de poder, no interior desses processos e estruturas, abrem-se as perspectivas para a constituição de um agente humano como resultante da tentativa de construção de uma identidade, uma vida, um conjunto de relações, uma sociedade permeada por limites e dotada de uma linguagem que, por sua vez, além de ser conceitual, estabelece fronteiras e apresenta a alternativa da negação, da resistência, de reelaboração, das estratégias de reinvenção metafóricas e imaginativas. (BUTLER, 2003)

Coexistem com as análises Foucaultianas, teóricas feministas-socialistas ${ }^{25}$ que discutem o gênero referenciando a singularidade de casos das sociedades de classes no mundo contemporâneo, e torna-se praticamente impossível não articular nas relações de poder: as classes sociais. A gênese das classes sociais seguindo a concepção de origem marxista não é a mesma que a do gênero. O termo classe social é desnaturalizado pelo marxismo, que o integra como conceito, isto é, como uma construção que é parte de uma teoria, de um corpo de conhecimento que pretende não somente explicar a acumulação de capital, a exploração da força de trabalho - a classe proletária - mas principalmente informar a transformação de tal realidade. Nos escritos de Marx, menos que a definição seria, propriamente, de classe, as referências são as lutas de classes. Classe seria, portanto, uma categoria relacional, estando cada classe definida por sua relação com as demais, ou seja, nas

\footnotetext{
${ }^{25}$ Para as teóricas feministas-socialistas, quando se fala de gênero e classe, pontua-se a divisão sexual do trabalho "e uma categoria nuclear que daria um carater materialista `a teoria sobre patriarcado. Identificaria as relações de desigualdade entre homens e mulheres. Por divisão sexual de trabalho se entende, por um lado, a exclusão das mulheres de participar do processo produtivo e, por outro lado, segundo o diferente posicionamento de homens e mulheres na forca de trabalho (...)
} 
relações sociais em que se enfrentam interesses, hierarquias de poder, antagonismos (CASTRO, 2000).

Heleieth Saffioti em Gênero, Patriarcado e Violência (2004) evidencia que as duas categorias gênero e classe têm historias distintas, datando o gênero do inicio da humanidade, há cerca de 250-300 mil anos, e sendo as classes sociais propriamente ditas um fenômeno ligado ao capitalismo, e mais propriamente, a constituição da determinação industrial deste modo de produção, ou seja, a Revolução Industrial. Se, como sistema econômico, ele teve inicio no século XVI, só se torna um verdadeiro modo de produção com a constituição de sua dimensão industrial, no século XVIII. Quando se consideram os embriões de classe, pode-se retroceder as sociedades escravocratas antigas. Mesmo neste caso, as classes sociais têm uma historia muito mais curta que o gênero. Desta forma, as classes sociais são desde sua gênese, um fenômeno engengrado.

Por sua vez, uma serie de transformações no gênero são introduzidas pela emergência de classes. Para amarrar melhor esta questão, precisa-se acrescentar o racismo. $\mathrm{O}$ nó (SAFFIOTI, 2004) formado por essas três contradições apresenta uma qualidade distinta das determinações que o integram. Não se trata de somar racismo + gênero + classe social, mas de perceber a realidade compósita e nova que resulta desta junção. Como afirma Kergoat:

\footnotetext{
“...conceito de superexploração torna-se insuficiente para dar que os fenômenos de discriminação não são somente quantitativos, mas também conta da realidade, já qualitativos (os movimentos de desqualificação/super-qualificação não são mais ou menos fortes segundo os sexos, eles caminham em sentidos diferentes): a divisão técnica e social do trabalho justapõe-se muito estreitamente à divisão sexual do trabalho". (...) “... o universo do trabalho das operárias formam um sistema no qual capitalismo e patriarcado se substituem (trabalham alternadamente) para explorar dominando e dominar explorando; portanto, sistema integrado, no qual as barreiras sociais não são praticamente nem passíveis de derrubada nem mesmo contornáveis pelas mulheres operárias. Mas, seria falso crer que as mulheres operárias são totalmente oprimidas e dominadas" (KERGOAT, 1978, p.77).
}

Como afirma KERGOAT (1978), o conceito de super exploração não dá conta da realidade, uma vez que não dá conta da realidade, visto que não existem apenas discriminações quantitativas, mas também qualitativas. Uma pessoa não é discriminada por 
ser mulher, trabalhadora e negra. Efetivamente, uma mulher não é duplamente discriminada, porque, além de mulher, é ainda uma trabalhadora assalariada. Ou, ainda, não é triplamente discriminada. Não se trata de variáveis quantitativas, mensuráveis, mas sim de determinações, de qualidades, que tornam a situação destas mulheres muito mais complexas. Cabe lembrar aqui que essas definições dizem respeito às representações do masculino e do feminino, e do uso simultâneo do conceito de gênero com o patriarcado.

Não seria justo usar um texto antigo de Kergoat, no qual ela expõe uma idéia ainda válida, mas em que utiliza o conceito - patriarcado - que abandonou. Com efeito, grande parte, talvez a maioria, das (os) feministas francesas (es) usam a expressão relações sociais de sexo em lugar de relações de gênero. Eram/são um bastião de resistência contra a penetração, no francês, de uma palavra - gênero - com outro significado. Na tentativa de valorizar a expressão relações sociais de sexo, não considera incompatíveis os conceitos de gênero e patriarcado:

“...Pode ser útil lembrar que o movimento feminista francês, diferentemente do que se passou em outros países, se definiu, de início, em parte no interior e/ou em oposição aos partidos políticos de esquerda e foi profundamente marcado pelo marxismo como teoria de referência. Vem daí um vocabulário análogo: modo de produção doméstico, relações sociais de sexo, classe de sexo (GUILLAUMIN, 1978) etc. Mas, não se_esgota nisso. De fato, a redução da análise em considerar somente a variável do sexo é muito mais difícil com o conceito de relações sociais de sexo, termo que implica, necessariamente, uma certa visão da sociedade e que elimina outras, por exemplo: é difícil falar simultaneamente de relações sociais de sexo e patriarcado, enquanto que a utilização do termo gênero o permite. E mais, 'relação' tem uma conotação de reciprocidade, o que não tem o termo 'gênero': uma categoria só existe em relação a outra. É, portanto, mais difícil 'esquecer', no segundo termo, o grupo social dos homens (KERGOAT, 1996, p. 24-25).

Este pequeno artigo de Kergoat contém, não apenas no excerto utilizado, várias idéias que pedem reflexão. Concorda-se com ela, certamente não pelas mesmas razões, no que tange ao uso simultâneo dos conceitos de gênero e de patriarcado, como se deverá deixar claro posteriormente. Aparentemente, sua recusa do termo gênero está correta. Entretanto, gênero diz respeito às representações do masculino e do feminino, e estas se inter- 
relacionam. Ou seja, como pensar o masculino sem evocar o feminino? Parece impossível, mesmo quando se projeta uma sociedade não ideologizada por dicotomias, por oposições, mas em que masculino e feminino são apenas diferentes. Lembra-se, aqui, que diferente faz par com idêntico. Já igualdade faz par com desigualdade, que são conceitos políticos (SAFFIOTI, 1997). Assim, as práticas sociais de mulheres podem ser diferentes das de homens da mesma maneira que, biologicamente, elas são diferentes deles. Isto não significa que os dois tipos de diferenças pertençam à mesma instância.

\subsubsection{Gênero, Patriarcado e Sexismo}

O exposto acima permite verificar que o gênero é aqui entendido como uma categoria de analise mais vasta que o patriarcado, na medida em que neste as relações são hierarquizadas entre seres socialmente desiguais, pois o gênero compreende também relações igualitárias. Desta forma, o patriarcado é um caso específico de relações de gênero. De acordo com os estudos de Lerner, a construção do patriarcado precisou de aproximadamente 2.500 anos: de 3100 a.C. a 600 a.C., quando então teria se consolidado. Sua idade é, pois, segundo as evidências encontradas por esta historiadora, de 2.400 anos. Somando-se os dois períodos, têm-se aproximadamente cinco milênios de dominação masculina. Ela examinou dados concretos, mitos e metáforas do antigo Oriente e sua incorporação pela Civilização Ocidental:

“... 1. A apropriação pelos homens da capacidade sexual e reprodutiva das mulheres ocorreu previamente à formação da propriedade privada e da sociedade de classes. Sua transformação em mercadoria repousa, de fato, na fundação da propriedade privada.

2. Os Estados arcaicos eram organizados na forma de patriarcado; conseqüentemente, desde sua origem, o Estado tem um interesse essencial na manutenção da família patriarcal.

3. Os homens aprenderam a instituir dominação e hierarquia sobre outras pessoas por meio de sua prática anterior de dominação das mulheres de seu próprio grupo. Isto veio a se expressar na institucionalização da escravatura, o que teve início com a escravização das mulheres de grupos conquistados.

4. A subordinação sexual das mulheres foi institucionalizada nos primeiros códigos legais e tornada obrigatória pelo inteiro poder do Estado. A cooperação das mulheres com o sistema foi assegurada por vários meios: força, dependência econômica em

relação ao chefe de família masculino, privilégios de classe outorgados a mulheres conformadas e dependentes pertencentes às classes altas e a divisão artificialmente criada das mulheres em mulheres respeitáveis e não-respeitáveis.

5. A classe, para os homens, era e é baseada em sua relação com os meios de produção: os que possuíam os meios de produção podiam dominar aqueles que não os possuíam. Para as mulheres, a classe é mediada por vínculos sexuais a um homem, que lhes dá acesso a recursos materiais. A divisão das mulheres em 'respeitável' (isto é, ligada a um homem) e 'não-respeitável' 
(isto é, não ligada a um homem ou livre de todos os homens) é institucionalizada em leis referentes à cobertura das mulheres com véu.

6. Muito depois de as mulheres terem sido sexual e economicamente subordinadas aos homens, elas ainda desempenham papéis ativos e respeitados na mediação entre humanos e deuses como sacerdotisas, profetisas, advinhadoras e curandeiras. O poder metafísico das mulheres, especialmente o poder de dar a vida, é cultuado por homens e mulheres na forma de poderosas deusas muito depois de as mulheres terem sido subordinadas aos homens na maioria dos aspectos de suas vidas na terra.

7. O destronamento de poderosas deusas e sua substituição por um deus masculino dominante ocorreu na maioria das sociedades do Próximo Oriente em consequiência do estabelecimento de uma monarquia forte e imperialista. Gradualmente, a função de controlar a fertilidade, antes inteiramente desempenhada pelas deusas, é simbolizada por meio do casamento simbólico ou real do deus masculino ou Deus- Rei com a Deusa ou suas sacerdotisas. Finalmente, a sexualidade (erotismo) e a procriação são separadas com a emergência de deusas para cada uma destas funções, e a Mãe-Deusa é transformada em esposa/consorte do Deus chefe masculino

8. A emergência do monosteísmo hebreu toma a forma de um ataque contra os difundidos cultos de várias deusas da fertilidade. No Livro do Gênesis, criação e procriação são atribuídas ao Deus todo-poderoso, cujos epitáfios de 'Senhor' e 'Rei' o estabelecem como um deus masculino, tornando-se a sexualidade feminina um pecado e um mal, quando dissociada da procriação

9. No estabelecimento da comunidade pactuada, o simbolismo básico e o contrato real entre Deus e a humanidade assumem como um dado a posição subordinada das mulheres e sua exclusão do acordo metafísico e da terrena comunidade pactuada. Seu único acesso a Deus e à comunidade sagrada reside em sua função de mães.

10. Esta desvalorização simbólica das mulheres em relação ao divino torna-se uma das metáforas fundantes da civilização ocidental. A outra metáfora fundante é fornecida pela filosofia aristotélica, que assume como um dado que as mulheres são seres humanos incompletos e defeituosos, de uma qualidade inteiramente diversa da dos homens. É com a criação destes dois constructos metafóricos que são construídos nas próprias fundações dos sistemas simbólicos da civilização ocidental, que a subordinação das mulheres passa a ser vista como 'natural' e, conseqüentemente, se torna invisível. É isto que finalmente estabelece o patriarcado de modo firme como uma realidade ${ }^{26}$ e como uma ideologia" (LERNER, 1986, p. 8-10)..."

Portanto, o patriarcado refere-se aos milênios da história mais próxima nos quais se implantou uma hierarquia entre homens e mulheres, com primazia masculina. Tratar esta realidade em termos exclusivamente do conceito de gênero distrai a atenção do poder do patriarca, em especial como homem/marido, "neutralizando" a exploração-dominação masculina. Neste sentido, e contrariamente ao que afirma a maioria das(os) teóricas(os), o conceito de gênero carrega uma dose apreciável de ideologia. E qual é esta ideologia? Exatamente a patriarcal, forjada especialmente para dar cobertura a uma estrutura de poder que situa as mulheres muito abaixo dos homens em todas as áreas da convivência humana. É a esta estrutura de poder, e não apenas à ideologia que acoberta, que o conceito de patriarcado diz respeito.

\footnotetext{
26 “A matriz de qualquer idéia é a realidade... Em conseqüência, imagens, metáforas, mitos, tudo se expressa em formas 'prefiguradas' por meio da experiência passada. (...) O que tento fazer em meu livro é traçar, por meio da evidência histórica, o desenvolvimento das idéias, símbolos e metáforas líderes pelas quais as relações de gênero patriarcais foram incorporadas à civilização ocidental” (p. 10).
} 


\subsubsection{A Reinvidicação às especificidades de Gênero: O Feminismo}

Quando se fala em teoria/movimento/pratica feminista, muitos(as) pensam que se trata de um agrupamento (político e/ou teórico) defensor dos direitos das mulheres, que teria interpretações e explicações consensuais sobre a realidade e sobre as relações de gênero. Geralmente e associado a uma tendência radical daquele movimento dos anos sessenta que saiu às ruas queimando sutiãs! Como pode ser observado na própria trajetória feminista resumida acima, não existiu no passado uma única definição do ser mulher - se é que esta pretensão é possível - seja igual ao homem, como diferente dele, realçando a complexidade da intenção, de tentar definir uma "essência" feminina devido as diferenças existentes entre as próprias mulheres. Existiram no passado, e ainda hoje, diferentes projetos, alguns ate mesmo antagônicos, em função das premissas e imagens sustentadas sobre o ser humano, os gêneros e a sociedade em geral, e o binômio sexo/gênero inspirou inúmeros estudos de gênero a partir da década de 70 e perdura até hoje que são eles: Sexo/Gênero; Privado/Público; Diferença/Igualdade; Subordinação/Autonomia; Ausência/Presença; Objeto/Sujeito (LOURO, 2002).

No mundo ocidental, os anos de 1960 foram marcados pelos movimentos de questionamento dos grandes problemas contemporâneos. Neste sentido, a "Primavera de Praga" colocou a questão da liberdade no mundo do socialismo real. Os estudantes europeus fizeram o "maio" das revoltas para a transformação do ensino; o movimento hippie pregou a liberdade e o respeito à natureza. Ao mesmo tempo, novos questionamentos foram trazidos ao cenário da vida política e acadêmica: as classes sociais, as nações oprimidas, os preconceitos raciais, o mundo marginal tornaram-se objetos das preocupações políticas e das ciências humanas e sociais. Nos Estados Unidos, paralelamente à luta dos negros americanos contra a segregação racial e ao movimento político contra a guerra do Vietnã, ressurgiu o movimento feminista.

"O feminismo contemporâneo, também chamado "novo feminismo", tem como principal inspiração as idéias expressas pela francesa Simone de Beauvoir em seu livro O segundo sexo, publicado em 1949. Nessa obra, a autora examina o desenvolvimento psicológico da mulher e os condicionamentos de sua socialização, que a tornam alienada e submissa ao homem. As mulheres norte-americanas, francesas, suecas, inglesas, italianas se organizaram e saíram às ruas tendo como palavras de ordem "o privado também é 
político", "nosso corpo nos pertence"... Esta nova onda do feminismo tinha como base o fato de que a mulher se descobre [...] e se quer como sujeito de sua vida, o que produz as mais diversas conseqüências políticas, econômicas e culturais. $\mathrm{O}$ feminismo advoga para as mulheres um espaço exclusivo de atuação política e de luta por interesses, percebidos como específicos" (CASTRO, 2000, p.100)

O "novo feminismo" surgido no Brasil nos anos 1970 caracterizou-se por algumas especificidades, que o diferenciava dos Estados Unidos e países da Europa, na década de 1960. As feministas brasileiras tinham os mesmos questionamentos que suas congêneres americanas e européias, como explicita PINTO (2003):

“As feministas traduzem a rebeldia das mulheres na
identificação de sua subordinação e exclusão do poder, e
buscam construir uma proposta ideológica que reverta esta
marginalidade. Sua concreção se dá a partir da construção de
uma prática social que negue aqueles mecanismos, que
impedem o desenvolvimento de uma consciência como ser
autônomo que supere a exclusão. As feministas fazem do
conhecimento e da eliminação das hierarquias sociais seu
objetivo central”. (PINTO, 2003, p.15).

Esse feminismo "brasileiro" se diferenciava na defesa de propostas que não eram específicas da condição feminina, sem assumir posição radical como as que mobilizavam as mulheres daquelas sociedades. Isto se explica fundamentalmente pelas condições políticas em que se encontrava o Brasil, sob uma forte ditadura militar, e marcada por profundas desigualdades sociais. Não havia espaço para um "movimento de liberação das mulheres centrado exclusivamente em questões específicas das mulheres".

A autodenominação feminista implicava, já nos anos 1970, a convicção de que os problemas específicos da mulher não seriam resolvidos apenas pela mudança na estrutura social, mas exigiam tratamento próprio. As questões propriamente feministas, as que se referiam à identidade de gênero, ganharam espaço quando se consolidou o processo de 'abertura' política no país em fins da década de 1970. Grande parte dos grupos declarou-se abertamente feminista e abriu-se espaço tanto para a reivindicação no plano das políticas públicas, quanto para o aprofundamento da reflexão sobre o lugar social da mulher, desnaturalizando-o definitivamente pela consolidação da noção de gênero como referência para a análise.

Outro traço que marca a trajetória particular do feminismo no Brasil, pelo menos quando comparado ao dos países europeus, diz respeito ao próprio caráter dos movimentos sociais no Brasil em sua relação com o Estado. Os movimentos sociais urbanos organizaramse em bases locais, enraizando-se na experiência cotidiana dos moradores das periferias 
pobres, dirigindo suas demandas ao Estado como promotor de bem-estar social (COSTA, BARROSO e SARTI, 1985). Pesquisas etnográficas sobre os pobres urbanos, desenvolvidas nos anos 1980, momento de efervescência do movimento feminista no Brasil, demonstraram que, para as mulheres pobres, a questão ontológica do ser mulher se fundava no valor da família e da localidade e a sexualidade inexistia como uma realidade autônoma, com significação em si. Evidenciava-se o descompasso entre seu discurso e aquele do feminismo que se instituía no Brasil, o que aponta para a relevância social e política de pensar os limites do feminismo em sua perspectiva universalista.

Nos anos 1980 o movimento de mulheres no Brasil era uma força política e social consolidada. Explicitou-se um discurso feminista em que estavam em jogo as relações de gênero. As idéias feministas difundiram-se no cenário social do país, produto não só da atuação de suas porta vozes diretas, mas também do clima receptivo das demandas de uma sociedade que se modernizava como a brasileira. Os grupos feministas alastraram-se pelo país. Houve significativa penetração do movimento feminista em associações profissionais, partidos, sindicatos, legitimando a mulher como sujeito social particular. (OLIVEIRA, 1998)

O saldo positivo de todo esse processo social, político e cultural, o fim da década de 1980, deu-se uma significativa alteração da condição da mulher na Constituição Federal de 1988, que extinguiu a tutela masculina na sociedade conjugal (LIMA, 1998 e OLIVEIRA, 1998.) A ambigüidade da mulher, em face da opressão de que é objeto, começou a emergir mais claramente em torno da questão da violência contra a mulher, no inicio dos anos 90 . (GREGORI, 1993). A visibilidade dos casos de violência doméstica, cometida contra crianças e adolescentes - sobretudo, a partir da instituição do Estatuto da Criança e do Adolescente (ECA) em 1990 -, em que tanto homens como mulheres aparecem como agressores, contribuiu de forma decisiva para mostrar os intrincados problemas nas relações de gênero, afirmando a necessidade de se trabalhar e pensar em termos de identidades que se constituem em relações construídas a partir de referências sociais e culturais específicas.

\subsection{Política de Proteção a Crianças e Adolescentes (Marco Regulatório)}

As referencias jurídicas adotadas como marco regulatório para efetivação dos direitos das crianças e adolescentes e que será referencia do presente trabalho são as seguintes: Convenção Internacional Sobre os Direitos da Criança, as Regras Mínimas das Nações Unidas para a Administração da Infância e da Juventude (Regra de Beijing), Regras 
Mininas das Nações Unidas para e Prevenção da Delinqüência Juvenil (Diretrizes de Riad), da Constituição Federal Brasileira e do Estatuto da Criança e do Adolescentes, especialmente os artigos de 103 a 190. (VOLPI, 1997) ${ }^{27}$

A promulgação da Lei 8069/90 Estatuto da Criança e do Adolescente (ECA) no Brasil, em consonância com as diretrizes aprovadas na Convenção Internacional dos Direitos da Criança, em 20 de novembro de 1989, fez com que o país adotasse uma nova doutrina em relação à formulação e implementação das políticas públicas voltadas para crianças e adolescentes. Pela primeira vez na história constitucional brasileira, foi conferida à criança e ao adolescente a condição de sujeito de direito e de prioridade absoluta, responsabilizando pela sua proteção a família, a sociedade e o Estado.

Anteriormente à elaboração do ECA, as políticas jurídicas e sócio-educativas tinham como pano de fundo a doutrina da situação irregular, na qual o Código de Menores brasileiro era baseado. Naquela época, as políticas não eram dirigidas ao conjunto da população infanto-juvenil, mas apenas aos "menores em situação irregular". Com a promulgação do ECA, houve uma verdadeira transformação paradigmática no plano jurídicolegal, que passou a se basear, especificamente, na definição das medidas sócio-educativas e na doutrina da proteção integral. (Ministério da Justiça, 1998).

Na história recente do atendimento ao adolescente autorxs de ato infracional no Brasil, quatro etapas importantes se destacam:

- 1942-1964. Foi a época do Serviço de Assistência ao Menor (SAM) no qual o modelo de atendimento ao adolescente infrator era do tipo correcional-repressivo. Alguns dos apelidos das unidades de reclusão do SAM eram: "universidade do crime", "famigerado SAM", "sucursal do inferno", entre outros.

- 1964-1990. Com a implantação da Política Nacional de Bem-Estar do Menor (PNBEM), procurou-se fazer um amplo e profundo reordenamento institucional. Foi criada a Funabem, como um órgão da administração indireta, ligado diretamente à Presidência da República, investido de funções normativas e responsável pela coordenação (apoio técnico e financeiro) da nova política em âmbito nacional. Entretanto, na prática, o que se percebeu é

\footnotetext{
${ }^{27}$ Toda essa normativa foi sistematizada por Mario Volpi que na atualidade se personifica como uma referência nos estudos concernentes a Criança e Adolescente.
} 
que PNBEM foi um fracasso em relação à melhoria da atenção direta ao adolescente infrator, e que as unidades de atendimento direto da Funabem mantiveram o mesmo padrão correcional-repressivo herdado do SAM.

- 1990-1995. Com a substituição do Código de Menores pelo ECA, em 1990, foi criado o Centro Brasileiro para a Infância e a Adolescência (CBIA) visando um reordenamento institucional e efetiva melhoria das formas de atenção direta. Por razões políticas, este órgão foi extinto antes que pudesse completar o reordenamento das estruturas herdadas da Funabem.

- A partir de 1995 foi criado o Departamento da Criança e do Adolescente (DCA), órgão integrante da Secretaria Nacional dos Direitos Humanos do Ministério da Justiça, que assumiu a coordenação nacional da Política de Promoção e Garantia dos Direitos da Criança e do Adolescente. (COSTA, 1998)

Foi para romper com a lógica correcional-repressiva e com as práticas de confinamento, ditas de "proteção à infância" que os movimentos sociais, sindicatos, pastorais, partidos políticos e demais grupos e organizações da chamada sociedade civil, no bojo da mobilização pelo fim da Ditadura Militar e pela redemocratização do Brasil, iniciaram ampla mobilização em torno dos Direitos Humanos e de cidadania dos diferentes grupos marginalizados da população brasileira, entre os quais chamados "menores". (PASSETTI e DEL PRIORE, 2002)

À medida em que se pode efetivamente questionar o modelo de assistência até então vigente, tornou-se possível a emergência de novas proposições. Na redação do artigo 227, da Constituição Federal de 1988, o Brasil adotou não apenas a Declaração Universal dos Direitos da Criança, como também o pré-texto da Convenção Internacional da Organização das Nações Unidas (ONU) destes mesmos direitos, que, naquela data, ainda não havia sido apresentado à Assembléia Geral das Nações Unidas. Ao assim proceder, aboliu o Código de Menores de 1979 e, sem eu lugar, em 1990, promulgou o Estatuto da Criança e do Adolescente/Lei 8.069.

A aprovação desta lei gerou intenso otimismo nos militantes de Direitos Humanos, chegando os mais otimistas a afirmarem que o Estatuto representava uma verdadeira 
revolução nas áreas jurídica, social e política, por considerar a criança um sujeito de direitos, pelo princípio da absoluta prioridade no seu atendimento e pela observância de sua condição peculiar de criança em desenvolvimento. Depositava-se grande esperança nos Conselhos de Direitos e Conselhos Tutelares, principalmente pelo princípio da participação popular, também estabelecido no Estatuto.

Decorridos 18 anos de aprovação do Estatuto, no entanto, forçoso reconhecer que as mudanças, até agora obtidas, não têm correspondido ao otimismo esperado. Em nome do equilíbrio fiscal e do cumprimento de metas pactuadas com organismos internacionais, o Brasil vem, progressivamente, diminuindo o gasto com as políticas sociais básicas, inviabilizando, na prática, o cumprimento da Constituição. A crise que se instala, a partir daí, combina desemprego, desesperança, e violência, onde os jovens pobres do sexo masculino têm sido as maiores vítimas, sendo que grande parte das mortes nesta faixa etária acontece por causas externas: acidentes e assassinatos. (ANDES, 2007)

Nesta conjuntura, onde faltam recursos e mecanismos de articulação entre as esferas de poder para a garantia dos direitos sociais ou onde tais recursos não são priorizados frente às exigências de controle fiscal, cresce o número de pessoas favoráveis a um endurecimento da legislação. Divulga-se, insistentemente, como causa do aumento da violência nos grandes centros urbanos, uma suposta impunidade proporcional pelo Estatuto da Criança e do Adolescente, cuja única finalidade seria a de proteger bandidos ${ }^{28}$ - criando na população uma indiferença face ao trágico destino de milhares de jovens pobres, pretos[as] e de condições financeiras subalternas, tanto dos que são executados sumariamente quanto dos que se encontram privados[as] de liberdade.

\footnotetext{
${ }^{28}$ A ausência do respeito aos Direitos Humanos e o modelo perverso de se criminalizar a pobreza tem se perpetuado dentro da sociedade e da estrutura policial brasileira por diversas razões: a herança dos últimos vinte anos do modelo educacional, a falência da política de distribuição de renda, e o modelo policial de visão analógica em um mundo digital; razões essas que evidenciam a intolerância de alguns segmentos da própria sociedade, e apóiam práticas policiais que ajudam a propagar a idéia equivocada de que o ECA que é um braço de execução dos "Direitos Humanos" tem como finalidade "proteger bandido". É difícil admitir, mas existe uma demanda dentro da própria sociedade em prol da prática da violência policial. Se falarmos na visão semiótica de Jean-Claude-Monet, pois a polícia continua sendo uma forma de "controle da violência legítima do Estado", como bem nos ensina Michel Foucault, referindo-se ao meta-modelo "panóptico" em seu livro "Vigiar e Punir" referindo-se que conseqüentemente haveria uma evolução do uso legítimo da força por parte.
} 


\subsection{Brasil e Estatuto da Criança e do[a] Adolescente - ECA}

A doutrina da proteção integral, preconizada pela ONU e inserida na ordem jurídica do Brasil, com o advento da Constituição de 1988, tem procurado combater "toda a forma de negligência, discriminação, exploração, violência, crueldade e opressão". ${ }^{29}$ No contexto social e histórico da sociedade brasileira, o Estatuto da Criança e do Adolescente -ECA ${ }^{30}$ (Lei n º 8.069/1990) veio garantir proteção integral à criança e ao adolescente. Transformou radicalmente a filosofia do antigo Código de Menores - baseada na doutrina da situação irregular - passando a considerar a criança/adolescente como pessoas de direito e em condições peculiares de desenvolvimento.

O ECA é considerado internacionalmente avançado em termos de direitos humanos porque acolhe os princípios de organizações mundiais de proteção à infância e adolescência. Para Madeira (1997), o ECA veio não só ratificar a Declaração Universal dos Direitos da Criança $^{31}$, mas também reconhecer e consagrar a criança e o[a] adolescente como indivíduos e, portanto, cidadãos[ãs]. O Brasil possui uma das mais avançadas legislações de proteção aos jovens, e ainda há muito trabalho a ser feito para torná-la efetiva. Convivemos com o descaso dos governantes pela vida dos jovens e com o abuso das autoridades constituídas, violando os direitos mais elementares que o ECA garante às crianças e aos adolescentes.

A mídia burila suas invectivas, criminaliza os(as) jovens das camadas populares, alcunhando-os(as) de menores e estigmatiza as classes dominadas economicamente chamando-as de carente . A mídia, porém, apenas retrata as representações mais presentes no imaginário da população. Os fóruns nacionais de discussão dos Direitos Humanos ainda estão muito longe de conseguirem tornar efetivas as disposições e protocolos internacionais que o governo federal firmou nos últimos anos. Vale lembrar que o ECA foi aprovado em 1990 como uma grande conquista de movimentos sociais e que só a partir de sua

\footnotetext{
${ }^{29}$ O Estatuto da Criança e do Adolescente, no artigo 5", determina: "Nenhuma criança ou adolescente será objeto de qualquer forma e negligência, discriminação, exploração, violência, crueldade e opressão, punindo na forma da lei qualquer atentado, por ação ou omissão, aos seus direitos fundamentais"

${ }^{30}$ A partir deste momento sempre que se referir ao Estatuto da Criança e do Adolescente, utilizarei a sigla ECA

${ }^{31}$ A Declaração Universal dos Direitos da Criança foi aprovada pela Assembléia-Geral das Nações Unidas com o voto do Brasil, em 20 de novembro de 1959.
} 
promulgação começaram a ser esboçadas políticas públicas voltadas para a criança e o adolescente como sujeitos em suas especificidades, potencialidades e necessidades. (MOREIRA, 2000).

A legislação específica do ECA, normatizou a atuação do Poder Judiciário na defesa deste direitos, atribuiu ao Ministério Público e aos Conselhos Tutelares a promoção e a fiscalização dos mesmos direitos e aos Conselhos Nacional, Estaduais e Municipais a atribuição de formularem as políticas nacional, estaduais e municipais para a criança e o adolescente. Mesmo no ECA, a Justiça da Infância e da Juventude e o juiz continuaram com a possibilidade de intervenção junto à família e à criança nos casos típicos de Direito Processual Civil e Direito Processual Penal, como a guarda, tutela, adoção, investigação de paternidade e maus-tratos.

O juiz passou a ser obrigatoriamente assessorado por uma equipe interprofissional, que no Código de 79 ficava ao seu arbítrio consultar ou não. A equipe técnica (normalmente composta por um psicólogo e um assistente social, no mínimo), tem o mesmo status científico, pois tanto o juiz quanto o psicólogo e o assistente social são bacharéis, mas o ECA ainda fez uma concessão ao Poder Judiciário, atribuindo maior autoridade ao juiz, se entende que ali está configurado um conselho de sentença que impediria definitivamente que as decisões relativas à criança fossem tomadas por uma única pessoa.

O Estatuto da Criança e do Adolescente não traz somente um elenco de novos direitos destinados à infância e à adolescência ${ }^{32}$, tampouco seu grande avanço foi simplesmente a mudança de "menor: objeto de tutela-compaixão-repressão" para sujeito de direitos, mas sim a explicitação de um sistema de garantia de direitos, que também por determinação constitucional, contará com a participação popular.

\footnotetext{
${ }^{32}$ Faz-se necessário a distinção entre criança e adolescente, estabelecida pelo Estatuto e comentada por Ubaldino Calvento Solari que leciona no Instituo Interamericano Del Niño: "A distinção entre "criança" e "adolescente" de dá da seguinte maneira; ambos gozam dos mesmos direitos fundamentais, reconhecendo-se sua condição especial de pessoas em desenvolvimento, o tratamento de suas situações difere, como é lógico, quando incorrem em atos de conduta descritos como delitos ou contravenções pela lei penal. A criança infratora fica sujeita às medidas de proteção no art. 101, que implicam um tratamento através de sua própria família ou na comunidade sem que ocorra privação de liberdade. Por sua vez o[a] adolescente infrator[a] pode ser submetido a um tratamento mais rigoroso que soa as medidas socioeducativas do art. 112 que podem implicar na privação de liberdade.
} 
Em consonância com a norma Constitucional ${ }^{33}$ de natureza garantidora de direito individual o ECA, mesmo considerando o contexto das relações econômicas e sociais de absoluta desigualdade-, introduz nesse universo das desigualdades sociais e vulnerabilidades $^{34}$ das relações humanas as mesmas noções do Direito aplicadas para maiores de idade 18 anos, só que com inovações do conceito de "pena" adotando ato infracional que considera a conduta descrita como crime ou contravenção penal (Artigo 103 do Estatuto da Criança e do Adolescente).

Do ponto de vista das garantias penais, processuais e de execução no sistema da justiça da infância e juventude para autores de condutas penais pode-se afirmar ainda de que maneira preliminar como aspecto primordial, que o Estatuto da Criança e do Adolescente trouxe o status dos[as] adolescentes como sujeitos do processo, e isso os[as] torna detentores[as] de direitos e obrigações próprios do exercício de cidadania plena, observada sua peculiar condição de pessoa em desenvolvimento. (VOLPI 1998).

Hoje, a vigência do ECA é ainda muito precária, mesmo depois de 18 anos de sua promulgação. Recente documento do Unicef denuncia que a maior parte dos princípios do Estatuto não atinge 14 milhões de crianças e jovens com menos de 18 anos no Brasil. Há um milhão de meninos e meninas entre sete e 14 anos fora da escola; 220 mil meninas com até 14 anos trabalhando como empregadas domésticas; 45 mil crianças vivendo em lixões; e 1,9 milhões de jovens analfabetos (ANDI/IAS/UNESCO, 2000). Esses dados refletem como nosso ordemanento social funciona de forma desigual e pode ser explicado por conta da ideologia burguesa ${ }^{35}$ predominante na sociedade brasileira, que discrimina e desconhece esses (as) crianças/adolescentes como sujeitos de direitos. Tratando-os (as) substancialmente como "menores" de forma negativa, designação essa que reforça no imaginário social, a idéia

\footnotetext{
33 Art. 228, da CF: São penalmente inimputáveis os menores de dezoito anos, sujeitos à normas de legislação especial”. Está regra está repetida no art. 27 do Código Penal, de 1984 e elevada a norma Constitucional em 1988,e art. 104 do ECA.

${ }^{34}$ Entende-se aqui por vulnerabilidades o conceito elaborado por Mario Ângelo Silva (2007) em seu artigo "A questão social vulnerabilidades

${ }^{35} \mathrm{O}$ que é chamado de ideologia burguesa, são as verdades da humanidade em seu progresso rumo a emancipação. Então justiça, liberdade, igualdade, fraternidade, universalidade, beleza são idéias verdadeiras. Só são falsas na medida em que na ordem burguesa se apresentam como já realizadas. Karl Marx aponta que a crítica da ideologia nada mais é do que obrigar o mundo a confessar aquilo que ele já é, não estou acrescentando nada, ou seja, na hora em que o mundo se confessa, ele se corrige. E a revolução é essa confissão, em que ele reencontra a sua verdade, expressa na inconsciência da ideologia. A ideologia, portanto, transcende a realidade, está para além da realidade. A realidade está aquém, e a ideologia é falsa porque é uma promessa não cumprida. A crítica da ideologia é uma operação lógico-social, crítico-revolucionária como dizia o Marx , que permite que essa verdade se reencontre consigo mesma. Ou seja, no momento em que aparece, implica necessariamente uma transformação social.
} 
de que todo(a) criança/adolescente é ou será em algum momento um(a) "marginal"36, criando assim o estigma de marginalidade. A mídia, narrativa jornalística dos meios hegemônicos de comunicação, em particular a de estilo policialesco a de corte sensacionalista, tem sido um dos setores responsáveis, frente à opinião pública, pela construção da imagem de crianças e os adolescentes associados a animais, como seres de natureza perversa, nocivos à sociedade, sujeitos sem recuperação ou desumanos, com agressividade incontrolada (GOMIDE, 1990).

\subsection{Adolescentes Infratorxs e a perpetuação do descaso das instituições "ressocializadoras"}

Segundo Mário Volpi em Adolescente e a Lei: "Para entender o direito dos adolescentes, a prática de atos infracionais e sua responsabilização", o Advento do Estatuto da Criança e do Adolescente (Lei 8069, de 13 de julho de 1990) representa um marco divisório extraordinário no trato da questão da infância e juventude no Brasil, visto que o mesmo trouxe uma completa transformação ao tratamento legal da matéria por conta da adoção da Doutrina da Proteção Integral em detrimento dos vetustos primados da arcaica Doutrina da Situação Irregular na qual presidia o antigo sistema marcado por conservadorismos e uma lógica repressora que reproduzia discriminações e situações de vulnerabilidade social.

Sabe-se que a violência contra crianças e adolescentes não ocorre apenas nos órgãos do Estado. No seio da família ${ }^{37}$ e da sociedade, são múltiplas as suas manifestações. Extermínio, exploração sexual, tráfico, prostituição, maus-tratos, abandono, o tráfico internacional e os desaparecimentos, a fome, trabalho penoso, torturas e prisões arbitrárias povoam o universo de milhares de crianças e adolescentes. VOLPI (1999) afirma que: "contrapondo-se a este quadro, parcelas cada vez mais significativas da sociedade mobilizam-se para enfrentá-lo, coibi-lo e modificá-lo".

\footnotetext{
${ }^{36}$ Outros autores, como Cruz-Neto \& Minayo (1994:207), comentam sobre o processo de extermínio na sociedade brasileira. Mostram como os pobres são as principais vítimas deste processo, porque fazem parte de um processo de aniquilamento, de exclusão e de eliminação de grupos sócio-econômicos e culturais considerados "marginais", supérfluos" e "perigosos": "vai se construindo no país um senso comum de que temos um excesso de população (pobre), economicamente supérflua e socialmente sem raízes, candidata à delinqüência e, portanto, sem utilidade numa sociedade competitiva que aspira às riquezas da civilização e à modernidade”.

${ }^{37}$ Segundo Saffioti (1997,p.166) “ Constitui um mito de que homem violento é louco, doente, alcoólatra ... . Mãe que espanca os filhos apresenta qualquer traço de "anormalidade"
} 
No atual momento brasileiro a infração juvenil alcança maior destaque em função de se estar vivenciando uma onda jovem: no ano 2000 existiam 10,7 milhões de adolescentes do sexo masculino e 10,5 milhões do feminino entre 12 e 18 anos incompletos $(12,5 \%$ da população brasileira) (WWWW.Sidra.ibge.gov.ḅ̆, Acesso em Out 2008). A desigualdade econômica e social brasileira dificulta o pleno crescimento e desenvolvimento de milhões de adolescentes, que se vêem aprisionados a comunidades expropriadas, moradias inadequadas, restrições severas ao consumo de bens e serviços, estigmas e preconceitos, falta de qualidade no ensino, relações familiares e interpessoais fragilizadas e violência em todas as esferas de convivência. Adolescentes, principalmente os rapazes, são também vítimas freqüentes da criminalidade urbana. Estão entre os que mais morrem e sofrem violência urbana (ADORNO, 1993 e ZALUAR, 2003).

Ainda dentro desse contexto de fragilidade social juvenil, há um movimento de grupos sociais politicamente poderosos trabalhando para redução da idade penal, mesmo sabendo da gritante contradição que significa o atendimento carcerário e repressor a eles prestado nas unidades de internação. Trata-se de parte do processo de dominação sociopolítica que, na sua hegemonia, cerceia o desenvolvimento integral de crianças e adolescentes, em sua maioria, já discriminados desde o nascimento. (CLAVES, 1999).

A trajetória institucional dxs adolescentes infratorxs em instituições de internamento é violenta e pode ser constatada segundo dados do relatório da avaliação do Departamento Geral de Ações Sócio-Educativas - DEGASE realizado pelo CLAVES em 1999, 60\% dos atuais apenados do sistema penitenciário do Rio de Janeiro são oriundos das instituições de internamento de jovens infratorxs (CLAVES, 2006). Para além da violência institucional, a elevada vulnerabilidade e a tendência à exclusão social são outros aspectos que facilitam a entrada no mundo infrator enfocada por programas de prevenção. Situações de negligência e abandono, pobreza, criminalidade e violência na família, escola, comunidade e sociedade em geral são usuais entre adolescentes em conflito com a lei (VOEGELLI, 2003).

Passados 18 anos da promulgação do Estatuto da Criança e do Adolescente, percebese que apesar das mudanças já ocorridas no panorama jurídico-legal, o atendimento ao adolescente autor de ato infracional em todo país ainda necessita de um amplo e radical reordena mento institucional e de uma efetiva melhoria das formas de atenção direta. Isto 
especialmente no chamado atendimento em regime sócio-educativo. Ou seja, uma reengenharia institucional que permita "tirar do papel" os avanços contidos no ECA em termos de segurança cidadã e direitos fundamentais.

Em relação aos adolescentes em conflito com a lei penal, o ECA determina algumas medidas sócio-educativas que se dividem em dois grupos: a) aquelas não privativas de liberdade (advertência, reparação do dano, prestação de serviço à comunidade e liberdade assistida), e; b) aquelas que submetem o adolescente infrator à restrição ou privação de liberdade (semi-liberdade e internação, com ou sem atividades externas). A aplicação dessas medidas sócio-educativas deve levar em conta não apenas a natureza do ato infracional praticado, mas também, as circunstâncias e as características do indivíduo que o praticou. (Ministério da Justiça, 1998).

No oferecimento e execução de programas de atendimento sócio-educativo em meio aberto e no apoio aos serviços públicos governamentais de atendimento em privação de liberdade, as entidades da sociedade civil organizada devem ser chamadas a participar. Essa participação visa atender, de forma ampla e irrestrita, através de serviços e programas, os direitos básicos de educação escolar, saúde física e mental, cursos de preparação para o trabalho, atividades de lazer e culturais e tudo mais que os adolescentes têm direito, segundo o ECA. Não se pode esquecer, que a execução das medidas sócio-educativas inscrevem-se no campo da garantia (promoção e defesa) dos direitos da criança e do adolescente, como parte da política de direitos humanos.

Além do investimento em infra-estrutura, é necessário também, investir na capacitação de recursos humanos, formação contínua e sistemática e supervisão de todos os agentes públicos envolvidos no sistema de atendimento direto ao/a adolescente privado [a] de liberdade, para que se possa ter as condições básicas de planejamento e execução de projetos sócio-pedagógicos. Estes projetos devem garantir o protagonismo dos adolescentes infratores, incentivando com que os mesmos participem de atividades de formação pessoal e de desenvolvimento da cidadania. (CONANDA, 2007).

Em relação à institucionalização do [a] adolescente infrator [a], segundo pesquisa feita pelo Fórum Nacional de Dirigentes Governamentais de Entidades Executoras da Política de Promoção e Defesa dos Direitos da Criança e do Adolescente (Fonacriad), em um 
número significativo de estados brasileiros, a maioria dos equipamentos e espaços físicos das unidades de atendimento são inadequados, tanto do ponto de vista pedagógico, quanto da segurança, ocorrendo, inclusive, uma superlotação dos estabelecimentos especializados. Dessa forma, o espaço arquitetônico das unidades de intervenção não está refletindo o programa de atendimento integral ao adolescente em regime sócio-educativo, ao não levar em conta as necessidades pedagógicas que salvaguardam os direitos fundamentais do adolescente. (Ministério da Justiça, 1998)

$\mathrm{O}$ artigo 98 do ECA, sanciona que sempre que os direitos das crianças e adolescentes reconhecidos pela Lei forem ameaçados ou violados por ação ou omissão da sociedade ou do Estado, por falta, omissão ou abuso dos pais ou responsável, e em razão de sua conduta, seguindo esse mesmo patamar as medidas de proteção aplicáveis (art. 101 do Eca):

I - encaminhamento aos pais ou responsável, mediante termo de responsabilidade;

II - orientação, apoio e acompanhamento temporários;

III - matrícula e freqüência obrigatórias em estabelecimento oficial de ensino fundamental;

IV - inclusão em programa comunitário ou oficial de auxílio à família, à criança e ao adolescente; ambulatorial;

V - requisição de tratamento médico, psicológico ou psiquiátrico, em regime hospitalar ou toxicômanos;

VI - inclusão em programa oficial ou comunitário de auxílio, orientação e tratamento a alcoólatras e

VII - abrigo em entidade;

VIII - colocação em família substituta.

Já o artigo 112, expõe as medidas socioeducativas que são aplicáveis somente a adolescentes autorxs de ato infracional o ECA depois de apurada sua responsabilidade após o devido processo legal prevê seis medidas (art. 112):

I. advertência;

II. obrigação de reparar o dano;

III.prestação de serviços à comunidade;

IV. Inserção em regime de semi-liberdade; 


\section{V. internação em estabelecimento educacional;}

De acordo com Sylvia Helena Terra ${ }^{38}$, o Estatuto prevê e sanciona essas medidas sócio-educativas e medidas de proteção eficazes, e reconhece a possibilidade de privação provisória de liberdade ao infrator(a), inclusive ao não sentenciado(a) em caráter cautelar em parâmetros semelhantes aos do Código de Processo Penal que destina aos imputáveis na prisão preventiva - e oferece uma gama larga de alternativas de responsabilização, cuja mais grave impõe o internamento sem atividades externas.

\footnotetext{
"O estudo da história da atenção aos direitos da criança e do adolescente nos permite observar uma mudança paradigmática no campo doutrinário e legal caracterizada pela transição de uma doutrina da situação irregular de caráter funcionalista e criminalizar da pobreza para uma doutrina da proteção integral, fundada na garantia de direitos individuais, difusos e coletivos, incluindo crianças e adolescentes como atores sociais diferenciados, credores de direitos especiais por sua condição peculiar de pessoa em desenvolvimento." (VOLPI, 2001).
}

Pode-se ainda perceber que a vivência nas instituições "ressocializadas", configurase como uma etapa de aprendizado do crime, e jamais como uma etapa de ressocialização. O sentimento de impotência vivida pelos profissionais destas instituições, a histórica precariedade de recursos humanos e materiais e a prática institucional impregnada pelo desrespeito, também comprovam a insanidade do sistema e das políticas públicas. Por seu lado, a sociedade continua solicitando medidas de repressão e se omitindo na luta pela melhoria da qualidade do atendimento público oferecido a estes jovens.

A maior prova da ineficiência do sistema é o destino dos jovens ao sair da instituição. São postos na rua da mesma maneira que entraram, desamparados, sem documentos, sem escolaridade e sem chances de se profissionalização. São jovens estigmatizados. Aqueles que possuem familiares que podem dar suporte emocional e financeiro têm mais chance, se comparados aos que provêm de famílias com menos condições para tal. O meio comunitário, com muita freqüência, contribui reforçando a

\footnotetext{
${ }^{38}$ Assessora jurídica do Conselho Federal de Serviço Social - CFESS
} 
utilização de drogas e o convívio com traficantes. O círculo vicioso se fecha para alguns jovens, contribuindo para a reincidência no ato infracional. (PIERUCCI, 2006).

\subsection{Medidas Socioeducativas de Internação no Brasil}

Existem atualmente no Brasil três tipos de medidas a serem aplicadas à adolescentes em conflito com a lei: a internação convencional, a semiliberdade (quando o infrator(a) pode sair para estudar ou trabalhar) e a liberdade assistida, que envolve a prestação de serviços à sociedade e o comparecimento periódico à Justiça (VOLPI, 2001).

O Estudo de 2003 "Adolescentes em Conflito com a lei. Situação de atendimento institucional no Brasil", do Instituto de Pesquisas Econômicas Aplicadas (IPEA) aponta que uma das grandes fragilidades do sistema socioeducativo brasileiro é a pouca abrangência ou mesmo inexistência das medidas socioeducativas em meio aberto e a incipiente prática de descentralização nos municípios. No Rio de Janeiro, por exemplo, todas as medidas de internação são cumpridas na região metropolitana. Soma-se a isso a precária oferta de Prestação de Serviços à Comunidade e Liberdade Assistida nos municípios do estado. Esta situação faz com que o direito do adolescente ao cumprimento de uma medida socioeducativa equivalente ao ato infracional cometido esteja em risco. Ocorre que, um adolescente que comete um ato infracional pouco grave acaba por não cumprir medidas devido à não oferta das medidas em meio aberto adequadas à situação delituosa leve ou é enviado a cumprir medida em regime fechado, absolutamente incompatível com sua conduta.

Além da pouca abrangência do sistema socioeducativo brasileiro, a maioria das unidades de internação ainda funciona conforme o modelo ultrapassado que se fundamenta no Código de Menores estabelecido pela antiga FUNABEM. Tal modelo se apresenta tanto em relação à estrutura arquitetônica, quanto na sua dinâmica de atendimento e nas

concepções que ainda permeiam as práticas de agentes/educadores, equipes técnicas e direções de unidades. Concepções e práticas exclusivamente punitivas ainda imperam em inúmeras unidades. Segundo o estudo do IPEA acima mencionado, na medida em que as unidades que ainda funcionam no modelo de reclusão "menorista" deixam de estabelecer parcerias com a rede pública e ofertas privadas de serviços, de encaminhar os adolescentes 
para atendimentos e atividades fora das unidades, os custos de manutenção destas unidades tornam-se extremamente elevados em relação aos benefícios produzidos.

Durante o ano de 2002/2003 o CONANDA ${ }^{39}$ e a Secretaria Especial dos Direitos Humanos (SEDH), em parceria com a Associação Brasileira de Magistrados e Promotores da Infância e Juventude (ABMP) e o Fórum Nacional de Organizações Governamentais de Atendimento à Criança e ao Adolescente (FONACRIAD), realizaram encontros estaduais, cinco encontros regionais ${ }^{40}$ e um encontro nacional com juízes, promotores de justiça, conselheiros de direitos, técnicos e gestores de entidades e/ou programas de atendimento socioeducativo. O escopo foi debater e avaliar com os operadores do Sistema de Gestão Democrática (SDG) a proposta de lei de execução de medidas socioeducativas da ABMP bem como a prática pedagógica desenvolvida nas Unidades socioeducativas, com vistas a subsidiar o CONANDA na elaboração de parâmetros e diretrizes para a execução das medidas socioeducativas. Como resultado desses encontros, acordou-se que seriam constituídos dois grupos de trabalho com tarefas específicas embora complementares, a saber: a elaboração de um projeto de lei de execução de medidas socioeducativas e a elaboração de um documento teórico-operacional para execução dessas medidas. ${ }^{41}$

Em fevereiro de 2004 a SEDH, por meio da Subsecretaria Especial de Promoção dos Direitos da Criança e do Adolescente (SPDCA), em conjunto com o CONANDA e com o apoio do Fundo das Nações Unidas para a Infância (UNICEF), sistematizaram e organizaram a proposta do Sistema Nacional de Atendimento Socioeducativo (SINASE). Em novembro do mesmo ano promoveram um amplo diálogo nacional com aproximadamente 160 atores do SGD, que durante três dias discutiram, aprofundaram e contribuíram de forma imperativa na construção deste documento (SINASE), que se constituirá em um guia na implementação das medidas socioeducativas. Depois da construção coletiva de 5 anos aprovado-se o SINASE, no fim do ano de 2006 pelo CONANDA, equivale a uma espécie de lei de execução penal para adolescentes infratores[as] com leis de regulamentação e do funcionamento de todo o

\footnotetext{
${ }^{39}$ O CONANDA, foi criado por Lei Federal n. ${ }^{\circ} 8.242$, de 12 de outubro de 1991.

${ }^{40}$ Na Região Centro-Oeste, realizado nos dias 27 a 29/05/2002 na cidade de Goiânia/GO; na Região Nordeste, nos dias 27 a 29/08/2002 na cidade de João Pessoa/PB; na Região Norte, nos dias 03 a 05/09/2002 na cidade de Belém/PA; na Região Sudeste, nos dias 03 a 05/09/2002 na cidade de Belo Horizonte/MG e na Região Sul , realizado nos dias 09 a 11/10/2002 na cidade de Porto Alegre/RS. Esses encontros foram precedidos, em geral, de momentos estaduais.

${ }^{41} \mathrm{O}$ primeiro documento norteador dos debates no Brasil foi elaborado por Maria Stela Graciane (conselheira do Conanda, representando na gestão, à época, pela PUC/SP).
} 
Sistema Socioeducativo do País. Entre as recomendações, estão a limitação do número de adolescentes por unidade de regime fechado em 90 internos e a oferta de espaços para a prática de atividades físicas e de atividades de profissionalização nesses lugares e o respeito as especificidades de gênero, idade e ato infracional.

A implementação do SINASE objetiva primordialmente o desenvolvimento de uma ação socioeducativa sustentada nos princípios dos direitos humanos. Persegue, ainda, a idéia dos alinhamentos conceitual, estratégico e operacional, estruturado, principalmente, em bases éticas e pedagógicas. $\mathrm{O}$ documento está organizado em nove capítulos. O primeiro capítulo, marco situacional, corresponde a uma breve análise das realidades sobre a adolescência, com foco no adolescente em conflito com a lei, e das medidas socioeducativas no Brasil, com ênfase para as privativas de liberdade. Para tanto, ancorou-se em dados oficiais publicados em estudos e pesquisas. O segundo capítulo trata do conceito e integração das políticas públicas. O terceiro trata dos princípios e marco legal do SINASE. O quarto contempla a organização do Sistema. O quinto capítulo trata da gestão dos programas. O sexto apresenta os parâmetros da gestão pedagógica no atendimento socioeducativo. O sétimo trata dos parâmetros arquitetônicos para os programas socioeducativos; o oitavo, da gestão do sistema e financiamento, e o último, do monitoramento e avaliação. O oitavo e o nono capitulo recomenda-se a limitação do número de adolescentes por unidade de regime fechado em 90 internos e a oferta de espaços para a prática de atividades físicas e de atividades de profissionalização nesses lugares e o respeito as especificidades de gênero, idade e ato infracional. $\mathrm{O}$ anexo apresenta o detalhamento técnico das normas, definições e etapas para elaboração de projetos arquitetônicos e complementares das Unidades de atendimento socioeducativo de internação e internação provisória.

Presidente do FONACRIAD e do Instituto de Atendimento Socioeducativo do Espírito Santo, Silvana Gallina afirmou que é possível notar avanços trazidos pelo SINASE como o aumento de recursos dos estados para a adequação das unidades de internação. Ela, no entanto, alegou que o processo é mais complexo. "Além de maior aporte de recursos públicos, é necessária uma mobilização política forte”, avaliou Gallina.

No Distrito Federal, existem atualmente 2.165 adolescentes cumprindo medidas socioeducativas. Segundo o Secretário de Justiça e Cidadania do GDF, Raimundo Ribeiro, o 
principal desafio é garantir educação formal e preparação profissional dentro dos estabelecimentos de internação. (Secretaria Especial dos Direitos Humanos - SEDH, 2008)

\subsection{Medida Socioeducativa de Internação no Distrito Federal}

Especificamente em relação às unidades de internação para adolescentes em conflito com a lei, forçoso é reconhecer sua inadequação em relação aos parâmetros do Estatuto da Criança e do Adolescente, servindo, a grande maioria delas, apenas como contenção e encarceramento para os(as) adolescentes - fato este que tem sido apontado por muitos como se constituindo em efetiva redução da idade penal no Brasil, uma vez que, a partir dos 12 anos de idade, os adolescentes estariam sendo, na realidade, processados, cumprindo medidas de privação de liberdade, em estabelecimentos sócio-educativos.

Numa breve configuração do sistema de atendimento aos adolescentes que cometeram ato infracional e estão privados de liberdade, observamos que a situação é grave, e vem se arrastando sem solução há mais de uma década. A população na faixa etária de 12 a 18 anos representa $13,6 \%$ do total da população do DF. De acordo com pesquisa realizada por FUCKS (2004) ${ }^{42}$, são 1.423 adolescentes autores de ato infracional, ou suspeitos de terem cometido ato infracional. Esse número representa $0,06 \%$ da população do DF e $0,5 \%$ do total do número de adolescentes nesta faixa etária. Trata-se, portanto, de um universo de adolescentes que o GDF teria total condições de atender dignamente. Atualmente, estão cumprindo medida de privação de liberdade no Centro de Atendimento Juvenil Especializado - CAJE 345 adolescentes $^{43}$, sendo que a capacidade do local é para atender no máximo 190.

Dentre as conclusões da pesquisa realizada por Andréa Fucks (2004) sobre o atendimento aos adolescentes em medida de semi-liberdade, que são ao todo 90, destaca-se: “A mudança paradigmática proposta pelo Estatuto da Criança e do Adolescente não aconteceu no âmbito das práticas sociais, que ainda estão fundamentadas, em muito, na doutrina da situação irregular. A falta de vontade política do Executivo, a morosidade no encaminhamento das ações para a realização do atendimento, os investimentos e ações sem planejamento ou planejados de forma desordenada, a insuficiência e ineficiência na prestação e oferecimento dos serviços (...), a inadequação e insuficiência dos equipamentos

\footnotetext{
${ }^{43}$ Informação do dia 09/09/2005, do CAJE para a Secretaria Especial de Direitos Humanos.
} 
disponíveis para a realização do atendimento compromete a qualidade da prestação dos serviços e denota que o adolescente autor de ato infracional não é prioridade para o governo do Distrito Federal". 44

Recentemente, o Conselho de Defesa dos Direitos da Pessoa Humana (CDDPH), do Ministério da Justiça, aprovou resolução pedindo intervenção federal no sistema de atendimento ao adolescente autor de ato infracional do Distrito Federal, por fortes violações aos direitos humanos, como torturas, negligência, ocorrência de óbitos, instalações subhumana, acesso precário à escola, dentre outras. Desde 1997, 17 adolescentes foram assassinados no CAJE, sob a guarda do Estado, sendo que só em 2004 foram 04 mortes ${ }^{45}$. Em 2005 ocorreram duas mortes: uma no CAJE e um suicídio de um adolescente durante a internação provisória no Centro Soocioeducativo Amigoniano (CESAMI) - centro dirigido pela congregação religiosa dos Amigonianos. Outro aspecto que piora a situação dos jovens presos é o atendimento ser realizado pela Polícia Civil, e não por agentes sociais treinados para tal tarefa. A proposta do governo é simplesmente a de contenção, e não de reeducação social, pois qual é a qualificação da polícia civil para trabalhar os aspectos pedagógicos das medidas sócio-educativas? Outra tendência do GDF tem sido a de terceirizar o atendimento a esses/essas adolescentes, colocando nas mãos da sociedade civil ou congregações religiosas a execução de uma medida que é de responsabilidade legal do Estado.

Esta pesquisa tem como campo empírico a medida de internação executada no Distrito Federal, sentenciada para adolescentes infratoras do sexo feminino, no caso o CAJE; visto que as outras unidades seja de internação provisória ou de semiliberdade não são instituições mistas, ou seja não abarcam adolescentes do sexo feminino; o que já revela uma opressão de gênero que será melhor problematizada no item 4.1 Analise de Dados.

Sendo assim o presente trabalho se propõe a investigar como se encontram as adolescentes privadas de liberdade no CAJE, considerando as suas histórias socioeconômicas, o acesso aos seus direitos e o comprometimento do Distrito Federal para a garantia desses direitos, e ainda, a potencialidade de atendimento a essa faixa etária no citado ente da República Federativa do Brasil.

\footnotetext{
${ }^{44}$ FUCKS, Andréa M. S. L. Entre o Direito Legal e o Direito Real: o desafio à efetivação da cidadania do adolescente autor de ato infracional, Brasília, Dissertação de Mestrado/UnB, julho de 2004, p.193.

${ }^{45}$ Relatório da Comissão Especial do Conselho de Defesa dos Direitos da Pessoa Humana, elaborado a partir de visita feita ao CAJE no dia 03/12/2004.
} 


\subsection{Unidade de Internação no Distrito Federal - CAJE - Centro de Atendimento Juvenil Especializado}

A medida de internação é aquela que coloca $\mathrm{x}$ infratxr sob custódia do Estado, privando-x de liberdade total ou parcial. Esta medida somente pode ser aplicada pelo juiz em caso de infração cometida por meio de grave ameaça ou violência à pessoa e no caso de reincidência de ato infracional grave. Não há previsão de tempo para a internação, contudo, a permanência do jovem nesse estabelecimento não pode ultrapassar o prazo de três anos, devendo ser a mesma avaliada a cada semestre. A libertação será compulsória aos vinte e um anos de idade.

Constata-se, às portas do século XXI, a perpetuação do descaso para com os (as) jovens infratores (as). O governo estadual continua sem encarar como prioridade o atendimento aos jovens nas instituições de cumprimento de medidas socioeducativas e a que apresenta o descaso são as Unidades de Internação. Os Centros de Internação do Brasil demoraram muitos anos para começar a funcionar; algumas instituições ainda se apresentam deterioradas quanto à estrutura física e escassez de material; não se implementou a escola formal nem iniciação profissional efetiva; houve inúmeras trocas de chefia e juízes foram afastados. Continuam, pois, superlotadas, inapropriadas para a socialização dos jovens, desumanas e descumprindo o ECA.

O regime de internação é a medida socioeducativa mais cara dentre o rol das medidas estabelecidas pelo Estatuto. No entanto, pouco se investe nas medidas em meio aberto que são as de menor custo e mais eficazes na contenção das condutas delituosas na medida em que são capazes de alcançar o adolescente quando ele comete um ato infracional de pouca gravidade, atuando para que os atos não tornem a ocorrer nem que aumente sua gravidade. Desta forma, investir maciçamente nas medidas em meio aberto representa a forma mais eficaz de conter o aumento da criminalidade, dando aos adolescentes respostas adequadas a atos infracionais menos graves (cerca de $90 \%$ de todos os atos infracionais imputados a adolescentes no Brasil são considerados pouco graves, ou seja, são delitos contra o patrimônio sem ofensa à pessoa). (BRENNER e MONTEIRO, 2007).

No âmbito do Distrito Federal, com base na Lei no 663 de 1994, criou-se a estrutura do CAJE, a partir disso surgiu a necessidades de novas providencias no que se referiu ao 
detalhamento da proposta para orçar pessoal e efetivar o plano administrativo e as metodologias de intervenção. O CAJE no período de desenvolvimento da pesquisa "CAJE HOJE" estava vinculada à SEAS e, através de convênio, era administrada por servidores da Secretaria de Estado e Segurança Pública que também tem a função de manter a disciplina na unidade. Contudo, a conjuntura administrativa do CAJE mudou com a posse do novo governo do Distrito Federal (Governo Arruda) no início de 2007, e está vinculado ao Ministério da Justiça junto a Sub-Secretaria da Criança e do Adolescentes e de Direitos Humanos do Distrito Federal na seção de Medidas Sócio-Educativas do Distrito Federal, ligadas a Secretaria Especial de Direitos Humanos da Presidência da República.

Um bom prospecto da situação atual do CAJE, pode ser apreendido do relatório realizado pela Comissão Especial da Secretaria Especial de Direitos Humanos (Dez. de 2006). Contatou que há um déficit de 134 servidores na instituição, que deveria contar com 596 servidores. Trabalhavam no CAJE, durante a pesquisa, 253 servidores públicos, 143 terceirizados, 18 agentes de polícia civil; 29 professores e auxiliares da Secretaria de Educação; 7 médicos e auxiliares da Secretaria de Saúde e 11 funcionários para a limpeza. O CAJE tem a capacidade de atender 212 adolescentes e, no período da pesquisa de 2005, estavam internados 330 jovens, verificando-se aí a superlotação e a total desconformidade com as resoluções do CONANDA (Resolução ${ }^{\circ} 46$ de 1996), que só permite o atendimento de quarenta adolescentes por unidade de internação.

A unidade possui dez módulos e distribui xs adolescentes em conformidade com os seguintes critérios: 16 a 18 anos; 18 a 21 anos incompletos; 14 a 16 anos; 12 a 14 anos e ala feminina. Também são separados os adolescentes que são jurados de morte, envolvidos com gangues rivais, infrações sexuais, brigas internas e motivos diversos.

A amostra das unidades de internação de adolescentes em conflito com a lei (2006) relata que a unidade tem quadra esportiva, campo de futebol e piscina; no entanto a utilização da quadra é do campo é feita só pelos adolescentes do sexo masculino. Todos os alojamentos estão em estado precário ou são inadequados e todos se assemelham a celas. Os espaços são pequenos, insalubres, com pouca ventilação, sem higienização, pouca iluminação e com fiação exposta. Devido a este ambiente de insalubridade em que vivem os adolescentes internos do CAJE, foram constatados, tanto no relatório de 2004 quanto no de 2006, diversos problemas de saúde relacionados a dermatoses. Foi verificado também que dentro da unidade 
de internação são receitados medicamentos calmantes para os adolescentes, quando estes estão "nervosos".

Os adolescentes internos freqüentam as aulas e as oficinas profissionalizantes. No entanto, verificou-se no relatório de 2004 que as aulas têm uma hora e meia de duração para cada turma de adolescentes, não há aulas todos os dias úteis e quase meia hora do período de aula é destinado a revista pessoal antes de retornarem às celas. Ainda sobre a escola, o relatório de 2006 mostra que quando os adolescentes estão de castigo, podem ficar ate vinte dias sem freqüentar as salas de aula, as oficinas profissionalizantes, bem como qualquer outra atividade pedagógica. O não-acesso à educação é utilizado como punição, o que demonstra descumprimento ao ECA.

De acordo a dissertação de mestrado realizada por Viviane $\operatorname{Araujo}^{46}(2006)$, pode-se constatar que a sociedade ainda não consolidou uma rede de atendimentos básicos, capaz de sobreviver às mudanças que se processam no plano político-administrativo, de modo a viabilizar uma retaguarda socioeducativa, primeiro passo a ser dado para a implantação efetiva do Estatuto da Criança e do Adolescente.

É importante salientar que xs adolescentes relataram maus tratos no ano de 2005 e 2006, mas somente dois casos foram registradas pela direção. Do final do ano de 2003 até outubro de 2005, aconteceram oito homicídios no CAJE, promovidos pelos próprixs adolescentes. E mesmo depois de importantes ${ }^{47}$ estudos, documentos, relatórios, noticias dos meios de comunicação em massa sobre a implementação de medidas/políticas publicas de curto, médio e longo prazo visando solucionar os problemas do CAJE, e as situações de descaso e vulnerabilidade na qual o mesmo está submerso; não foi suficiente para evitar mortes como a de André Luiz Alcântara de Souza, 16 anos, enforcado na noite de terça-feira (02/09/08) em uma das celas, e culminou para a maior rebelião da historia do CAJE. O secretário de Justiça, Peniel Pacheco, comenta que a principal medida do GDF para solucionar os problemas do CAJE, é a abertura do Centro de Integração de Adolescentes de

\footnotetext{
${ }^{46} \mathrm{O}$ trabalho chama-se: “CAJE - Retratos de um cotidiano de conflitos.

47 "Perfil dos Adolescentes que Morreram Cumprimento de Medidas SocioEducativas no DF, Brasília: Escola Superior do Ministério Publico/Comissão Nacional de Direitos Humanos da Câmara Legislativa do DF/VIOLES-SER-UnB (2006); O relatório sobre a situação do CAJE realizado pela Comissão Especial da Secretaria Especial de Direitos Humanos; Amostra das unidades de internação de adolescentes em conflito com a lei promovido pela Ordem dos Advogados do Brasil - OAB Nacional e pelo Conselho Federal de Psicologia - CFP; Correio Braziliense; Jornal do Brasil, e ainda as Dissertações de Mestrado da Universidade de Brasília dentre outras Universaidades do país, como por exemplo: Araujo (2006), Fucks (2004).
} 
Planaltina (CIAP), que deverá abrigar até 80 internos. A unidade deveria ter ficado pronta em outubro de 2006. Sua inauguração foi marcada para julho do ano passado e depois remarcada para novembro, e aconteceu, já esta funcionando porém ainda com o número baixo de internos.

A Secretaria de Justiça, Direitos Humanos e Cidadania está elaborando um planejamento que vai nortear a política do GDF para o sistema socioeducativo. Além do CAJE, atualmente o sistema conta com o Centro Socioeducativo Amigonianos (CESAMI) e o Centro de Integração do Adolescente Granja das Oliveiras (CIAGO). O CESAMI tem apenas 120 vagas e só recebe menores à espera de julgamento, que podem ficar 45 dias internados. Para o CIAGO, vão adolescentes sentenciados. No CAJE, também deveriam ficar apenas sentenciados, mas a unidade tem uma ala para adolescentes que aguardam decisão judicial. O CAJE tem cerca de 300 adolescentes cumprindo pena de restrição de liberdade e 70 internos provisórios, que ainda aguardam decisão da Justiça. (Correio Braziliense, Novembro 2008).

Coordenadora do Fórum de Defesa dos Direitos das Crianças e Adolescentes do DF, Perla Ribeiro acrescenta aos problemas do sistema na capital federal a falta de estrutura das unidades. "Os servidores não têm nem mesmo computador para fazer um relatório", disse. Ela acredita que a direção do CAJE tem boa vontade, mas não conta com apoio do governo local. "O orçamento é quase zero", reclamou. O MPDFT divulgou um levantamento da aplicação de recursos pelo GDF no CAJE. A equipe do de Andrade constatou que, neste ano, o governo gastou cerca de R \$ 6 mil por mês na unidade. Segundo o promotor, esse valor é muito baixo para gerir uma instituição com quase 300 internos e 450 servidores. (Correio Braziliense, Novembro 2008).

\subsection{Adolescente Infratora}

Há uma diferença quantitativa grande entre os gêneros no universo das transgressões, na esfera infracional gira em torno de uma (1) jovem para cada grupo de dez (10) rapazes. A questão da divisão social de gênero que se faz presente no mundo infracional é fruto da estratificação que também é o principal pilar de sustentação. A estrutura fascista é inerente a qualquer regime de força, o crime é egoísta e individualista, afinal "Robin Wood" só existe 
na literatura, sendo que essas adolescentes os códigos e significados são tratadas de forma subalterna pensadas sempre a partir de padrões patriarcais de domínio (ESPINOZA, 2004).

A explicação biológica para a condição naturalmente subalterna da mulher sustenta-se até o avançar do capitalismo industrial. Neste momento, as condições históricas se transformam. O movimento feminista, organizado coletivamente, surge com o objetivo de opor-se a situação subordinada das mulheres "pegando carona" nas mudanças que marcaram a história ocidental européia a partir do século XVIII, vinculado ao desenvolvimento da democracia através das Revoluções Francesa e Americana. Marco teórico contra a visão essencialista imposta pelas diferenças anatômicas é apresentado pelo filósofo Ponlain de la Barre que, já entre 1673 e 1675, contrapôs os defensores da inferioridade feminina. Seu ideário sintetiza-se na idéia de que as desigualdades entre homens e mulheres não são conseqüência das desigualdades baseadas na biologia, mas sim, resultado das desigualdades sociais e políticas impostas a elas em seu tempo (AZEVEDO e GUERRA, 2005).

COSTA (1989), em "Meninas da Vida", pergunta: "por que apenas um número reduzido de meninas chega a situação extrema?" E acrescenta: "É na condição de adolescente e de mulher degradada pessoal e socialmente, (...), que se radica o ponto a partir do qual se pode iluminar um pouco melhor os mecanismos que fazem com que um número menor de meninas do que de meninos se encontrem inteiramente imerso na vida da rua".

As adolescentes que enveredam na trajetória infracional são vistas, em geral, como uma "ameaça menor à sociedade", porque as suas estratégias de sobrevivência são brandas visto o sistema machista que sempre as coloca em uma situação de vulnerabilidade cercada de espaços de submissão. Normalmente apelam para a mendicância e prostituição, pequenos furtos, etc. Desta forma, "faz com que o alerta e a repressão sejam mais freqüentes e automáticos para os meninos do que para as meninas". Até mesmo por conta do sistema de opressão que o patriarcado instalou, enraizado culturalmente. A reação de uma adolescente mulher como anti-heroina de um sistema vigente exploratório e injusto é em certa medida menos disputada e comum do que por adolescentes homens cujo seu espaço já é naturalizado historicamente a pseudo natureza superior dos homens o que remete à dominação masculina, ao sexismo e às práticas rígidas e intransponíveis entre os gêneros. (WELZER-LANG, 2001) 
Desta forma a natureza sempre foi utilizada como principal (senão única) responsável pelas diversas formas de desigualdade humana, e em particular, neste estudo, as desigualdades entre homens e mulheres. O que nos chama atenção para uma análise mais atenta são quais os caminhos percorridos pela sociedade que nos leva a um ambiente propicio para que homens e mulheres tenham acesso desigual a recursos e bens simbólicos escassos. E ainda, como a constituição do gênero, feminino ou masculino, interfere nessa trajetória (HEILBORN, 2006).

Os espaços na sociedade "marginal" são ainda mais estreitos para elas, em um mundo onde o gênero masculino é exaltado, onde a sagacidade, a força, a individualidade são básicas para a sobrevivência e os "atributos femininos" historicamente construídos de docilidade, fragilidade, paciência, não adiantam de nada; muito pelo contrário, servem ainda mais para a humilhação e exploração. Assim, a estratégia de sobrevivência no mundo violento e cruel das ruas passa necessariamente pela "mimetização" dos atributos masculinos de gênero. E aquelas mais fracas, que não conseguem se impor amargam uma submissão estranhamente cruel: não barram o autoritarismo masculino e o comportamento de "Amélia" não convencem as colegas, "mulheres" iguais a elas.

O processo que leva as adolescentes infratoras à (des)construção da identidade de gênero é o mesmo que exacerba a construção do gênero masculino nos adolescentes, produzindo o "machismo" expressado nas suas músicas, nos relacionamentos afetivos, sociais e sexuais. Uma sociedade onde as diferenças de poderes são enormes, prenha de violências de todas as sortes ou azares, e com poucas opções de expressões culturais, não incentiva a vida cooperativa. A violência reproduz luta de classes e a lógica da dominação nas relações de gênero que deviam estar escamoteadas e ser representadas como tratamento diferenciado para a igualdade de direitos, ou seja diferença não pode ser sinomino de desigualdade (LAVINAS, 1996).

Onze adolescentes infratoras, entre 14 e 17 anos, do Centro Socioeducativo Maryse Mendes, localizado na Zona Centro-Oeste de Manaus, fizeram um motim na instituição, no último dia 19. Elas reivindicavam melhor tratamento. Para tentar chamar a atenção da direção da unidade, as meninas quebraram a porta do alojamento, tumultuando o local. A Polícia Militar foi acionada e elas foram encaminhadas para a Delegacia Especializada em 
Apoio e Proteção à Criança e ao Adolescente. Até a tarde de terça-feira (20), as adolescentes esperavam na delegacia uma decisão do juiz da Infância e da Juventude, Antônio Celso Gióia, para serem levadas ao setor de acautelamento do Centro de Atendimento ao Adolescente Infrator, também na Zona Centro-Oeste, onde ficarão provisoriamente até a decisão judicial. $\left(\mathrm{ANDI}^{48}, 2007\right)$

De acordo com as internas, os motivos que as levaram a iniciar o motim foram superlotação do alojamento e o fato de três garotas terem sido levadas, injustamente, à contenção, isolamento onde ficam as internas que desrespeitam as normas internas. "Elas foram para a contenção sem fazer nada. Por isso, resolvemos quebrar tudo. O quarto que a gente dorme também é muito pequeno para todo mundo", afirmaram as adolescentes. As internas demonstram muita revolta com a situação. De acordo com a secretária estadual de Assistência Social, Maryse Mendes, o Centro Socioeducativo precisa de recursos humanos melhor preparados. "Temos hoje 30 funcionários que trabalham 24 horas com as meninas. Mas eles são muito antigos, não estão tão preparados para lidar com certas situações", relatou. (ANDI, 2007)

Em julho de 2007 no Estado do Pará, uma garota de 15 anos ficou presa numa cela com vinte homens em uma delegacia por mais de um mês. Ao sair da cadeia a jovem procurou o Conselho Tutelar e disse que sofreu abusos sexuais no período em que ficou presa. Além de uma atitude absurda, o chefe da delegacia desrespeitou o ECA que, no artigo 235 , prevê a detenção de seis meses a dois anos para quem mantiver menores ${ }^{49}$ em delegacias por mais de cinco dias e em companhia de adultos. Depois das denúncias desta garota de 15 anos, muitas histórias de garotas que são pressas irregularmente em cadeias comuns para adultos começaram a surgir. (Jornal do Brasil, 2007).

Segundo dados da ANDI, apenas no Estado de São Paulo existem unidades de internação destinadas a garotas, totalizando três (3). No total são 217 meninas internas. Nas unidades onde elas estão raramente há rebeliões ou fugas. Como o espaço é voltado para um publico especifico, do sexo feminino o tratamento diferenciado é garantido, o que pode ser observado na fala a agente que trabalha em uma das unidades citadas acima: “...Alem da

\footnotetext{
${ }^{48}$ Agência de Notícias dos Direitos da Infância, cuja sede fica em Brasília - DF

${ }^{49} \mathrm{O}$ termo menor aqui é utilizado no que se pauta a maioridade no Brasil seguindo como marco referencial a Constituição Federal e o Estatuto da Criança e do Adolescente (art. 228 da CF e art. 104 do ECA).
} 
especificidade de ser um espaço só para mulheres, como acontece em presídios femininos as adolescentes tem que ter esse principio garantido pelo Estado assim como para o publico adulto é uma questão de segurança publica, ainda vejo como um absurdo nos sermos o único Estado que possuem unidades para públicos específicos e as outras serem mistas, aqui nossas internas são em pequeno número fica mais fácil dar um tratamento diferenciado. A maior parte delas estuda faz cursos profissionalizantes, que vão desde bordado e crochê até aulas de artesanato, pintura, teatro, fotografia, música... Assim como os meninos, a maioria das garotas estão internadas por uso e tráfico de drogas. Muitas delas apresentam histórico de abuso sexual, seja por parte de outras meninas dentro das unidades, seja anterior a internação, abusadas por pais, padrastos, tios, irmãos, policiais e outros homens mais velhos..."

As noticias acima, que foram veiculadas em importantes meios de comunicação brasileiros, só demonstra as fragilidades e o tanto que o Sistema Socioeducativo Brasileiro não está preparado para lidar com a diferença de gênero como especificidade e fere um dos principais enfoques: "Respeito à diversidade étnico-racial, gênero e orientação sexual",50 garantido pelo SISTEMA NACIONAL DE ATENDIMENTO SOCIOEDUCATIVO SINASE, que é uma política pública social de implementação do atendimento das medidas socioeducativas previstas no ECA (art. 112 e 55).

A realidade do DF no trato das adolescentes infratoras, também não está em consonância com o Capitulo 6 do SINASE, no que diz respeito à Parâmetros de Gestão Pedagógica no Atendimento Socioeducativo, do eixo 10, "Diversidade étnico-racial, de gênero e de orientação sexual norteadora da prática pedagógica" em que as questões da diversidade cultural, da igualdade étnico-racial, de gênero, de orientação sexual deverão compor os fundamentos teórico-metodológicos do projeto pedagógico dos programas de atendimento socioeducativo; sendo necessário discutir, conceituar e desenvolver metodologias que promovam a inclusão desses temas, interligando-os às ações de promoção de saúde, educação, cultura, profissionalização e cidadania na execução das medidas socioeducativas, possibilitando práticas mais tolerantes e inclusivas.

\footnotetext{
${ }^{50}$ SINASE- Capitulo 6 - "Parâmetros de Gestão Pedagógica no Atendimento Socioeducativo”, eixo 10.
} 
Dezoito anos após a promulgação da lei, muitas críticas têm surgido acerca das medidas legais propostas pelo ECA, e muitos direitos não são garantidos no que tange as relações de gênero nas instituições de cumprimento de Medidas Socioeducativa Brasileira. Outra problemática é sobre a existência de Unidades de Internação e Casas de Semiliberdade voltadas para o sexo feminimo. No Brasil existe somente 3 unidades de internação em um único Estado (São Paulo), para adolescentes infratoras como citado acima, e o caso se agrava quando falamos de Casas de Semi-Liberdade. Não existe no Brasil uma sequer Casa de Semi-Liberdade para adolescentes do sexo feminino, o que vemos são unidades de internação mistas e não se fala nem aborda nada sobre a temática, e pode ser exemplificado na fala de uma adolescente interna do CAJE:

"Se nós somos sentenciadas pra puxar cadeia de SEMI viche é treta somos mandadas direto pra cá nem tem Casa de Semi pra nós mulheres" (Interna do CAJE - "Pesquisa CAJE HOJE"_Junho 2006).

O cumprimento de Medida Socioeducativa de Semiliberdade para adolescentes do sexo feminino, é comprometido quando lhe cerceam o direito do cumprimento da real medida e são realocadas para o cumprimento de uma medida da qual a adolescente não fora sentenciada, por incompetência e fragilidade das instituições publicas que não garantem a aplicabilidade de políticas publicas com o recorte de gênero ${ }^{51}$; fruto da manutenção sistema capitalista que cria mecanismos de opressão como o mito da igualdade social forçosa, e esses mecanismos na própria sociedade que impedem a tomada de consciência: a revolta contra o sistema capitalista vigente completamente opressor, onde as pessoas têm a ilusão de que vivem numa sociedade de mobilidade social:

A estrutura dos elementos econômicos fundamentais da sociedade não é alcançada pelas tempestades que agitam o céu da política." Outra parte da sociedade leva, por seu lado, uma vida econômica inteiramente parasitária. O Estado, o aparelho do poder estatal, não é para elas, como para as classes dominantes na sociedade capitalista, um meio de impor, se necessário pela violência, os princípios de sua dominação econômica ou de procurar pela violência as condições de sua dominação econômica (como o é para a colonização moderna)

\footnotetext{
${ }^{51}$ Políticas públicas com recorte de gênero são políticas públicas que reconhecem a diferença de gênero e, com base nesse reconhecimento, implementam ações diferenciadas para mulheres. Essa categoria inclui, portanto, tanto políticas dirigidas a mulheres - como as ações pioneiras do início dos anos 80 - quanto ações específicas para mulheres em iniciativas voltadas para um público mais abrangente
} 
Não é pois uma mediação da dominação econômica da sociedade, é imediatamente essa própria dominação. Não é o caso somente de quando se trata pura e simplesmente de apossar-se de terras, de escravos, etc., mas também das relações econômicas" ditas pacificas. ( LUCKAS, 1920)

Em janeiro de 2007, Elionilde Costa, ex-coordenadora da Casa de Semiliberdade do Gama conjuntamente com o promotor de Infância e da Juventude do Ministério Público do Distrito Federal e Territórios (MPDFT), Anderson Pereira de Andrade propuseram a criação de uma Casa de Semiliberdade Feminina, o processo já corre há mais de um ano e meio e nada se fala. A coordenadora afirma que o que acontece é um desprestigio, fruto de uma sociedade patriarcal e para além dessa problemática ainda tem o fato de ser um contingente pequeno. “...Totalizam por ano 30 a 40 meninas que são setenciadas para a medida socioeducativa de internação 8 ou 6 são sentenciadas para o cumprimento de medida de semi, e o desprestigio é tamanho que elas são obrigadas a cumprirem internação, descasso pleno e nítido do Estado, e no julgamento acaba não existindo a sentença de semi para as meninas, cadê o tratamento diferenciado o principio da isonomia? A formação cultural de uma menina é totalmente diferente de um menino tem que ser levado em consideração sim e estar em conformidade com o SINASE..."

Sendo assim, as relações de gênero, que refletem as formas de distribuição de direitos e poderes numa determinada estrutura social, encontram nas Medidas Sócio-Educativas ambiente propício para a manutenção das desigualdades e dos machismos de uma sociedade contemporânea. No sistema de execução de Medidas Sócio-Educativas, seja ela qual for, e de qualquer forma aplicada, haverá sempre um caráter retributivo. E esta retributividade se sustentará na autoridade da força, logo as Medidas Sócio-Educativas além de não servirem para modificar as desigualdades nas relações de gênero, também não servem para o que se propõe, o principio de construção de um projeto societário mais justo e democrático efetivamente onde o gênero não pode ser um mediador hierárquico das relações sociais. 


\section{METODOLOGIA}

Com base na metodologia feminista (No tópico 3.1, o método feminista será explicitado de acordo com o material a ser vasculhado), este trabalho consistirá em uma investigação no campo das Ciências Sociais, onde o método escolhido para pesquisa foi o estudo de caso, através da historia de vida de adolescentes internadas no CAJE em 2006 e para além disso ainda foi feito uma analise com base documental de dados secundários da Pesquisa "CAJE HOJE".

Portanto, os procedimentos para a execução da coleta de dados e operacionalização do presente Trabalho de Conclusão de Curso (TCC) seguiram a seguinte ordem cronológica exposta abaixo:

a) Fontes Documentais: arquivos históricos, registros estatísticos, relatórios institucionais, legislações vigentes e documentos de comunicação de massa (internet); que consistiu no levantamento bibliográfico;

b) Analise e coleta dos dados: produzidos pela Pesquisa "CAJE HOJE": dados quanti-qualitativos, que orientaram a analise de dados, para a produção um Estudo de Caso sobre a categoria gênero nas questões concernentes a Medidas Socioeducativa de Internação no Distrito Federal. Os dados coletados totalizaram 33 adolescentes do sexo feminino, e 190 adolescentes do sexo masculino cumprindo medida socioeducativa de internação, para efeitos dessa pesquisa serão aproveitados somente as adolescentes do sexo feminino; cujos instrumentais de Pesquisa seguem nos anexos, lembrando que os mesmos tiveram somente efeito motivadores o que foi observado foi a Historia de Vida dessas adolescentes com a perspectiva de uma travessia coletiva e histórica partilhando (in)certezas que provocou para a construção e consolidação de uma nova cultura no trato das questões relativas a essas adolescentes que cometeram atos infracionais.

c) Estudo de Caso: os dados são coletados sob condições de ambiente não controlado, isto é: em contexto real, cujo a fonte das evidencias é o registro em arquivo das entrevistas, que permitiu construir a Historia de Vida das adolescentes sentenciadas a partir de 2006, da Pesquisa “CAJE HOJE”; através da observação direta e participante; 
d) Elaboracão do Estudo de Caso: A partir da elaboração do Estudo de Caso foi eleito 3 situações emblemáticas que foi dado um tratamento mais detalhado configurando-se em historias de vida que constiuiram-se em dados relevantes para as conclusões deste trabalho, apresentados no item de Analise de Dados, sistematizado pelo uso de evidencias múltiplas/múltiplos métodos tendo como referencial base para a analise o Método Feminista para a Pesquisa Social (REINHARZ, 2008).

\subsection{Método}

\section{METODOLOGIA FEMINISTA}

O método utilizado nesta pesquisa adota o prisma de analise simbólica dentro da tradição feminista; ou seja Método Feminista para a Pesquisa Social (metodologia feminista), e apontará concordâncias com a perspectiva marxista ${ }^{52}$, adotando a posição teórica de problematizar a percepção e valorização do lugar de participação efetiva das mulheres, na garantia de direitos demarcados pelos dois niveis de diferenças que as condições sexuais comportam ao lidar com o gênero na instituição CAJE sem ferir com os princípios garantidos pelo ECA ${ }^{53}$; SINASE; Convenção para a Eliminação de Todas as Formas de Discriminação contra a Mulher; Convenção para Prevenir, Punir e Erradicar a Violência contra a Mulher; Convenção contra a Tortura e Outros Tratamentos ou Penas, Cruéis, Desumanos e Degradantes e Convenção sobre os Direitos da Criança.

A analise feminista foi possibilitada pela historia de vida das adolescentes do CAJE conjuntamente com a analise de dados secundários produzidos pela Pesquisa "CAJE HOJE" que evidenciarão o panorama atual do cumprimento de medida socioeducativa para adolescentes do sexo feminino.

\footnotetext{
52 Quando falamos de perpectiva marxista estamos nos referindo ao método do materialismo histórico e dialético, criado por Karl Marx que considera a dinâmica dos processos históricos determinados pela realidade concreta e construída pelos homens e mulheres nas suas múltiplas relações.

53 Artigo $5^{\circ}$ do Estatuto da Criança e do Adolescente (ECA) é enfático ao explicitar que "nenhuma criança ou adolescente será objeto de qualquer forma de negligência, discriminação, exploração, violência, crueldade e opressão, punido na forma da lei qualquer atentado, por ação ou omissão, aos seus direitos fundamentais". Igualmente, o artigo 15, do mesmo Estatuto (ECA), prevê que "a criança e o adolescente têm direito à liberdade, ao respeito e à dignidade como pessoas humanas em processo de desenvolvimento e como sujeitos de direitos civis, humanos e sociais garantidos na Constituição e nas leis". Da mesma forma, o artigo 17, do ECA, estabelece que "o direito ao respeito consiste na inviolabilidade da integridade física, psíquica e moral da criança e do adolescente, abrangendo a preservação da imagem, da identidade, da autonomia, dos valores, idéias e crenças, dos espaços e objetos pessoais".
} 
Através do estudo de caso foi possível captar o que acontece na intersecção do individual com o social, assim como permite que elementos do presente fundam-se a evocações passadas. QUEIROZ (1988) coloca o estudo de caso no quadro amplo da história oral que também inclui depoimentos, entrevistas, biografias, autobiografias. Considera que toda história de vida encerra um conjunto de depoimentos e, embora tenha sido (a) o pesquisador(a) a escolher o tema, a formular as questões ou a esboçar um roteiro temático, é (a)o narrador(a) que decide o que narrar. A autora vê na história de vida uma ferramenta valiosa exatamente por se colocar justamente no ponto no qual se cruzam vida individual e contexto social.

CAMARGO (1984) complementa que o uso da história de vida possibilita apreender a cultura "do lado de dentro"; constituindo-se em instrumento valioso, uma vez que se coloca justamente no ponto de intersecção das relações entre o que é exterior ao indivíduo e aquilo que ele traz dentro de si. O mesmo pensa BECKER (1994) acrescenta que a história de vida aproxima-se mais do terra a terra, a história valorizada é a história própria da pessoa, nela são os narradores que dão forma e conteúdo às narrativas à medida que interpretam suas próprias experiências e o mundo no qual são elas vividas.

Diz-nos DENZIM (1984) que a temporalidade é básica no estudo das vidas e distingue duas formas de temporalidade. O tempo mundano relacionado ao presente, passado e futuro como horizonte temporal contínuo e o tempo fenomenológico que é o tempo como fluxo contínuo, é o tempo interior, contínuo e circular. Diz ainda que uma vida possa ser mapeada em termos de episódios cruciais de cujo manejo resultam os seus significados. E, contando delas, as pessoas contam mais do que uma vida, elas contam a vida de uma época, de um grupo, de um povo. Isto se conecta aos conceitos apresentados por Shulamit Reinharz, em Feminist Methods in Social Research, para definir o que é pesquisa feminista.

Naomi Black, uma das leituras que embasa Reinharz, a define como aquela pesquisa que "insiste no valor da subjetividade e da experiência pessoal” (BLACK apud REINHARZ, 2008). Betina Lima também alude a importancia da experiência cunhando uma noção que a define como "mais representativa de uma posição do que de uma essência" (LIMA, 2008: 5). É pela aproximação a essas concepções que se delineia a inserção metodológica desta pesquisa. Tal aproximação se define, também, como empreitada de feminizar a produção de conhecimento, a partir de um reconhecimento da "necessidade de reformar as práticas de pesquisa" (REINHARZ, 
2008) para que contemplem uma amplitude maior de perspectivas, maneiras de pensar, ampliando assim o próprio cânone epistemológico.

Este cânone é acusado, entre outras graves falhas, de ser refratário às mulheres e ao dito feminino. Betina Lima expõe a questão explicitando os mecanismos de operação dessa exclusão de mulheres: "A exclusão das mulheres da ciência foi mapeada de duas formas: a horizontal ou territorial, que trata da divisão de áreas do conhecimento caracterizadas em femininas ou masculinas nas ciências, e a vertical ou hierárquica, que se refere à exclusão das mulheres do topo da carreira científica" (LIMA, 2008). Este trabalho se alinha, então, a um fazer cientifico que "passa necessariamente por questionar os pressupostos da ciência conhecidamente androcêntricos da universalidade, neutralidade e objetividade. Valores que, apesar de sua política de não-localização e descomprometimento, incorporam o homem, branco, heterossexual, eurocêntrico, capitalista, patriarcal, falocêntrico como sujeito do conhecimento." (LIMA, 2008)

Produzir teoria feminista é, entre outros desejos e objetivos, borrar as distinções que cristalizam determinadas rupturas, como a relação hierárquica entre sujeito (pesquisador/a) e objeto (pesquisada/o). É por tanto que assumo a narrativa do texto deste trabalho em primeira pessoa, para que fique nítida a implicação que existe entre quem fala e sobre quem se fala. Esta ferramenta é também fundamental à "construção de saberes localizados, ou seja, saberes posicionados, que recusam o descomprometimento do incorpóreo, que assumem sua visão parcial e que permitem, ao tornarem-se parte do que estudam, desenvolverem uma relação interativa entre sujeitos." (REINHARZ, 2008). Tal como proposto pela autora, também abandono, aqui, a "relação binária de apropriação sujeito/objeto" (ibidem, 2008:10) rumo à construção de um texto que tenha espaço para comportar a pessoalidade dos encontros que tive com as e os adolescentes no CAJE sem que esses relatos sejam feitos de maneira impessoal.

Este é um trabalho sobre pessoas escrito por uma pessoa, e tentando conciliar a comunalidade das experiências que tivemos juntas, é que uso da metodologia feminista para fundamentar e orientar o trato com os dados conseguidos ao longo da pesquisa. Para nomear as ferramentas metodológicas utilizadas, alguns recursos fundamentais foram o método da historia de vida, que se junta ao método de estudo de caso e a analise de dados quantitativos, configurando o que Reinharz chama de técnica dos "múltiplos metodos" 


\subsection{Técnicas}

As técnicas utilizadas nessa pesquisa foram a analise de dados secundários da Pesquisa "CAJE HOJE" fonte documental no CEDECA, conjuntamente com a atual coordenadora do Centro, a qual permitiu um Estudo de Caso, através da Historia de Vida das 33 adolescentes entrevistas no período da Pesquisa (2006) que participei na função de estagiaria do CEDECA. Deste universo de 33 adolescentes foram escolhidas 3 adolescentes, que serão chamadas dos seguintes nomes fictícios: Pagu, Anastácia e Bell. Sobre o aspecto ético, de que todas as adolescentes tiveram sua identidade preservada, e no período da entrevista e consentiram a aplicação do instrumento de Pesquisa "CAJE HOJE" 54 (anexo II).

Os dados coletados na Pesquisa "CAJE HOJE", seja com contato direto com esses/essas adolescentes ou com a analise processual dos prontuários/fichas/processos e pareceres sociais dos(as) adolescentes internos(as), foram de fundamental importância para a elaboração deste estudo.

A seleção das entrevistadas foi realizada pela equipe de Pesquisa "CAJE HOJE", depois de pinceladas as categorias analíticas que perpassam por Maus Tratos, Perfil dxs Adolescentes, Rebeliões, Investimento Finanças e Orçamento, Super Lotação, Violência Interna, Irregularidades, Precarização da Política de Assistência, Rebeliões e Homicídios.

Intenta-se a priori, depois de motivada pelas entrevistas Pesquisa "CAJE HOJE", realizar um estudo de caso por meio de recursos técnicos da historia de vida de três adolescentes (Anastácia, Bell e Pagu). A técnica de Historia de Vida corresponde a uma denominação genérica em formação e em investigação, visto que se revela como pertinente para a autocompreensão do que somos, das aprendizagens que construímos ao longo da vida, das nossas experiências e de um processo de conhecimento de si e dos significados que atribuímos aos diferentes fenômenos que mobilizam e tecem a nossa vida individual/coletiva. Tal categoria integra uma diversidade de pesquisas ou de projetos de formação, a partir das vozes dos atores sobre uma vida singular e vidas plurais, no particular e no geral, através da

\footnotetext{
54 A petição da Pesquisa permitiu a coleta de dados em todas as unidades de internação para adolescentes privados(as) de liberdade que compreendem CAJE, CIAGO e CESAMI. A coleta deu-se no CAJE e CIAGO por conta dos prazos judiciais, e o universo considerado no presente TCC ficara restrito ao CAJE, visto que no CESAMI não existem adolescentes do sexo feminino. No CAJE, a coleta de dados se deu por parte de toda a equipe responsável pela pesquisa, que trouxe saldos positivos: conseguimos analisar 194 fichas dos(as) internos(as) e entrevistrar 30\% do universo total, que é o mínimo soliticidado pelas normas do Cnpq para validar a pesquisa, desse total só serão consideradas as adolescentes do sexo feminino que contabiliza 33.
} 
tomada da palavra como estatuto da singularidade, da subjetividade e dos contextos dos sujeitos.

Classificada como método, como técnica e ora como método e técnica, a abordagem biográfica, também denominada de história de vida, apresenta diferentes variações face ao contexto e campo de utilização. Evidencio, com base em QUEIROZ (1988), que a abordagem biográfica tanto é método, porque logrou no seu processo histórico vasta fundamentação teórica, quanto é técnica, porque também gozou de conflitos, consensos e implicações teórico-metodológicas sobre a sua utilização. As variadas tipificações ou classificações no uso do método biográfico inscrevem-se no âmbito de pesquisas sócioeducacionais como uma possibilidade de, a partir da voz dos atores sociais, recuperar a singularidade das histórias narradas por sujeitos históricos, sócio culturalmente situados, garantindo o seu papel de construtores da história individual/coletiva intermediada por suas vozes.

\section{APRESENTAÇÃO E ANALISE DO OBJETO DE ESTUDO}

O CAJE - Centro de Atendimento Juvenil Especializado (2006/2008) comporta adolescentes do sexo masculino e feminino de 13 a 20 anos (alguns/algumas têm mais de 18 anos por haverem entrado no CAJE pouco antes de atingirem a maioridade), que cometeram atos infracionais, o tempo de internação varia de acordo com sua situação infracional. Em geral, a medida socioeducativa dura três meses, mas pode ser agravada de acordo com a natureza do ato, passagens passadas ou o histórico de violência dx jovem, podem ficar internadxs no máximo três anos, o vulgo "puxar cadeia". Sua localização é na 916 Norte Brasília - Distrito Federal. Segundo o Ministério Público do Distrito Federal e Territórios (MPDFT) investe mensalmente no Caje: R\$ 6 mil. A capacidade máxima de internxs é de 240, a lotação de setembro de 2008 marca 270 adolescentes. (Ministério da Justiça, 2008)

No caso especifico das adolescentes nota-se que os atos infracionais mais praticados são os de furto, roubo, homicídio, ameaça de morte e trafico de drogas, após julgadas pela Vara da Infância e da Juventude, independente de sentenciadas para cumprimento das medidas socioeducativas seja de Semiliberdade ou Internação elas são sentenciadas para cumprir medida no CAJE. Há uma ala para as internas, cuja ventilação é precária e o espaço bem menor quando comparado com o dos adolescentes do sexo masculino. 
A trajetória infracional das adolescentes no CAJE, em sua maioria acontece por conta de um namorado/companheiro/e ou marido, seja para acompanhar-lo nas chamadas "gangues" ou até mesmo por rivalidades entre amigas que disputam o mesmo macho. Todas as adolescentes entrevistadas tem o histórico de terem sido abusadas e ou violentadas sexualmente.

Essas duas ponderações cristalizam a relação de submissão e subserviência, fruto de uma sociedade patriarcal como já exposto acima. A historia não só dessas garotas mas das mulheres brasileiras como um todo, pensadas através de padrões masculinos a partir do macho para o macho e viver em função dele, não recria espaços de defesa de direitos e luta por melhores condições dentro do CAJE e em uma dimensão mais sócio-cultural, pelo contrario enfraquece a luta dessas adolescentes por políticas públicas que contemplem suas especificidades de gênero. As formas de rivalidade entre as garotas fazem parte do cotidiano da Unidade de Internação e refletem em formas de rivalidade variadas nas relações afetivas, competição no trabalho, na criatividade e até paradoxalmente, numa admiração sem limites e por isso redutora de si, de uma líder, Enquanto a mulher olhar para outra mulher como rival, não pode haver a defesa de uma verdadeira causa comum; e muito menos uma defesa da Mulher.

Outro traço marcante registrado nas historias de vida das adolescentes para efeitos de apresentação do objeto de estudo, é o recorte racial, todas as adolescentes eram pardas de baixa renda (pobres). Mas é importante ressaltar aqui que, a despeito de como entendamos os diversos traços que nos formam, existe efetivamente no CAJE algum tipo de opressão que tenta desvalorizá-las, como é o caso do racismo, do sexismo e do classismo, por exemplo, que tentam fazer com que diferenças de raça, sexo/gênero e classe sejam hierarquizantes no processo de mobilidade social brasileira.

\subsection{ELAS X ELES: O Capital institucionalizado no CAJE - "Discurso da igualdade de gênero forja desigualdades insuperáveis e a critica ao enquadramento para abafar as diferenças de gênero"}

Segundo Volpi (2000), no que se refere às medidas aplicáveis àquelxs que têm seus direitos violados e ameaçados ou ainda àqueles que ameaçam ou violem direitos de outrem, a resposta social determinada pelo novo paradigma legal não rompe no seu sentido mais 
profundo, com uma perspectiva funcionalista. Tanto os programas de proteção aplicados aos/à negligenciadxs, maltratadxs, abusadxs, desrespeitadxs e que têm seus direitos negados quanto as medidas sócio-educativas aplicadas aos descumpridores(as) da lei, constituem-se em alternativas de socialização tradicional, cujas obrigações reduzem-se à integração familiar, à colocação profissional, à freqüência à escola e ao desenvolvimento de atividades esportivas e culturais.

No contexto das adolescentes infratoras do DF, as abordagens universalistas e a não constituição de uma abordagem especifica acaba não desnaturalizando hierarquias de poder baseadas em diferenças de sexo, que tem sido um dos eixos centrais dos estudos de gênero. Estabelecer a distinção entre os componentes - natural/biológico em relação a sexo e social/cultural em relação a gênero - foi, e continua sendo, um recurso utilizado pelos estudos de gênero para destacar essencialismos de toda ordem que há séculos sustentam argumentos biologizantes para desqualificar as mulheres, corporal, intelectual e moralmente; o simples fato da efetivação do processo de socialização não reconhecer que o tratamento para uma adolescente do sexo feminino é completamente diferente de uma adolescente do sexo masculino já constitui uma violência de gênero. A violência exercida sobre o sexo feminino é conforme PERRUCI (1997):

"[...] produto, antes de tudo, da dominação que sobre ela exerce o homem. Existe, em maior ou menor escala, em todas as partes do mundo, mesmo nos países onde se prega uma filosofia social de absoluta igualdade sexual na repartição das tarefas sociais" (apud SANTOS, 1997, p.09). Santos acrescenta que: "[...] em países onde a ideologia machista impera como no Brasil, a desigualdade na valorização dos sexos coloca a mulher como um ser em geral subalterno, desprestigiado, submisso, passivo, na maioria de suas relações e no modo como são (ou não) respeitadas" (PERRUCI, 1997, p.55).

As categorias usualmente adotadas enquanto estratégias são, na maioria das vezes, explicitadas por expressões com o prefixo "re" como que para firmar a idéia de retorno a uma situação anterior de normalidade. Recolocação familiar, reestruturação da família, reeducação, re-socialização, recomposição dos vínculos familiares, reajuste de conduta ainda em parâmetros globalizantes não percebendo que a violências de gênero: simbólicas, estruturais e institucionais; variam de adolescente para adolescente e até mesmo no universo dessas adolescentes. Cada mundo a ser "reconstituído" terá uma abordagem especifica por conta da subjetividade que cada uma carrega, ou seja uma adolescente que vive na Ceilândia teve outros constructos que outra adolescente da mesma raça/etnia e até idade que vive 
também na Ceilândia teve. Os tipos de expressões/abordagens de intervenção social homogeiniza no cumprimento de medida de internação age de forma absurda coloca-as no mesmos padrões de "ajustamento" que os adolescentes do sexo masculino. Há por trás dessas expressões uma concepção formal de que a sociedade é um todo harmônico, cujo equilíbrio se mantêm pelo cumprimento dos papéis e expectativas que lhe são atribuídos pela cultura, pela religião e pelos chamados aparelhos ideológicos do Estado. (ALTHUSSER, 1980).

Estado esse que vive sob a égide do capital, que fora se estruturando com o fortalecimento mundial do neoliberalismo, os pré-requisitos para adentrar ao mundo globalizado modificam-se, criando uma situação que foi aceita sem contestações pelos presidentes da década de 90, que mobilizaram suas políticas públicas para a privatização, flexibilização das leis trabalhistas, valorização do capital especulativo, estabilidade monetária, contenção do orçamento, concessões fiscais aos detentores do capital e o abandono do ideal do pleno emprego (ANDERSON, 1995). Gastando bilhões de reais em políticas publicas que privilegiam grupos restritos (o caso do PROER é apenas um dos inúmeros exemplos citáveis), o Estado vitimiza o resto da população, criando diferenças inconciliáveis infligindo- lhe violências como a fome, a miséria e a exclusão social seja de classe, raça/etnia e ou gênero; que guardam intrínsecas relações com a delinqüência.

Com a obra "As metamorfoses da questão social", Robert Castel nos faz refletir sobre as novas formas da exclusão existentes na sociedade contemporânea. CASTEL (1998) aborda a questão social combatendo o termo exclusão social e introduz o conceito de vulnerabilidade com um caráter mais histórico e dialético, realçando a multidimensionalidade das relações sociais e a forma pela qual os sujeitos individuas e coletivos, são determinados instituindo esses processos e estruturas sociais. A vulnerabilidade para o autor resulta das particularidades assumidas pelo modo de produção e pelos modos de desenvolvimento que constroem cada sociedade nacional e envolve componentes básicos da organização social tais como “Estado, Nação, Cidadania, Trabalho, Etnia/Raça, Gênero, dentre outros”(CASTEL, 1998).

WANDERLEY (1996), retoma a noção de vulnerabilidade elencadas com os estados de privação e de não pertencimento, sob a lógica capitalista, a violência que as vulnerabilidades sociais estão submersas, tornou-se mercadoria, cuja produção, consumo e comercio gera lucros; tanto para os que praticam, quanto para os serviços e programas de enfrentamento que exigem respostas e soluções para as especificidades de uma das 
dimensões da Questão Social, tais como crianças e adolescentes, mulheres, pessoas idosas, doentes, deficientes, e outros grupos e segmentos em situação de vulnerabilidade, que se materializa no cotidiano da sociedade.

No caso do Brasil, a conquista (ou colonização) já enuncia a primeira dominação. $\mathrm{O}$ período colonial se caracteriza pela dominação burguesa, submetendo indígenas, camponeses, escravizando os primeiros, depois os negros. Formas assimétricas marcam as nossas relações sociais: desigualdades econômicas, de gênero, étnicas, religiosas, culturais. Na sua multidimensionalidade, a questão social se põe no Brasil como um problema de 500 anos, hoje agravado com as novas feições do capitalismo "globalizado". (VERAS, 2003)

Em sugestivo trabalho, L. E. Wanderley citado por CASTEL (1997) sinaliza com clareza:

\begin{abstract}
Minha tese é a de que a questão social abrange determinados elementos que historicizam a problemática geral, abrangendo outros componentes essenciais que serão aqui entendidos como partes constituintes do seu significado. Seminalmente ela vai emergir com o tema indígena e, logo após, com o tema da formação nacional, ainda que não sejam compreendidas assim pelos nossos olhos de hoje. E vai se desdobrando e se problematizando nas temáticas negra, rural, operária, da mulher (...) Mesmo no caso de sua convergência com a significação européia, por ocasião da implantação do capitalismo industrial no continente [latinoamericano], ela porém será fortemente condicionada por essas proposições histórico-culturais (...) mantendo especificidades (...) (CASTEL, 1997)
\end{abstract}

O atual capitalismo globalizado apresenta relações marcadas pelo mercado e pela oposição dialética entre capital e trabalho, que tendem a ser reproduzidas no aparelho de Estado, que as reorganiza de acordo com suas prioridades conjunturais e as executa através de suas políticas públicas. Estas, por sua vez, condiciona a vida dxs cidadãos (ãs), revigorando e fortalecendo o modo de produção. Através de suas políticas públicas o Estado abre um canal de comunicação, na maioria das vezes unívoco, com a sociedade, demonstrando e praticando sua ideologia, metas e diretrizes, num movimento que interfere e regula o fluxo da vida cotidiana. No desenrolar deste processo, que engloba desde a elaboração até a implementação destas políticas, há um choque entre os interesses que postulam ser contemplados, capitaneado pelo embate entre mercado e sociedade civil. (RASGA, 2001)

O Estado Brasileiro organiza as políticas públicas a fim de atender aos interesses do capital financeiro, a alocação de recursos para atender às demandas da sociedade civil fica 
gravemente prejudicada e restringida. O reflexo direto desta escolha é a queda de qualidade dos serviços públicos, que passam a prestar um atendimento insuficiente e de má qualidade, não sendo capaz de dar conta das necessidades e anseios da parcela da população que os procura, aqui no caso adolescentes infratoras.

No entanto, o Estado capitalista, que tem como característica fundante e distintiva (e portanto estrutural) o modo de produção baseado na utilização da propriedade privada para obtenção de lucro, ainda valoriza sobremaneira um único aspecto da complexa subjetividade do ser humano: o de consumidor. A dimensão da cidadania assumida pelas garantida pelas instituições do Estado é atrofiada, já que todos os desejos e aspirações individuais, bem como os direitos sociais, podem ser adquiridos comercialmente, desde que se disponha de capital suficiente (DINIZ, 1998).

A instituição do Estado aqui analisada é o CAJE, e está no mesmo prisma de governança da sociedade do capital, segue a lógica de coisificação mercadológica em um nicho de desrespeito as diferenças.

O desenho proposto pelo SINASE cujo o CAJE é subordinado, se correlaciona e demanda iniciativas dos diferentes campos das políticas publicas brasileiras. As reflexões teóricas e o exercício histórico das práticas sociais no sistema socioeducativo tem seguido uma lógica da igualdade de gênero, fruto de doutrinas neoliberais conflituosas e contraditórias, que produzem e reproduzem as desigualdades provocadas pelo sistema capitalista excludente e provoca permanentemente novas e diferentes manifestações da questão social $^{55}$. Essa situação paradigmática, que o Estado Brasileiro se encontra que não aperfeiçoa nem cria Leis especificas para atender as diferenças de gênero, respondendo de forma significativa na realidade social em que o gênero se apresenta. As reclamações dxs adolescentes são parecidas, mas têm traços específicos que mostram a forma com que o gênero, esse conjunto de conceitos e práticas culturais fundamentado a partir de uma diferenciação sexual eleita como forma de distinção mais básica de sujeitos, marca a trajetória infracional dessas adolescentes.

Para elucidar o citado acima podemos problematizar a necessidade do tratamento diferenciado respeitando as especificações do gênero com uma situação emblemática que foi

\footnotetext{
55 A Questão Social, conceito amplamente adotado na atualidade, refere-se basicamente à produção e distribuição de riquezas, e aos mecanismos de (dês)proteção social, tomando sempre o trabalho como eixo estruturante nas sociedades capitalistas, às relações sociais engengradas e às intervenções estatais reguladoras.
} 
outra denunciada feita pela ex-coordenadora da Casa de Semiliberdade (Gama-DF) Elionilde Ribeiro (2008):

"A impressão que tenho é que todas as questões concernentes as meninas infratoras são deixadas de lado, o Estado não tem a menor preocupação com o gênero e a desculpa medíocre do Estado baseada em seja nas questões orçamentárias (gasto público), seja quando se compara a quantidade "pequena" de adolescentes do sexo feminino em relação aos de sexo masculino; trava não só a construção de uma unidade de internação especifica para adolescentes do sexo feminino mas uma casa de semi também. O local que elas ficam no CAJE parece feito de improviso é apertado, pouco ventilado e não tem uma sensibilização do corpo profissional do CAJE para entender que até as oficinas e o lazer para as meninas tem que ter um agir diferenciado. Sem contar as questões de saúde publica que devem ser voltadas para uma educação sexual reprodutiva pensando em uma saúde integral, com visitas periódicas ao ginecologista, a instituição é patriarcal e não abarca nem de longe as especificidades de gênero; pode pergunta para qualquer interna como e quando elas vão no ginecologista não só nessa área de saúde mais em todas visando uma saúde integral"

Mesmo os Fóruns DCA`s, os Conselhos Tutelares, o CEDECA e o Ministério Público pressionando o Estado para a criação de unidades especificas de tanto internação quanto de semiliberdade (como já citato no último item do Referencial Teórico), o projeto elaborado em 2007 por Elionilde conjuntamente com xs promotores(as) da Vara da Infância de da Juventude Anderson Andrade e Selma Sauerbronn encontra-se parado no presente Governo Arruda; vislumbrando assim, uma outra questão emblemática que é o desprestigio das adolescentes infratoras pelo contingente (número) pequeno. Argumento sexista e reacionário que deixa essas adolescentes a mercê de uma política publica que ignora sua existência e não reconhesse sua fragilidade para o funcionamento das redes de proteção social. Existem muitos casos de meninas que estão internadas, mas são casos de semiliberdade assim como tem meninas que estão cumprindo liberdade assistida que são casos de semiliberade, ou seja elas ficam no extremo e tem direitos assegurados pelo ECA que são usurpados, ficando exclusas do tratamento garantido por lei.

Não podemos esquecer que a situação das adolescentes infratoras não é um estado social dado, imutável, estatísticas do CONANDA (2008) elucidam que aumentou em $20 \%$ a quantidade de adolescentes infratoras nesses dois anos últimos, esse dado reflete que a realidade é dinâmica e totalmente passivel à mudanças, os adolescentes sofrem as seqüelas de um processo secular e histórico das sociedades patriarcais que adquirem novos contornos e 
expressões no processo da globalização e dos programas neoliberais. Ultimamente, a defesa da igualdade dos direitos civis e políticos da adolescente infratora têm que ser manifestada como uma tentativa organizada de lutar pela equiparação incondicional dos gêneros quanto aos direitos humanos, refletindo um esforço por integrar as estruturas monolíticas do capitalismo e do patriarcado a uma nova visão desenvolvimentista e histórica, que discute a dominação do gênero e sua inter-relação com as classes, a etnicidade, a sexualidade, a política e a cultura (FUKUYAMA, 2000).

Segundo FRAISSE (1991), já no século XIX as mudanças ocorridas na economia, na sociedade como um todo e na política favoreceram o surgimento de discursos que levaram ao reconhecimento da desigualdade sofrida pelas mulheres e da superioridade imposta pelos homens. Esta situação refletiu especialmente o contexto e padrão cultural das medidas socioeducativas brasileiras, cuja orientação social, inclusive nas décadas recentes, reflete discursos e pensamentos que evidenciam a masculinidade (HOFSTEDE,1991) e o machismo (GOLDWERT, 1985 e TORRES, 1998).

\subsubsection{SOBRE ELAS: A construcão socio-cultural da categoria Gênero e seu impacto no CAJE - Perfil das Adolescentes e Demandas Institucionais}

Entendendo que o que será exposto nesse item terá relação direta com a Historia de Vida de Pagu, Anastácia e Bell, faz necessário a compreensão da construção sócio-cultural do gênero ao longo da historia tendo como alicerce as abordagens feministas para embasar o estado de opressão que as adolescentes infratoras do DF são acometidas no cumprimento de medida socioeducativa de internação. O conceito de Gênero é construído como categoria social que interfere no cotidiano das pessoas. Antes mesmo de nascer já são criadas expectativas para o novo indivíduo. A primeira pergunta a nova alma anunciada é: "É menino ou menina?" Da cor do quarto a escolha profissional, as oportunidades de vida já são construídas pela família que o espera. Sua suposta fragilidade ou virilidade já está construída no imaginário social familiar e será levado consigo por toda vida, tendo peso imponderável em suas escolhas pessoais. O Estado, na figura das instituições sociais materializa as formas hegemônicas de se relacionar por meio dos papéis a serem seguidos nas relações interpessoais.

Os primeiros ensaios e estudos sobre as desigualdades entre mulheres e homens buscavam se situar sobre o aspecto feminino, sobre seu corpo e sexualidade. As 
características biológicas, entre elas a pouca força física e até mesmo o menor peso do cérebro, estavam no centro desta concepção. Na tentativa de explicar que é da "natureza" feminina ser frágil e da "natureza" masculina ser forte. Que o lugar "natural" da mulher é a casa, e o lugar "natural" do homem é a rua. Esta naturalização da condição humana nada mais é do que uma resposta para legitimação das desigualdades sociais.

\begin{abstract}
“...Mais do que uma identidade apreendida, o gênero desta nova alma estará imerso nas complexas teias das relações sociais, políticas, econômicas e psicológicas entre homens e mulheres; relações estas que fazem parte da estrutura social institucionalizada da sociedade. Esta construção é dada através de processos de socialização e educação dos sujeitos para se tornarem homens ou mulheres e ainda, no estabelecimento dos padrões sociais entre eles. A teoria do status entende gênero como algo que ordenamos para fazer a vida social mais administrável. As pessoas aprendem a esperar certos tipos de comportamento e reações dos outros baseadas na sua categoria de sexo, respondendo aos outros baseadas no que acreditam ser esperado delas e assumem que os outros agirão da mesma forma. Essa teoria reconhece que os efeitos de gênero na interação social podem variar de situação para situação, podendo o gênero ser "ativado" mais em algumas situações que em outras... (WHARTON, 2005).
\end{abstract}

ACKER (2007), levanta outro ponto que merece destaque diz respeito à estrutura social. A noção de papel e a construção de gênero enquanto um set de atributos individuais dá mais atenção aos indivíduos do que a estrutura social, e sugere que o papel feminino e o papel masculino são complementares. Na teoria do papel sexual, movimentos pela mudança social, como o feminismo ou LGBTT, são movimentos pela expansão das definições dos papéis e para a mudança da expectativa desses papéis. Seu objetivo é expandir as opções de papéis para mulheres e homens, cujas vidas são constrangidas por estereótipos tendo como objetivo a redistribuição do poder na sociedade. Demandam realocação de recursos e o fim de formas de desigualdade que estão embutidos nas instituições sociais, bem como os papéis e estereótipos sexuais.

Dessa forma a instituição social aqui analisada o CAJE, carrega todos os vícios de uma construção sócio-cultural nem um pouco sensível a categoria gênero; imbicada de poder e como ela é dotada de poder que é propriedade de um grupo, e não de um indivíduo qualquer, está relacionado ao argumento de que gênero é tanto propriedade de instituições, como parte de nossas identidades individuais. As instituições criam padrões normativos de gênero, expressam uma lógica institucional de gênero e são uns dos principais fatores de reprodução da desigualdade de gênero; e fica nítido na fala de Pagu: 
"A cota de produtos de higiene/limpeza pessoal, nossa tem que ser diferenciada dos caras, nos menstruamos quando falta tem que por pão é? Porra é absurdo..." (Pagu, Interna do CAJE)

Neste caso, a identidade de gênero dos indivíduos molda as identidades de gênero das instituições, e as instituições expressam e reproduzem as desigualdades que compõem a identidade de gênero. No que se refere a esse tratamento "igual"; como afirma Pagu as diferenças para além de biológicas constroem está presente nos processos, práticas, imagens e ideologias, e distribuições de poder em vários setores da vida social. Tomando mais ou menos o funcionamento total, a estrutura institucional do CAJE e de outras sociedades são organizadas por linhas de gênero... (essas instituições) tem sido historicamente desenvolvidas por homens, geralmente dominadas por homens, e simbolicamente interpretadas do ponto de partida dos homens em posições vantajosas, no presente e historicamente. (WHARTON, 2005).

Desse modo, em um mês de convívio direto na instituição observou-se também que a estrutura arquetonica do CAJE é pensada apenas para os adolescentes sejam nas operacionalidades e condicionalidades do lazer/entretenimento a até mesmo para as oficinas. Fato comprovado quando vi que as garotas jogavam futebol o chamado "golzinho" popularmente conhecido em um local improvisado com aquelas traves pequenas em frente ao estacionamento interno bem próximo a entrada principal do CAJE. As partidas aconteciam logo depois do lanche vespertino. Como estava muito próxima delas, e sou uma mulher com indumentários bem diferenciado da "vestimenta do cadeião" ${ }^{\text {56 }}$ as adolescentes começaram a xingar e demonstrar hostilidade por estar assistindo a partida de futebol: "Patricinhas escrotinhas o que vocês querem aqui?"; "Vagabundas aqui não tem macaquinho enjaulado não?!. No mesmo contexto havia uma companheira de trabalho que trajava uma saia de tamanho grande com a estética "hippie" (anos 60), meus trajes eram customizados da moda street wear estilo hip hop, e as meninas atacaram de novo: "Crente filha da puta o que você quer aqui?"; "Sapatão filha da puta aqui tem vez pra você não!” Cantarolavam também alguns trechos de músicas do Facção Central ${ }^{57}$.

\footnotetext{
${ }^{56}$ Nome dado, por adolescentes de varias partes do Brasil, não só no D.F para o uniforme/farda ou padronização das roupas usadas nas Unidades de Internação.

${ }^{57}$ Grupo bastante conceituado no Rap Nacional, foi formado em 1991, na região central de São Paulo (Glicério, Cambuci e Ipiranga). conviveram desde a infância com violência social, tráfico de drogas, vícios, violência policial, delegacias e presídios. Um passado violento transformado em fonte de inspiração e traduzido em composições contundentes que relatam
} 
A contextualização da fala dessas adolescentes, não pode ser descolada do local das suas vivencias/ construções sociais que as mesmas foram adquirindo ao longo de suas vidas. O perfil das trajetórias infracionais das adolescentes é um tecido cheio de opressões e maus tratos. Elas não tem noção do que é ter direito a todos os bens e serviços que o Estado deveria garantir. As vozes nervosas, agressivas é a prova cabal de como essas meninas são puro ódio, elas não pertencem a essa sociedade posta. E não conseguem ver inicio, meio e fim para sua vida, dá uma noção que a qualquer momento sua vida pode acabar como eles/elas mesmo cantarolam: “O promotor é só um homem Deus é o juiz". "Não faço parte dessa merda toda, se vocês não querem dividir a riqueza nois vamo dividir nossa miséria".

Como afirma SALES (2007) em “(In)visibilidade Perversa - adolescentes infratores como metáfora da violência":

\begin{abstract}
"A cultura política engendrada no Brasil, da Colônia aos dias de hoje, não obstante momentos e movimentos de investimento na construção de vínculos civilizatórios, tem sido, marcada por: discriminações sociais, étnicas, de gênero, religiosas e culturais, polarização entre privilégios e carências, repressão, corrupção e autoritarismo, em razão estes últimos da forte penetração do Estado pelos interesses das classes dominantes"( SALES, 2007, p. 56)
\end{abstract}

Outra possível analise, ainda tendo como pano de fundo a fala das internas, é que essas adolescentes, consistem assim, num dos segmentos sociais que mais exprimem o estado da cidadania e do tratamento dos direitos humanos no Brasil hoje; e são alvos da violência social (MINAYO, 1994), expressa na falta de projetos de vida, no desemprego, nas dificuldades de acesso a serviços públicos de educação, saúde, cultura, esporte e lazer de qualidade,que se traduzem no que o CASTEL (1999) qualifica como negligencia planejada. Encontram-se, então, um estado de risco social as novas gerações - pessoas em desenvolvimento $^{58}$-- que não possuem autonomia e capacidade de auto-sustento, muito

a realidade cotidiana das camadas mais baixas da sociedade, além de criticar duramente aqueles que, na visão do compositor Eduardo, seriam os causadores dos problemas discutidos nas letras das canções (Griffos meus). Ameaças policiais por telefone, censuras de algumas rádios, prisões pelo conteúdo de algumas letras e até mesmo a proibição de veiculação na televisão brasileira do videoclipe Isso aqui é uma Guerra, considerado pelas autoridades como apologia à violência, são algumas das conseqüências decorrentes da postura do grupo.

\footnotetext{
${ }^{58} \mathrm{O}$ reconhecimento dessa condição peculiar remete ao respeito ao processo de desenvolvimento da adolescente com o aprovisionamento de condições familiares, sociais, ambientais e educacionais em cada etapa do seu crescimento, para que possam expandir suas capacidades individuais e sua sociabilidade (GUARÁ, 1995).
} 
embora estejam previstas na Constituição (Artigo 227) proteção integral $^{59}$ e prioridade absoluta, como responsabilidade do Estado, da família e da sociedade.

No CAJE, quando se trata da questão de gênero, há um capítulo que não se pode esquecer: as adolescentes pardas/negras: todas as adolescentes internadas eram pardas/e ou negras, pobres e moravam em cidades satélites extremamente periféricas ao centro. Há um grande desafio na questão gênero e raça/etnia, pois enquanto não houver a implantação de políticas públicas voltadas especificamente para esse grupo, a tão sonhada igualdade de gênero estará em um futuro muito distante, e os dados coletados no CAJE revelam que a implementação de uma política publica que leve em consideração a categoria gênero não pode ser desvinculada das questões raciais.

O diagnóstico da situação da mulher negra na sociedade brasileira contemporânea é um consenso construído pelas pesquisas publicadas pelos vários institutos - DIEESE, IBGE e IPEA - Levando-se em conta o IDH - Índice de Desenvolvimento Humano, a população branca se qualifica em $46^{\circ}$ lugar, enquanto a população negra em $148^{\circ}$, como se existisse dois países em um mesmo, o não - negro, desenvolvido, com acesso a educação, saúde, emprego, todos de boa qualidade, e o negro, sub-desenvolvido, com altos índices de criminalidade, mortalidade (principalmente materna e infantil), desemprego, péssimas condições de saúde e moradia.

A realidade socioeconômica brasileira, que tem rebatimento direto na realidade institucional do CAJE evidencia uma escala racial em que grande parcela da população negra permanece em situação de exclusão, e essa situação em relação à mulher negra/parda (CARNEIRO, 1995), como havia sido evidenciado pelas feministas, ao mostrar o entrelaçamento entre gênero, classe social e raça/etnia, agudiza-se ainda mais, ou seja, para as mulheres negras as desigualdades são potencializadas pelas discriminações que elas sofrem, restringindo-lhes as possibilidades de inclusão social. A ausência de recorte racial na análise do tema da violência, assim como em relação a outros agravos, tem dificultado a identificação das desigualdades a que estão expostas as mulheres negras/pardas.

Autores/as, principalmente os/as de grupos de feministas negras, começam a mostrar que há um agravamento das violências quando a mulher é negra, ocasionadas pelo racismo que gera outras violências adicionais. Tem sido observada uma vulnerabilidade maior da

\footnotetext{
${ }^{59}$ Constitui o novo paradigma de atendimento às necessidades da população infanto-juvenil, em que todas as crianças e adolescentes são sujeitos de direitos, rompendo com a doutrina da "situação irregular" do menor, nesse viés leva-se em conta as necessidades integrais para além das suas necessidades básicas (Idem, 1995)
} 
população negra no que diz respeito a agravos crônicos e menor expectativa de vida, com escores menores no índice de desenvolvimento de gênero que mede desigualdades entre homens e mulheres.

Os índices educacionais das internas do CAJE é baixo, variam entre a quinta serie e a oitava serie do ensino fundamental. O principal fenômeno que contribui para a evasão escolar é o envolvimento infracional cedo, tornando-se um mundo muito mais atraente por que passa a ter aplicabilidade política na vida dessas adolescentes que conseguem em sua grande maioria trabalhando no trafico de drogas fonte para seu sustento. A realidade no CAJE também não é diferente como já foi citado no Referencial Teórico, as aulas tem dias que tem e outros dias não são dadas. E quando oferencem as aulas são dadas de qualquer forma sem a menor preocupação com o rendimento nem com o estabelecimento de vínculos. Pagu, Anastácia e Bell entendem a importância de ter "educação", mas acham a aula chata e enfadonha:

“Que diabos que o pretérito perfeito vai mudar na minha vida? Eu estou pensando é nos meus corres quantos papelotes vou ter que vender nas correrias $e$ sempre matava aula nas toras não conseguia nunca voltar depois do intervalo..." Pagu, Interna do CAJE, 18 anos.

Quanto aos cursos profissionalizantes que o CAJE oferece, são sistematizados através de oficinas, demonstram que só carregam o nome profissionalizante pois são ineficientes visto que quando os adolescentes terminam sua execução eles não vêem retorno e utilidade prática em sua vivencia fora do CAJE. Os cursos acabam funcionando como oficinas para passar o tempo.

“...Essa escola e essas oficinas não servem de nada são só passatempo e um meio de sair da cela...” Anastácia, Interna do CAJE, 17 anos.

“... Fazer esse curso de Padeira o que vai servir isso na minha vida com os meus corres te garanto ganho muito mais, e ainda corro o risco de ser humilhada quando forem fichar minha carteira e ver que fiquei presa aqui, vou só para passar o tempo, aqui é só neurose...” Pagu, Interna do CAJE, 18 
Para além da aplicabilidade dos cursos profissionalizantes, depois da saída do CAJE, essas adolescentes sofrem com o estigma de serem ex-internas o peso da palavra infratora, marcadas a ferro. Percebo o CAJE como uma prisão, e mesmo tendo todas as legislações como o SINASE por exemplo, ele não funciona como uma medida socioeducativa. A prisão em sua história favorece a socialização em uma cultura carcerária, o sistema prisional brasileiro não está comprometido com a questão da ressocialização, como se infere a partir da ausência de políticas voltadas para tal objetivo. Este modelo, está voltado para aquelxs que estão fora dos presídios, visando a garantir sua segurança ao privar da liberdade aquelxs pessoas considerados "perigosxs" para a coletividade.

\begin{abstract}
$\mathrm{O}$ atestado de antecedentes criminais ${ }^{60}$ faz com que a condição de homem/mulher em débito com a justiça, na maioria dos casos é atribuída pela simbólica representação negativa ao seu portador. Como a sociedade não confia na eficiência do modelo disciplinar e pedagógico das prisões, por não cumprirem o seu papel ressocializador e reeducador, a visão desse documento gera uma tensão, tanto para quem o apresenta como para quem a ele é apresentado, representando assim um documento oficial de estigmatização. (GOFFMAN, 1988)
\end{abstract}

A sociedade como um todo (Estado e sociedade civil) tem sua parcela de responsabilidade na reinserção social dos (as) egressos(as). Este problema não pode ser visto como única e exclusivamente da responsabilidade do ente estatal, tendo em vista as suas limitações organizacionais para implementar de modo efetivo e total a reinserção social. Por mais que o Estado efetue, por exemplo, cursos profissionalizantes dentro do cárcere, sua reintegração à vida social não será efetiva se não tiver oportunidade no mercado de trabalho. (SANTOS, 2003)

Contudo, no momento que a interna termina o cumprimento da medida, encontra-se em situação de vulnerabilidade, dado que não ocorre o processo de ressocialização e preparação para a reinserção social, o estigma que agora carrega amplia as dificuldades para a sua reinserção. $O$ fato de não existirem políticas públicas que auxiliem as ex-internas no seu processo de reinserção torna a atuação da sociedade civil indispensável. E a importância da reintegração social da interna para toda a sociedade, surge na medida em que é um dos principais meios de impedir a reincidência, onde o apoio da família é indispensável.

\footnotetext{
${ }^{60}$ Para o referido TCC lesse Ato Infracional visto que criança e adolescente não comentem crime e não são legislados pelo código penal e sim pelo ECA.
} 
A vida das três adolescentes (Pagu, Anastácia e Bell) assim também como as demais, que não entraram como objeto de estudo deste TCC, são as outras formas de reajanjo familiar; da qual elas fazem parte. A instituição familiar, encontra-se totalmente esfacelada não existindo o vinculo necessário de cuidado e proteção como um dos pilares para a formação sócio-cultural dessas adolescentes, das três a somente a Anastácia teve o vinculo com a mãe. Na família de Pagu e Bell tem uma inversão dos papéis sociais. A avó tem de assumir o papel de mãe desta família. Com isso, entende-se que, de uma forma ou outra, a família da interna também está presa, e não está preparada para enfrentar a perda de um membro alicerce da mesma.

A família sofre alterações também de natureza cultural, o que não seixa de ser um produto mesclado daqueles processos, mas a capacidade de neles interferir. Dentro disso, tem-se a ruptura de velhos padrões de vida familiar, com transformações significativas nos papeis de gênero e nas obrigações para jovens com velhos. O reajanjo da sua estrutura em decorrência de fatores econômicos e culturais vem gerando um formidável vazio institucional, na medida em que é escasso o suporte social para além da família. Este quadro aponta, assim, uma crise geral do modo de cuidar dos dependentes e de promover a interdependência no mundo de hoje enquanto responsabilidades outrora básicas da família. Aqui este processo se dá concomitantemente ao esgarçamento do já precário padrão de proteção social (PISCITELLI, 2002).

Ainda tem outro agravante na historia de vida dessas meninas todas as três tem histórico de violência/abuso sexual; a mãe de Pagu era prostituta e ela faleceu quando ela tinha 5 anos, morou um tempo com a avó também prostituta que faleceu 4 anos depois, em ela foi morar com o "suposto" pai que a violentava, batia e abusava dela com frequiência os dias; a Bell é órfã morou muito tempo em casas abrigo e orfanatos até que descobrissem o paradeiro da avó dela, depois de descoberto foi morar com ela e tios que também a violentava e abusava sexualmente dela; e por fim, Anastácia igual a família dela encontrava a vida da grande maioria das adolescentes internadas, pai alcoolista mãe empregada domestica família grande com 5 a 6 irmãos (as) pobres e o pai a violentava constantemente.

"Exaltado como expressão de beleza, inspirador do desejo, fonte de prazer, de vida - através da maternidade -, símbolo da nação republicana - na França pós-revolucionária, como no Brasil -, o corpo feminino é também lugar de violência física - espancamentos, estupros, etc - tão bem conhecida, sejam aquelas outras formas de violência sutis, engenhosas, entre as quais a chamada violência simbólica, que 
igualmente, contribui para a manutenção de desigualdades." (LOURO, 2002, p. 14)

Nesse sentido mesmo que tenha o atendimento psicossocial no CAJE, não existe um tipo de capacitação/sensibilização da equipe que fará o atendimento das adolescentes voltados para um viés de intervenção sensível a percepção da violência de gênero, visando o enfrentamento da cultura patriarcal e machista, e faz-se necessário a implementação de políticas transversais que atuem modificando a discriminação/opressão e a incompreensão de que os Direitos das Mulheres são Direitos Humanos.

Analisando com cuidado os pareceres sociais contidos nos processos de Pagu, Anastácia e Bell não foi feito um acompanhamento para perceber as seqüelas, os traumas e os medos que carregam por conta da violência sofrida. Esse processo de não ter um acompanhamento especifico para as vitimas de violência sexual constiui uma falha institucional desvelando mais uma vez o que vêem sendo comprovado ao longo do TCC aqui desenvolvido. Conceber os efeitos dessa violência também faz parte de um contexto social mais amplo, pois as seqüelas físicas e psicológicas por ela produzidas têm se tornado mais visíveis com a socialização da discussão do fenômeno (LEAL, 2007). Sabe-se hoje que as mulheres atingidas ficam mais vulneráveis a outros tipos de violência, à prostituição, ao uso de drogas, à gravidez indesejada, às doenças ginecológicas, aos distúrbios sexuais, à depressão, ao suicídio e às infecções sexualmente transmissíveis. (Ministério da Saúde, 2008)

A atenção às vítimas de violência sexual no Brasil é recente, uma vez que a questão da violência teve sua conceituação delimitada no termo 'violência doméstica', ressaltando das agressões físicas e maus-tratos conjugais no âmbito da família, encobrindo a relação entre sexualidade e violência nos espaços públicos e privados no Brasil. Destaca-se a atuação do Fórum Interprofissional sobre Atendimento da Mulher Vítima de Violência Sexual e o movimento feminista como fundamentais para a elaboração de políticas públicas em duas áreas chaves: a saúde e a violência. Mas, até recentemente, as políticas públicas dirigidas à violência de gênero se voltavam para a área jurídica e a criminalização do agressor. Neste sentido, destacam-se as DEAMs, que, até 2003, somavam 307 no país, e a atuação de muitas ONGs de mulheres e direitos humanos que se dedicam a este problema. (MELO, 2007). 


\subsubsection{ELAS X ELAS: A Historia de Vida de Pagu, Anastácia e Bell - Diários e}

\section{$\underline{\text { Relatos }}$}

A categoria delinqüência aqui é entendida como umas das mais ricas para dimensionar a força do discurso dominante, a ponto quase de se sentir a sua vibração policial e de se poder apalpar a sua intensidade de verdade jurídica. Como diz GROS (2004), inspirado em Foucault, a sociedade capitalista funciona mais à base da verdade que da lei. Verdades que pesam como incontornáveis e indefectíveis leituras do real, como as da criminalidade e da delinqüência, e das pessoas que nele se movem. Verdades que suscitam atitudes de sujeição, estigma e preconceito (SALES, 2007).

Nem herói (na) nem de todo vilão (ã), subsiste em tudo isto o ser humano, que para Foucault, é um(a) ser errante, que não se encontra jamais totalmente em seu devido lugar e que invariavelmente, também comete erros, estando destinado a conviver com verdades que não são de todo falsas nem totalmente verídicas (VEYNE, 2004).

Então a questão da delinqüência e as formas de sua exposição à visibilidade também se submetem a esse viés. Que ela existe é fato. Agora como se lê esse processo, o que se diz e o que mostra dele faz com que como alerta MUCHIELLI (2002), por vezes, leituras sensacionalistas, escudadas em argumentos repressivos e impulsionadas por motivações políticas conjunturais, maximizem efeitos e consequiências, prevalecendo sobre a realidade do fenômeno. É o caso de lembrar que visões ditas "miserabilistas" podem também distorcer a realidade par baixo, isto é, enxergar e dar a ver menos a violência do que ela realmente existe, e, enquanto tal, requer medidas e providências.

Nesse sentido, em conformidade com SALES (2007), o papel dos (as) e do conjunto de entidades e atores que integram a luta por direitos de crianças e adolescentes consistiria não em falar pelas adolescentes infratoras, mas em contribuir para que a pluralidade dos discursos relativa à critica da situação que lhes concerne venha à tona. Trabalhar pelo direito à palavras delas, recusando sempre o papel de "recuperadores complacentes de pessoas sem voz” ou a intenção de elevá-los ao mesmo nível de discurso nosso. Trata-se de trabalhar "pelo direito à guerra de discursos".

\section{Pagu - Diários e Relatos}

Estatura mediana, cabelos compridos amarrados, olhar centrado e sorriso pequeno. Perdeu sua mãe muito nova com 5 anos de idade, depois da morte de sua mãe foi morar com sua avó materna, tanto a mãe quanto a avó 
eram prostitutas. Depois de 4 anos morando com a avó a mesma falece,durante dois anos ficou sendo mandada de casa para casa de varias tias irmãs da sua mãe até que descobriram o paradeiro de seu pai e até o ano da Pesquisa “CAJE HOJE” 2006 ela não tinha certeza se ele era mesmo seu pai. Não suportou morar com ele nem ano e voltou para as casas das tias em Ceilândia. "Meu pai bastardo chegava bêbado me batia obrigava a cozinhar pra ele preparar a janta depois ficava me alisando, gozava na minha e frente e fazia coisas piores que prefiro nem falar". Aos 11 anos comete seu primeiro roubo: "Quando o carro era mamão, era eu que cantava a micha (a micha 'canta' quando faz um barulhinho característico, como um metal raspando em outro, ao abrir a porta)." Paralelamente a roubos e furtos entra para o movimento da boca perto de sua casa, e começa a passar papelotes de merla, cocaína e maconha. Período esse 12 para 13 anos que começa a fumar maconha: "Então dei a primeira bola e notei imediatamente que minha boca e minha garganta adormeceram. O coração disparou. Minhas mãos ficaram tremendo. (...) Eu tinha a impressão de escutar tudo muito longe." Dos 13 para os 14 anos foi sentenciada umas 7 vezes por furto, roubo, tráfico de drogas nas primeiras vezes foi somente advertida depois sentenciada para o cumprimento de liberdade assistida. "Nós roubávamos todos os boyzinhos que encontrávamos pela frente. Ás vezes não precisava nem sacar o revólver. Bastava mostrar o cabo erguendo a camiseta. Eles tremiam na base! E já tiravam o boné, o tênis e até trocavam de roupas com a gente, dependendo do local." Passa o tempo e seu envolvimento com o trafico de drogas cresce a tal ponto que aos 15 anos passa a ter sua própria boca de fumo, sai da casa das tias e aluga sua própria residência com o dinheiro conseguido na boca, que tinha um movimento grande, de acordo com o processo dela no CAJE ela era uma liderança no trafico de drogas da Ceilandia. "Os viciados chegam a trocar tênis, bermudas e camiseta por nóia. (...) Eu mesmo já vi pai de família fumar o dinheiro do leite das crianças e até o enxoval do neném; do bebê dormir em carrinho, em vez de ter um berço. Já vi meninas grávidas trocando roupas de neném por nóia. ..." Até o dia que armaram uma embosca para tomar a boca dela de assalto ela se feriu e ainda foi mandada para o CAJE, privada da sua liberdade por 3 anos; quando entrevistamos ela para a pesquisa ela tinha 1 ano e dois meses de cumprimento da medida de internação. "O moleque então armou uma casinha (ou seja, uma emboscada) para que um outro cara, chamado Deílton, me catasse e me desse umas facadas."

De forma muito expressiva Pagu apontou três grandes falhas institucionais do CAJE referentes à escola, a disponibilização dos produtos de higiene e limpeza e aos cursos de profissionalização; que já foram contextualizada acima. O É mister, portanto, que se a sutileza das diferenças de gênero na sociedade estão intimamente ligadas à influência da ideologia e do discurso (Oliveira, 1998), a teoria feminista (ela que norteia todo o TCC) argumenta que as políticas públicas são necessárias a fim de modificar as práticas pelas quais as instituições, aqui no caso o CAJE se afastam da categoria gênero em seus métodos interventivos de convívio social. Segue ainda uma outra analise, o reconhecimento de que as tensões e contradições sociais para adolescentes infratoras são invisibilizadas, freqüentemente a mídia só visibiliza noticias ligadas a infratores do sexo masculino, logo como espaço estratégico de publicização de temas de interesse coletivo, os órgãos e profissionais da mídia devem estar cientes das implicações das imagens e palavras veiculam. Divulgas fatos sob a grande missão do testemunho social-historico, increve-se o poder discursivo de tecer verdades, submetidas, por vezes, as tiranias da comunicação e noutras, à fragmentação. (ANDI 2008).” 


\section{Anastácia - Diários e Relatos}

Olhar cansado, cabelos encaracoladinhos e fala forte esse são os traços mais marcantes de Anastácia, que como já exposto no item acima a família de Anastácia é o raio X muito semelhante a situação que muitas adolescentes se encontravam internadas. Pai alcoolista mãe empregada domestica família grande com 5 a 6 irmãos (as), pobres e o pai a violentava constantemente. "Fiquei desesperada vendo minha irmazinha mais nova - Andressa - chorando de fome, e meu irmãozinho - Lucas- querendo leite. "Começou a fumar maconha aos 11 anos. "Com alguns meses andando direto com os caras que fumavam mesclado, em vendi até minha bike em troca de uma quantidade de pedra (nóia); e tive meu primeiro contato com a nóia pura, queimado no cachimbo ou em latas de refrigerante, e passei a furtar para manter o vício" Logo depois sua trajetória infracional se inicia, começa a roubar e traficar drogas, com esse dinheiro compra uma arma e coloca o leite em casa dos seus irmão menores. A incidência aumenta dos 13 para os 16 anos e o período que melhor desfruta da sua adolescência sempre com dinheiro para sustentar seus programas, entre uma sentença e outra de liberdade assistida ela vivia muito bem.

"...chegávamos nas barracas da feira e "ganhávamos" as caixas dos comerciantes e até as carteiras das pessoas que estavam comprando... furtávamos tudo o que podíamos levar. Tudo isso era para curtir o os Bailes de Rap no Tropical em Tagua eu que morava lá em Planalta não tinha tempo ruim ia mesmo nas toras sempre nos sábados à noite, me amarro em Tropa de Elite onde tinha show dos caras eu ia mermo!Saudade desse tempo bom" Destemida e extremamente fria tinha total domínio sobre o que falava demonstrava experiência e segurança. Rodei por causa do roubo da farmácia, vacilo total. "Eu precisava de dinheiro para pagar um cara que passava maconha. (...) O assalto foi numa farmácia. (...)Na minha cintura tinha um 38 e na do meu marido - Kleitin- parceiro de 1 ano de namoro uma garrucha 38. (...) Eu ficava o tempo todo pensando "Vai chover polícia!" e Rodamos ele é de maior 22 anos e já tinha puxado cadeia aqui no CAJE foi pra PAPUDA ${ }^{61}$. Ela relata a vontade de casar com Kleitin, e ainda fala com um desprezo do CAJE, denuncia que o tempo que ela estava lá quase dois anos nada mudou na vida dela pelo contrario só cresceu mais as revoltas com o mundo e com a vida. "Aqui é só descaso é essa escola dia sim dia não nem com as oficinas consigo ocupar minha mente, mas já esta acabando e vo tomar muito cuidado lá fora".

Anastácia fez as mesmas criticas ao CAJE que Pagu fez; o que diferenciou sua fala foi sobre o tratamento medico hospitalar que a Unidade disponibiliza. "Qualquer coisa que sentimos dão um remedinho para nós e se gritávamos pedindo médico de verdade alegam que estamos "nervosas, como é o caso de cólicas menstruais tão é aspirina pra gente pode contorcer de dorque eles não fazem nada... dão um acalma leão que ficamos grogues e durmimos o dia todo eu boto fé que é algum tipo de sedativo só pode. Eu tenho um dente que dói, mas não tem tratamento aqui. Tudo que eles fazem é arrancar o dente fora". Tem um médico aqui mas não tem remédio; eles não dão nenhum remédio..."

É notório que o tratamento tem que ser diferenciado e sensível ao gênero Apesar das internas geralmente necessitarem de mais cuidados médicos do que os internos, por conta das suas diferenças sexuais/biológicas a assistência médica é, com freqüência, extremamente deficiente no estabelecimento do DF de internação feminina. O CAJE não possue médicos ou enfermeiros fixos vão poucos dias da semana. Para atender as necessidades de assistência médica das internas, a instituição normalmente conta com os medicamentos mais

\footnotetext{
${ }^{61}$ Nome do Complexo Penitenciário do Distrito Federal
} 
básicos, como aspirina, creme para pele e remédio para o estômago. As internas mais doentes (como o caso de Anastácia) reclamam que raramente são conduzidos a postos de saúde para tratamento médico, afirmando ser muito difícil, se não impossível, convencer as autoridades de que eles precisam ser levados a tais estabelecimentos. "Não adianta pedir"

Cabe salientar, neste sentido um importante dado que foi coletado quando fizemos a visita orientada na Unidade de Internação analisada, que ilustrou algumas das deficiências do tratamento médico oferecido no CAJE; desrespeitando o que é convencionado pelo SINASE:

a) espaço físico inadequado, incompatível com a prática de atividades médico-sociais;

b) distribuição inadequada de enfermeiros e seus assistentes, que não possuem o treinamento básico para exercer algumas de suas atribuições, especificamente o tratamento de doentes mentais e de atenção especial às internas;

c) inexistência de fundos mensais o que causa a falta de medicamentos básicos e resultam no comprometimento da saúde do (a) paciente;

d) falta de equipamento técnico para facilitar o atendimento básico de emergência.

\section{Bell-Diários e Relatos}

Menina, tímida olhar desconfiado extremamente agita e bastante na dela "caladona". Bell é órfã morou muito tempo em casas abrigo e orfanatos até que descobrissem o paradeiro da avó dela, depois de descoberto foi morar com ela e tios que também a violentava e abusava sexualmente dela; e por fim, "...na falta de um pai ou de um padrasto e, na ausência de minha mãe, o 'homem' de casa era eu, que tinha apenas 6 anos." Depois de não suportar mais tanta violência que passava com os tios decide ir em casa visitar a avó as vezes e passa a morar na rua fazendo suas correrias seja com o trafico de drogas seja com furto e roubo. “ A cultura das ruas é diferente cada um garante o seu.. com toda confusão que era minha vida aprendi não se podia confiar em ninguém. Esta foi a primeira coisa que eu aprendi desde o dia que sai da casa da minha avó em Taguatinga. A segunda é que eu tinha que andar armada, ou com os caras e as minas que faziam as fitas erradas (as fitas são os roubos e furtos) para ser respeitada. E, terceiro, não se fica devendo droga para ninguém, especialmente aos traficantes. Ainda há uma quarta regra: não se deve envolver com qualquer cara, pois havia muitas mulheres de ladrão que entrava numas; e se envolver com qualquer uma deles era morte na certa." A condição de Bell perpassa por todas as violências institucionais ${ }^{62}$ possíveis e imaginaveis (física, psicológica, sexual e da negligência) resultando, na maioria das vezes, em seqüelas bio-psíquicas irreversíveis. "Na rua você ver de tudo e eu via tudo aquilo e nem ligava. Tudo alí parecia normal: fumar um baseado na rua, a molecada cheirando cola, as meninas fazendo sexo com uma 'pá de caras' (sexo grupal). E eu alí no meio daquele furacão." A trajetória infracional de Bell mostra que ela já tinha cumprido medida de internação referente a semiliberdade aos 14 anos ficou 6 meses internada e volta em 2006 para cumprimento de internação no período da pesquisa ela tinha 2 meses de cumprimento o motivo da entrada na unidade foi trafico de drogas.

\footnotetext{
${ }^{62}$ Adota-se o conceito de Deslandes (1994), a qual define a violência contra as crianças e aos adolescentes, ou os maus-tratos, como prefere a autora, "pela existência de um sujeito em condições superiores (idade, força, posição social ou econômica, inteligência, autoridade...) que comete um dano físico, psicológico ou sexual, contrariando a vontade da vítima ou por consentimento obtido a partir de indução ou sedução enganosa".
} 
O contato com Bell e as denuncias feitas por ela seguem a mesma linha dos relatos de Anastácia e Pagu;o que demonstra que elas estão alinhadas e que a realidade no tratamento de adolescentes infratoras sofre de um descasso total de uma política publica que abarque suas especificidades.

É preciso porem, ponderar que Bell assim como as outras duas adolescentes (Pagu e Anastácia) sofreram omissão dos pais ou dos responsáveis no atendimento às necessidades básicas e no encaminhamento de seus direitos fundamentais. A omissão para com os cuidados básicos com a saúde, alimentação, higiene; a falta de inserção das adolescentes em idade escolar na rede de ensino; a ausência do registro de nascimento; a falta de vacinação; o descuido com a atenção à criança gerando acidentes ou situação de rua; são exemplos mais comuns de negligência registrados nas unidades de internação; tanto é que Bell é semi-analfabeta, Pagu fez até a quinta serie do ensino fundamental e Anastácia até a oitava serie.

Apesar de atingir de forma particular as mulheres pardas/negras, pobres e moradoras das cidades satélites do D.F tal violência também se verifica em todos as culturas e classes sociais. A visibilidade maior nas camadas populares é possível, devido estas, em termos absolutos, serem maior numericamente e por utilizarem mais os serviços públicos de saúde e educação. Enquanto que as classes médias e altas, ao contratarem os serviços privados, beneficiam-se também da omissão de notificação dos casos e da falta de maior monitorização das autoridades nestes estabelecimentos.

Para finalizar, outro ângulo a ser destacado, pode-se dizer que as análises sobre a violência contra adolescentes infratoras devem considerar a inter-relação entre diversos fatores (econômicos, sociais, culturais, psicológicos...), sem definir uma determinação linear de aspectos macro-estruturais sobres os casos acima registrados. Entre os diversos determinantes, considerados em inter-relação, destacam-se:

$\rightarrow$ Econômicos - carência material para garantia de alimentação adequada e de outras necessidades básicas (desemprego; baixo salário; ausência de benefícios assistenciais); ausência de investimento em equipamentos sociais ou dificuldade de acesso (creche; serviço de saúde; escola; transporte; habitação; saneamento básico...); trabalho informal dos pais desprotegido e com intensa carga horária. .

$\rightarrow$ Sociais - alcoolismo e abuso de outras drogas; omissão da paternidade; gravidez indesejada; gravidez na adolescência, podendo resultar no despreparo ou na maternidade mal-assumida; sobrecarga de atribuições e de papéis sociais (mães chefes de família); desconhecimento sobre as fases de desenvolvimento da adolescente

$\rightarrow$.Culturais - papeis sociais que reforçam estigmas e preconceitos e mantém a dominação patriarcal sexista em uma sociedade cada vez mais voltada para transformar as relações humanas em mercadoria, repetição da educação recebida, reproduzindo os conceitos de "castigo", "hierarquia", "autoridade", "respeito", "sucesso", "disciplina"...; reprodução de valores pelos profissionais de saúde (violência institucional), resultando no despreparo para o atendimento da família ou na omissão da notificação; concepção de que os filhos são 
propriedade dos pais; visão de dominação do mais forte, esta difundida no interior da família e da comunidade.

$\rightarrow$ Psicológicos - frustração pessoal dos pais (no trabalho, na relação conjugal, na vida comunitária, consigo mesmo...); frustração dos pais sobre a expectativa sobre o comportamento dos filhos (personalidade e temperamento incompatíveis ao dos pais), gerando a desqualificação das filhas ou a comparação entre os mesmos; filha não desejado ou fruto de relação frustrada, cobranças sociais que os papeis sociais carregam "coisas de meninas" "coisas de menino"

$\rightarrow$ Biológicos - distúrbios psiquiátricos dos pais; doenças crônicas ou deficiência física ou mental dos filhos, causando sobrecarga dos pais na atenção necessária; doenças crônicas dos pais que dificultam a atenção aos filhos; stress dos pais, envolvimento com álcool.

$\rightarrow$ Históricos - mudanças do modelo de família; mudança no papel feminino na sociedade; não há um recorte nem que minimamente construído em relação ao comprimento de medidas socioeducativa no D.F; avanços na legislação de proteção à criança e ao adolescente, tornando mais visível os casos de violência.

4.1.1.3 MIOPIA DO ESTADO: Ausência de uma Política Pública de gênero no CAJE como opção política.

A formulação de uma política pública, que supõe exigências diretas sobre o Estado, tem sido buscada por muitas feministas. Os temas englobados nessas exigências são a igualdade de status para as mulheres, a remoção da discriminação sexual, a introdução de regulamentos contra assédio sexual e a introdução de cotas que garantam a representatividade feminina. (LOURO, 2002)

Entretanto, não existe um consenso, dentro do movimento feminista, em relação ao papel do Estado nas relações de gênero. O grupo geralmente caracterizado como "feministas liberais" considera que o Estado é neutro e corrigirá desigualdades de gênero quando lhe forem fornecidas informações pertinentes sobre as disparidades existentes. Um outro grupo, compreendendo feministas com perspectivas "radicais" ou "socialistas", está mais inclinado a considerar o Estado como uma instituição patriarcal que reflete divisões de gênero ao mesmo tempo que as produz. No estudo aqui em questão entende-se o CAJE é análogo a essa situação e opera de forma patriarcal.

Nessas situações, as mulheres são geralmente excluídas de um acesso direto aos recursos estatais devido a sua ausência nos departamentos estatais e, de forma indireta, por forças políticas "sexistas" que atuam sobre o Estado (PATEMAN, 1993). 
O Estado molda as relações de gênero através de regulamentações relativas ao divórcio, ao casamento, ao aborto, à anticoncepção, à discriminação salarial, à sexualidade, à prostituição, à pornografia, ao estupro e à violência contra a mulher (WALBY,1990). Entretanto, a natureza patriarcal do Estado não é considerada estática. Afirma-se que forças dominantes modernizaram a posição feminina ao permitir a participação plena das mulheres no mercado de trabalho. Mas, simultaneamente, o Estado tem neutralizado as exigências feministas através de várias concessões as quais, embora melhorem a situação, não eliminam os obstáculos fundamentais para a igualdade feminina o princípio de igualdade de oportunidade em vez de reconhecer a necessidade de uma educação antisexista seria uma alternativa viável, pois a construção social do gênero daria de forma mais equânime. (YATES, 1993)

Com o tempo, a posição feminista de distanciamento do Estado evoluiu para a utilização de uma estratégia dupla: trabalhar com o Estado através de pressões e desenvolver um trabalho independente através de grupos de mulheres, particularmente organizações nãogovernamentais (ONGs). Essa nova postura passou a existir como conseqüência do reconhecimento de que as mulheres tem maiores chances de aumentar sua influência no processo político - em alianças com homens que apóiam a causa e fazem lobby pelos interesses das mulheres — do que através do mercado ou das ONGs, que tendem a ser pequenas e fragmentadas (FUJIWARA, 2002).

Numa apreciação do comportamento do Estado Brasileiro, as teóricas feministas observaram que as políticas estatais nem sempre tendem para o status quo. Enquanto os Estados consideram a mulher e a família como um duo inseparável, no qual os problemas de uma se tornam os problemas da outra, com frequiência assumem políticas públicas contraditórias em relação às mulheres. Por um lado, a necessidade de contar com elas como sendo mães e esposas induz o Estado a formular projetos muito convencionais nas linhas de gênero. (FUJIWARA, 2002). No CAJE a posição assumida revela uma miopia evidente mesmo existindo, tendências globais a favor de normas democráticas obrigam os Estados a oferecer direitos iguais para todxs xs cidadãs. Essas contradições criam janelas de oportunidade para possibilidades de transformação e ação organizada.

Dessa mesma forma, a ampliação do papel dos governos subnacionais, (Governo do D.F na figura do Estado) na formulação e implementação de políticas públicas nos últimos anos foi acompanhada pela inclusão de novos temas no campo de atuação dos governos 
estaduais e locais. Entre esses novos temas, inclui-se a questão de gênero. Tendo por base o conjunto de analise de dados contidas neste trabalho, verifica-se que essa inclusão não tem se dado nem ao menos por meio de programas dirigidos à mulher do que pela incorporação da dimensão gênero em uma Unidade de Internação que não têm a mulher como foco específico.

Tal incorporação nem sempre significa, no entanto, 'aderência' à agenda de gênero ou incorporação da perspectiva de gênero, entendida como uma ação que promove a redução de desigualdades entre homens e mulheres. Há programas que, embora focalizem as mulheres ou a elas dirijam módulos específicos, acabam por reiterar desigualdades de gênero, reafirmando uma posição tutelada e subordinada da mulher tanto no espaço público como no privado vertente - hegemônica na agenda dos movimentos de mulheres no Brasil - tem por base a perspectiva de direitos. (FARAH, 2002)

Segundo essa vertente, trata-se de garantir a ampliação do espaço da cidadania, pela extensão de direitos a novos segmentos da população e pela inclusão desses novos segmentos na esfera do atendimento estatal. As iniciativas da área de medidas socioeducativas de internação nem mesmo na área de saúde adotam a perspectiva de atenção integral e os programas de combate à violência contra a mulher parecem ser tributários dessa perspectiva, na maior parte dos casos. Mas o 'alinhamento' dos programas/ instituições a uma dessas principais vertentes (de direitos) da agenda de gênero nem sempre ocorre. Por exemplo, no caso dos programas de geração de emprego e renda, a priorização das mulheres é defendida tanto pelos que enfatizam o impacto desse apoio no combate à pobreza como pelos que enfatizam a busca da autonomia das mulheres, vítimas da pauperização.

As políticas e programas brasileiros já institucionalizados com questões transversais ou centrais que visibiliza a sensibilização do gênero, permite que o CAJE, assuma de forma compromissada pelos marcos regulatórios e pelo exercício da atenção integral para essas adolescentes infratoras, parecem sugerir que, entre a invisibilidade das mulheres e de suas necessidades e demandas e uma ação governamental resultante de uma 'consciência de gênero', que incorpore a perspectiva de gênero de forma sistemática e generalizada, há um terreno intermediário, associado a um processo incremental de transformação, em que alguns temas da agenda de gênero e algumas das abordagens propostas por movimentos e entidades de mulheres são incorporados, de forma gradual, abrindo talvez caminho para transformações mais profundas. 
Nesta perspectiva, pode-se dizer que o Serviço Social se institucionalizado na figura do CAJE, pode desenvolver na comunidade sociedade ações de cunho socioeducativo, inscrita no campo político-ideológico, nos marcos institucionais das políticas públicas e privadas. Assim, é incontestável a função educativa desempenhada pelos assistentes sociais nos diferentes espaços ocupacionais institucionais. Tal função caracteriza-se pela incidência dos efeitos das ações profissionais na maneira de pensar e agir dos sujeitos envolvidos nas referidas ações, interferindo na formação da subjetividade e normas de condutas, elementos estes constitutivos de um determinado modo de vida ou cultura. (GRAMSCI, 1979-1981). Essa nova maneira pode ser estimular atitudes que possam caminhar no sentido da superação dos preconceitos baseados na diferença de gênero ainda referenciada na biologia entre os sexos. Muitas vezes observa-se no ambiente do CAJE normatização da formação de grupos e filas por sexo, o reforço das condutas adequadas e esperadas para o menino e para a menina, e a recompensa pelo ‘bom comportamento’; e até mesmo o privilegio quantificado por uma argumento reacionário baseados em dados quantitativos podem ser 33 adolescentes infratoras de um universo de 190 adolescentes do total; mas elas existem e não podem ser invisibilizadas por serem um numero menor.

Sendo assim, a atuação do profissional de Serviço Social no projeto da Rádio Comunitária no CAJE está vinculada à esfera da produção teórico-metodológica e técnica que será implementada a partir de demandas advindas das próprias adolescentes. Tal atuação resultará em um processo coletivo de construção dos programas dentro da unidade que serão executados na figura do Estado. É preciso trabalhar para reconstruir e ressignificar o imaginário acerca das experiências culturais das (os), para superar preconceitos e estereótipos presentes nas demandas institucionais. Há ainda a necessidade de reflexão sobre as convenções naturalizadas pela sociedade, e reproduzidas pela educação, que diferenciam os comportamentos de meninos e meninas. Com referência à prática corporal por exemplo dentro de toda gama de informações apresentadas na analise de dados, em geral, os meninos dispõem de todo pátio ou quadra, onde correm, lutam, jogam, competem, em suma, preparam-se para a vida adulta. Enquanto que para as meninas basta um pequeno espaço, de preferência à sombra, onde se sintam estimuladas a conversar ou, no máximo jogar um golzinho improvisado. Por isso, as(os)assistentes sociais precisam estar atentos(as) aos rituais da instituição para que ali não se corra o risco de a educação conservar, valorizar e perpetuar padrões de comportamentos diferenciados entre os sexos. É no processo 
socioeducativo que também se aprende o que falar e o que silenciar, desta forma ali colocamos todas as nossas expectativas de resistência e superação de padrões relacionados a gênero, raça, classe pensando na invenção de novos comportamentos que demarquem novos arranjos sociais e culturais numa ação entre meninos e meninas.

\section{CONSIDERACÕES FINAIS}

Aceitar, portanto o tratamento institucional até então voltado à adolescentes infratoras privadas de liberdade no D.F - dos "maus tratos cotidianos" àqueles "de não reconhecimento da diferença" oprime e simplesmente desconsidera um tratamento adequado de respeito as diferenças de gênero, constrange e recria um prospecto de que o cárcere não age de forma socioeducativa. $\mathrm{O}$ instrumento de medida que este estudo aponta, ainda não é suficiente para mudar essa situação, mas ao menos dará condições para conhecer sua extensão e antecipar suas conseqüências; isto $\mathrm{o}$ faz útil nos estudos que tratem da questão do preconceito/discriminação contra essas adolescentes.

\footnotetext{
"Aquilo que parecia ser individual, pessoal, que para as mulheres se agudizava em razão da dicotomia público/privado, na experiência do grupo de reflexão ganha inteligibilidade como a construção social, no caso, a de gênero. Duas figuras de discurso dão conta desta percepção: a idéia do "eu coletivo" e "o pessoal é político". O feminismo, exemplo de prática e ideologia de um universo individualista, ao pôr em prática e valorizar a experiência individual, relativiza-a, descobrindo-a no interior do social. Produzindo essa visão totalizadora está dada sua condição e sua força de fazer política (SWAIN, 2003).
}

Pensar em políticas públicas para o cumprimento de medidas socioeducativas sensíveis a categoria gênero, nascido do debate, ou embate, entre natureza e cultura, pode nessas linhas nos apresentar algumas relevantes questões em torno da permanente desigualdade entre mulheres e homens. Formulo aqui que, a natureza sempre foi utilizada como uma desculpa, ou uma vantajosa saída, para a explicação e legitimação das desigualdades entre os sexos. Fechando os olhos para a construção social da desigualdade, e também da igualdade, o mundo impôs às mulheres durante séculos a invisibilidade.

Porém, mesmo com o avançar da emancipação feminina, no trabalho, casa ou escola, a discriminação e o acesso desigual ao que realmente é dado valor na sociedade contemporânea está longe de acabar. No plano individual, interacional ou institucional os homens permanecem na vantagem (WHARTON, 2005). Podemos então analisar gênero em 
um só plano? Se a resposta for afirmativa, que plano seria esse ou, qual dos planos apresentados demonstra maior relevância a ponto de responderem nosso desafio, ou seja, demonstra visualizar e compreender os caminhos percorridos pela sociedade que nos leva a um ambiente onde homens e mulheres têm acesso desigual a recursos e bens simbólicos escassos?

Não seria sensato resumir ou escolher uma só trilha para um atento estudo sobre este tema. Os caminhos para o pleno entendimento de nossa formulação passam tanto pelo individual, como por suas relações diárias, e ainda por sua construção organizacional. Com efeito, podemos entender gênero como um sistema de práticas sociais que constituem as pessoas como diferentes e que organiza as relações de desigualdade, devendo desta forma ser compreendido tanto do ponto de vista individual, como através das práticas sociais que produzem o gênero da pessoa. Estas práticas sociais moldam as relações sociais e os padrões de interação e opera como parte da maioria das organizações e instituições.

Cabe aos gestorxs quando forem formular políticas publicas com recorte de gênero no CAJE criarem as condições necessárias para criar um sistema de notificação e desconstrução de forma a incorporá-la à rotina das atividades de atendimento e ao quadro organizacional dos serviços, além de fomentar a capacitação dxs profissionais que trabalham diretamente com o atendimento das adolescentes; sejam nas questões referentes a saúde ou da educação por exemplo para o atendimento dessa demanda que se coloca no topo da agenda da saúde pública hoje no Brasil. As políticas públicas governamentais predominantes — na área de adolescentes infratoras e em outros campos sociais - ainda não visam promover um processo que altere as estruturas de poder.

As Políticas Públicas ainda estão nos moldes de coerção e não rompem com o paradigma de serem paliativas e facilitam a distribuição mais do que a redistribuição dos bens sociais porque, embora aumentem a representação dos grupos oprimidos, não despertam neles novas compreensões e visões sociais. Conforme o desenvolvido neste trabalho, podem ser fornecidas três estratégias para o padrão de comportamento do Estado na figura do CAJE:

1. A primeira se estrutura em teorias relativas à adoção e implementação de inovações e trata as políticas públicas de gênero como uma ocorrência de significativa inovação organizacional. Embasada em uma síntese de pesquisa persuasiva sobre a implementação de inovações, FULLAN (1994) afirma que se as características da inovação forem imprecisas, ou se os governos tiverem um grande número de burocratas incompetentes, que não possuam 
capacidades de implementar a inovação dentro de seu sistema ou não contem com o conhecimento técnico para avaliar os custos da nova prática, a inovação a ser tentada fracassará em ser implementada (MCDONNELL e ELMORE, 1987). Ao revisar as várias políticas públicas de gênero, parece haver a necessidade de uma maior clareza concernente à natureza das inovações, mas a disposição dos Estados em operar principalmente através de políticas públicas de coerção e de destinar poucos recursos para todos os tipos de políticas públicas de gênero sugere que esta hipótese não se encaixa.

2. A segunda verifica a necessidade de utilizar e ampliar os conceitos de pluralismo e políticas públicas de interesse de grupo propostos por DAHL (1967), argumenta que os Estados não implementarão inovações se não encontrarem pressão suficiente para que o façam. Sob esta perspectiva, poderia se dizer que as políticas públicas de gênero emergiram através da pressão dos movimentos de mulheres e de feministas mas, embora estes atores tenham encontrado condições de exercer pressão para a adoção de legislação, seus pontos de apoio subseqüentes em questões de alocação de fundos e de monitoria da política pública de implantação foram muito fracos.

3. A terceira faz referencia a priorização, que os Estados estabelecem na construção das políticas publicas, do fator econômico em detrimento dos interesses coletivos. Entretanto, por existir, no momento, uma crise de legitimidade - com Estados industrializados sendo contestados e criticados ao mesmo tempo e de forma crescente - eles precisam se envolver em ações simbólicas, democráticas mas relativamente inócuas, a fim de demonstrar sua boa vontade em responder a todos os cidadãos (EDLEMAN, 1972). Como a maioria das políticas públicas de gênero não questionam relações entre mulher e homem, mas tratam o gênero como uma "categoria aditiva" (AGARWAL, 1994), as estruturas sociais básicas são mantidas. Numa colocação contrária à posição assumida por GELB e PALLET (1982) de que os Estados mudam lentamente porque são liberais e preferem se envolver em mudanças incrementais, poderia se argumentar que estes - liberais ou não - mudam lentamente porque são patriarcais e não desejam alterar um status quo que é benéfico a seus interesses. De qualquer forma, inúmeras políticas públicas de gênero poderão ser formuladas, mas a ênfase em sua aprovação será nitidamente simbólica. Como resultado, a implementação de políticas públicas se enfraquece pela limitada alocação de fundos e pela redução desses recursos com o tempo, pela redefinição das intenções legais ou pela afirmação de que o "problema" de gênero foi solucionado. 
Mesmo manifestando soluções dentro do sistema vigente, em uma sociedade com um projeto societário fascista com raízes fortes na higienização cultural que cria relações verticalizadas de poder com o individualismo aflorado em um sistema capitalista que criam países "ricos" sangue-sugas que fizeram sua riqueza em cima da população expropriada pelo Capital no mundo inteiro. Essa dominação explora, assassina, rouba muitas Áfricas e Brasis, portanto é necessário ponderar outras formas de ver/olhar/ a sociedade que vivemos em um processo de revolução social. Se for feito, no mínimo, uma contextualização do local de fala dessas adolescentes; um prospecto, nem sei se é assim que chama, sócio-cultural na qual elas estão inseridas.

O tratamento que o Estado dá as diversas vulnerabilidades sociais oriundas do próprio sistema capitalista não leva em consideração as necessidades humanas em sua magnitude oferecendo respostas que no caso aqui estudado traduzem-se em uma política de extermínio, modelo que deve ser rompido radicalmente através de outras formas de compreensão das realidades, na verdade quem tem que merecer medida socioeducativa é o ESTADO; um ajuste de conduta em relação aos direitos humanos.

Corrobora, então para a conclusão de que o cárcere deve deixar de existir seria. Tal medida seria uma alternativa totalmente viável, pois o sistema penal, do qual o CAJE faz parte reproduz estereótipos e preconceitos sociais, inclusive os das relações de gênero, operando de forma sexista. A não existência dos sistemas de cárcere é sustentada pelo movimento anti-cárcere que existe desde meados do inicio do século XX. Seria uma forma viável para solucionar conflitos criando diálogos interculturais que permitam a criação de alternativas, ou por experiência de outras comunidades não eurocêntricas que já tem algumas formas de resolução de conflitos que queiram fortalecê-las/ modificá-las ou ainda por comunidades que queiram criar suas próprias formas de resolução de conflitos.

A eliminação do cárcere pode ser entendida por muitas pessoas como utopia; $\operatorname{anarquistas}^{63}(2007)$ escreveram um livro chamado a "Sociedade do invisível por uma vida menos desumana" nos revela que no mundo contemponareo capitalista etnocêntrico faz questão de demonizar a palavra utopia como forma de rebaixamento, temos que ser utópicos

\footnotetext{
${ }^{63} \mathrm{O}$ livro não possui nenhuma assinatura só sabemos que tem cientistas/ativistas/militantes representados por todos os continentes dentro da tradição anarquistas e suas vertentes. O motivo do livro não ser assinado é pelo simples fato de que o conhecimento é sempre fruto de nos dês [construções] e tudo que foi produzido ali são sentimentos/valores/morais
} 
mesmo; pois todas as grandes revoluções da historia da humanidade que lutaram e morreram queimadas pelo reconhecimento das mesmas como sujeito de direitos por exemplo, começaram de forma utópica.

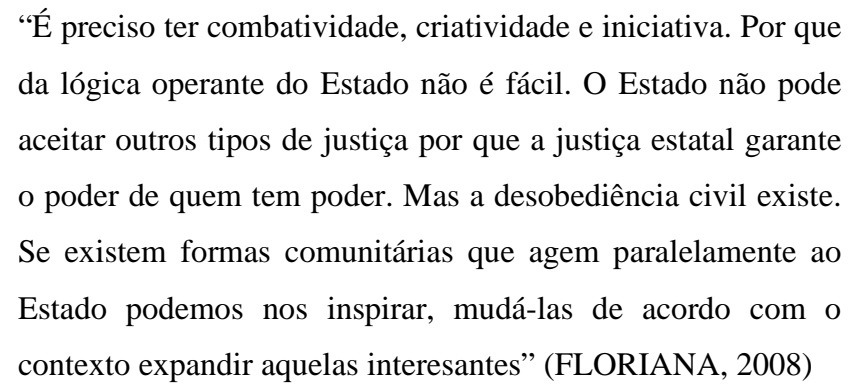

Neste processo de construção identitária, a imaginação e a justiça são instrumentos possibilitadores de narrativas - a pequena história pessoal é parte de uma grande história. Este é um dos principais caminhos por meio do qual uma pessoa elabora e assimila significados, constrói sua identidade e descobre quem ela é (EGGERT , 2002). 


\section{REFERÊNCIAS BIBLIOGRÁFICAS}

ACKER, Joan. Hierarchies, jobs, bodies: a theory of gendered organizations. In: LOBER, Judith; FARREL, Susan. The social construction of gender. Newbury Park: Sage, 2007.

ANDERSON, Perry. Balanço do neoliberalismo. In: SADER, Emir \& GENTILI, Pablo (orgs.) Pósneoliberalismo: as políticas sociais e o Estado democrático. Rio de Janeiro: Paz e Terra, 1995, pp. 09-23.

ANDI/IAS/UNESCO. Os jovens na mídia. Série Mobilização Social. Edição Agência de Notícias dos Direitos da Infância, Instituto Ayrton Senna, Unesco, Brasília, 2000.

ADORNO, T. Mínima moralia. São Paulo: Ática, 1993.

ATHAYDE, Celso; BILl, MV; SOARES, Eduardo. Cabeça de Porco. Rio de Janeiro: Objetiva, 2005.

ALTHUSSER, L.; Aparelhos Ideológicos de Estado (Notas para uma Investigação); Lisboa; Editorial Presença; 1980.

AZEVEDO, M. A. e GUERRA, V.N. de A. (orgs.). Infância e violência doméstica: fronteiras do conhecimento. São Paulo, Cortez Editora, 2005. .

BECKER, H. (1994) Métodos de Pesquisa em Ciências Sociais. 2a. ed. São Paulo: Hucitec.

BIRMAN, Joel. Gramáticas do erotismo: a feminilidade e as suas formas de subjetivação em psicanálise. Rio de Janeiro: Civilização Brasileira, 2001.

BOURDIEU, Pierre. A dominação masculina. 2. ed. Rio de Janeiro: Bertrand Brasil, 2002.

, Pierre. Problemas do Pos-Estruturalismo. Rio de Janeiro, Zahar, 2007.

BRASIL; CONSTITUIÇÃO DA REPÚBLICA FEDERATIVA DO BRASIL. DE 1988.

BRASIL; ESTATUTO DA CRIANÇA E DO ADOLESCENTE; Lei 8069 de 13 de julho de 1990.

BRASIL; CÓDIGO PENAL; Lei Editora Saraiva; 1983.

BRENNER, Karine; MONTEIRO, Elaine. IPEA. Texto 979 - “Adolescentes em Conflito com a lei. Situação de atendimento institucional no Brasil, 2007.

Disponível em'http://WWW.ipea.gov.br/pub/td $/ 2003 / \mathrm{td} 0979 . \mathrm{pd} \mathrm{f}$

BRUSCHINI, Cristina (org.) Uma questão de gênero. Rio de Janeiro: Rosa dos tempos, 1992. 
BUTLER, Judith. Problemas de gênero: feminismo e subversão da identidade. Rio de Janeiro: Civilização Brasileira, 2003.

CAMARGO, A. (1984) Os Usos da História Oral e da História de Vida: trabalhando com elites políticas. dados - Revista de Ciências Sociais. Rio de Janeiro, v.27, n.1, pp.5-28.

CASTEL, Robert. “As armadilhas da exclusão".Desigualdade e a questão social. In: Castel, R; Wanderley, L.E; Wanderley-Belfiore, M. São Paulo, EDUC, 1997.

Robert. A nova questão social. In: As metamorfoses da questão social: uma crônica do salário. Rio de Janeiro. Vozes, 1998.

CASTRO, Mary Garcia. "Marxismo, feminismos e feminismo marxista - mais que um gênero em tempos neoliberais". Crítica Marxista, n. 11, 2000. pp. 98-108. (Dossiê Marxismo e feminismo).

CARVALHO, Marília Pinto de. "Gênero e trabalho docente: em busca de um referencial teórico". In: BRUSCHINI, Cristina; BUARQUE DE HOLLANDA, Heloísa (Orgs.). Horizontes plurais: novos estudos de gênero no Brasil. São Paulo: Editora 34/Fundação Carlos Chagas, 1998.

CARNEIRO, Sueli. "A mulher negra na década - a busca da autonomia. Apresentação". Cadernos Geledés no 5, São Paulo, outono 1995.

CARRANZA, Maria. "Saúde reprodutiva da mulher brasileira". In: SAFFIOTI, Heleieth I. B.; MUÑOZ-VARGAS, Monica (Orgs.). Mulher brasileira é assim. Rio de Janeiro/Brasília: Rosa dos Tempos-NIPAS/UNICEF, 1994. p. 95-150.

CLAVES/ENSP/FIOCRUZ. Avaliação do convênio Uerj \& Degase: programa próadolescente: ações socioeducativas. Relatório de Pesquisa. Claves, Rio de Janeiro, 109pp, 1999.

CONNEL, Robert, (1987). Gender and power. Stanford: Stanford University Press.

(1994). The state, gender and sexual politics: theory and appraisal. In: RADTKE, Lorraine, STAM, Henderikus (orgs.). Power/ gender: social relations in theory and pratice. Londres: Sage.

COSTA, Ana Alice Alcântara. "Trajetória e perspectivas do feminismo para o próximo milênio". In: PASSOS, Elizete; ALVES, Ívia; MACEDO, Márcia. Metamorfoses: gênero nas perspectivas interdisciplinares. Salvador: UFBA, Núcleo de Estudos Interdisciplinares sobre a Mulher, 1998. p. 25-37.

COSTA, Antônio C. Gomes da; Meninas da Vida; FUNABEM, 1989.

CRUZ NETO, Otávio; MOREIRA, Marcelo Rasga. Trabalho infanto-juvenil: motivações, aspectos legais e repercussão social. Cad. Saúde Pública, Rio de Janeiro, v. 14, n. 2, 1998 . 


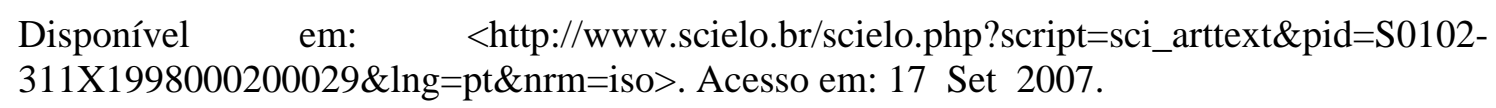

CRUZ-NETO, O. \& MINAYO, M. C. S., 1994. Extermínio, violentação e banalização da vida. Cadernos de Saúde Pública, 10 (Sup.1):199-212.

DAHL, Robert, (1967). Pluralist democracy in the United States: conflict and consent. Chicago: Rand McNally.

DAYRELL, Juarez Tarcisio. Juventude, grupos de estilo e identidade. Educação em Revista. Belo Horizonte, 1999.

DENZIM, N.K. (1984) Interpretando as Vidas das Pessoas Comuns: Sartre, Heidegger e Faulkner. dados - Revista de Ciências Sociais. Rio de Janeiro, v.27, n.1, pp.29-43.

DINIZ, E. 1998. Governabilidade, “Governance” e Reforma do Estado: Considerações Sobre o Novo Paradigma.

EGGERT E 2002. Narrativa: uma filosofia a partir da experiência das mulheres, pp. 193-202. In M Tiburi et al.(org.). As mulheres e a filosofia. Unisinos, São Leopoldo.

ESPINOZA, Olga. A mulher encarcerada em face do poder punitivo. São Paulo: IBCCrim, 2004.

FALEIROS, V. P., 1995. Infância e processo político no Brasil. In: A Arte de Governar Crianças (F. Pilotti \& I. Rizzini, org.), pp. 47-98, Rio de Janeiro: Instituto Interamericano del Niño/Editora Universitária Santa Úrsula/Amais Livraria e Editora.

FANON, Frantz. Los condenados de la tierra. Prefácio de Jean-Paul Sartre. Trad. De Julieta Campos. $2^{a}$ ed. México, Fondo de Cultura Econômica, 1982.

FARAH, Marta Ferreira Santos. Gênero e políticas públicas. Iniciativas de governos subnacionais no Brasil. São Paulo: NPP/FGV-EAESP, 2002 a. (Relatório de pesquisa n. 10/2002).

FARAH, MARTA FERREIRA SANTOS. Gênero e políticas públicas no nível subnacional de governo. Anais do XXVI Encontro Anual da ANPOCS, 22 a 26 de outubro de 2002 b, Caxambu (CD).

FLAUZINA, Ana Luiza Pinheiro. Corpo negro caído no chão: o sistema penal e o projeto genocida do Estado brasileiro. Rio de Janeiro: Contraponto, 2008.

FOUCAUlT, M., 1987. Vigiar e Punir. História da Violência nas Prisões. Petrópolis: Vozes.

FRAISSE, G. (1991). Da destinação ao destino. História filosófica da diferença entre os sexos. Em G. Duby \& M. Perrot (Org.), História das mulheres no Ocidente. Século XIX. pp. 59-96. Porto, Portugal: Afrontamento. FRAISSE, G. (1991). Da destinação ao destino. 
História filosófica da diferença entre os sexos. Em G. Duby \& M. Perrot (Org.), História das mulheres no Ocidente. Século XIX. pp. 59-96. Porto, Portugal: Afrontamento.

FRINHANI, Fernanda de Magalhães Dias; SOUZA, Lídio de. Mulheres Encarceradas e Espaço Prisional: uma Análise de Representações Sociais. Revista psicologia: teoria e prática, n. 7, Vitória, p.61-79, 2002.

FUCKS, Andréa M. S. L. Entre o Direito Legal e o Direito Real: o desafio à efetivação da cidadania do adolescente autor de ato infracional, Brasília, Dissertação de Mestrado/UnB, julho de 2004.

FUJIWARA, Luis. Governo: substantivo feminino? Gênero e políticas públicas em governos subnacionais. São Paulo, FGV-EAESP, 2002 (Dissertação de mestrado em Administração Pública e Governo).

FULLAN, Michael. Implementation of inovations. In: TORSTEN, Husen, POSTLETHWAITE, Neville (orgs.). The international enciclopedia of education. $2^{\mathrm{a}}$ ed.. Kidlington: Elsevier Science, 1994.

FUKUYAMA, F. A grande ruptura: A natureza humana e a reconstituição da ordem social. Rio de Janeiro: Rocco, 2002.

GERTZ, Cliford. A interpretação das culturas. Rio de Janeiro: Guanabara, 1998.

GOFFMAN, Erving. Estigma: notas sobre a manipulação da identidade deteriorada. Rio de Janeiro: Editora Guanabara Koogan”,1988.

GOLDWERT, M. (1985). Mexican machism: The flight from femininity. Psychoanalytic Review, 72, 161-169.

GOMES, Nilma Lino. Sujeitos coletivos e Políticas Públicas. In: SOARES Leôncio; GIOVANETTI, Maria Amélia G. Castro \& GOMES, Nilma Lino (org.). Diálogos na educação de jovens e adultos. Belo Horizonte: Autêntica, 2005.

GOMIDE, Pic. Menor infrator: a caminho de um novo tempo. Editora Juruá, Curitiba, 1990.

GRAMSCI, Antonio. Maquiavel, a política e o estado moderno. Rio de Janeiro. Civilização Brasileira; 1979.

Materialismo histórico e a filosofia de Benedetto Croce. Rio de Janeiro: Civilização Brasileira; 1981.

HEILBORN, Maria Luiza. Gênero: Uma Breve Introdução. Disponível em: http://www.coepbrasil.org.br/opiniao_genero.asp. Acesso em: 30/08/2006 
HEILBORN, Maria Luiza; SORJ, Bila. Estudos de Gênero no Brasil. In: O que ler na Ciência Social Brasileira (1970-1995). Sociologia (Volume II). São Paulo: Sumaré/ANPOCS, 1999.

HOFSTEDE, G. (1991). Cultures and organizations: Software of the mind. London: McGraw-Hill.

IRIGARAY, Luce; RUBIN, Gale Ce Sexe qui n'en est pas un. Paris, Minuit, 1977; L'Ordre Sexuel du Discours. Langages, $\mathrm{n}^{\circ}$ 85, pp.81-123, 1987; KOFMAN, Sarah. La question des femmes: une impasse pour les philosophes. Les Cahiers du Grif, Deuxtemps Tierce, printemps, 1998 ,pp.65-73.

IZUMINO, Wania Pazinato. Justiça e violência contra a mulher: o papel do sistema judiciário na solução de conflitos de gênero. São Paulo: Anna Blume, FAPESP, 1998.

KERGOAT, Daniele. (1978). Ouvriers = ouvrières?, Critiques de l'économie politique, Nouvelle série $n^{\circ}$ 5, Paris, p. 65-97.

. (1982). Em defesa de uma sociologia das relações sociais in: O sexo do trabalho. São Paulo e Rio de Janeiro: Editora Paz e Terra, p.79-93.

(1996). Relações sociais de sexo e divisão sexual do trabalho in: LOPES, M.J.M., Pringle, R. (1997). Feminist theory and the world of the social. Current Sociology

LAVINAS, Lena. "As mulheres no universo da pobreza: o caso brasileiro". Revista Estudos Feministas, v. 4, n. 2, p. 464- 479, 1996.

“Gênero, cidadania e adolescência". In: MADERIA, Felícia Reicher. Quem mandou nascer mulher: estudos sobre crianças e adolescentes pobres no Brasil. Rio de Janeiro: Editora Rosa dos Tempos/UNICEF, 1997.

"Políticas públicas de gênero: considerações". In: Gênero nas administrações: desafios para prefeituras e governos estaduais. São Paulo: Fundação Friedrich Ebert, 2000. p. 36-38. Trecho de exposição.

LEAL, Maria Lúcia Pinto. Relatório Final da Pesquisa Perfil dos adolescentes que morreram enquanto cumpriram medida socioeducativas de internação, semi-liberdade e liberdade assistida no Distrito Federal, no período de 2003 - 2005. In: Oficina de Lançamento da Pesquisa, 2007, Brasília: Ministério Público do Distrito Federal e Territórios (MPDFT).

LOURO, G 2002. Epistemologia feminista e teorização social - desafios, subversões e alianças, pp. 11-22. In MA Adelman \& CB Silvestrin (orgs.). Gênero plural - coletânea. Ed. UFPR, Curitiba.

LOURO, Guacira Lopes (org.). O Corpo Educado: pedagogias da sexualidade. Belo Horizonte: Autêntica, 2001. 
LUKÁCS, Gyorgy. Velha E Novacultura. Publicado originalmente em 1920 na revista Kommunismus, $n^{\circ} 43$. A presente tradução para o português tem por base a publicação deste texto no livro Revolución y Antiparlamentarismo (Ediciones Pasado y Presente, México, 1978). http://WWW.geocities.com/autonomiabvr/nova.htmli

MAFESSOLLI, M. El ritual y la vida cotidiana como fundamentos de las historias de vida, pp. 109-120. In JM Marinas \& C Santamaría. La historia oral - metodos y experiencias. Debate,Madri, 1997

McDONNELL, Loraine, ELMORE, Richard, (1987). Getting the job done: alternative policy instruments. Educational evaluation and policy analisys, v. 9, no 2, p. 133- 153, Washington.

MOREIRA, Marcelo Rasga. Nem soldados, nem inocentes: jovens e tráfico de drogas no município do Rio de Janeiro. [Mestrado] Fundação Oswaldo Cruz, Escola Nacional de Saúde Pública; 2000.

MUCCHIELLI, Roger. L’Analyse de Contenu. Paris, ESF Éditeur, 2002.

MUNIZ, Diva do Couto Gontijo. Corpo feminino e formas de violência: discursos e práticas. In: Mulheres em ação: práticas discursivas, práticas políticas; organizadoras, Tânia Navarro Swain e Diva do Couto Gontijo Muniz. Florianópolis: Ed. Mulheres; Belo Horizonte: PUC Minas, 2005. p. 305

MURARO, R. M.; BOFF, L. Feminino e masculino: uma nova consciência para o encontro das diferenças. Rio de Janeiro: Sextante, 2002.

NICHOLSON, Linda. "Interpreting Gender." Sings: Journal of Women in Culture and Society, Chicago, v. 20, n.1, 1994. p. 79-105.

OLIVEIRA, Dijaci; GERALDES, Elen, LIMA, Ricardo (orgs). Primavera já partiu: retrato dos homicídios femininos no Brasil. Brasília - MNDH (Violência em Manchete) v. 1, 1998.

OLIVEIRA, M. B., 1998. Os Porões da Pólis. In: A Pesquisa nas Ciências do Sujeito. (L. Dupret, org.), pp. 107-129, Rio de Janeiro: Revinter.

PASSETTI, Edson. "Crianças carentes e políticas públicas". In DEL PRIORE, Mary (org.). História das Crianças no Brasil. São Paulo: Ed. Contexto, 2002, p.347-375.

PATEMAN, Carole. O contrato sexual. Rio de Janeiro, Paz e Terra, 1993.

PENA, M. (1991). Class, gender, and machismo: The treacherouswoman folklore of Mexican male workers. Gender \& Society, 5, 30-46.

PERRUCI MF. A Violência e Mulher, Symposium R Unicap 1997; 29(2): 55-60

PIERUCCI, Antônio Flávio. Ciladas da Diferença. São Paulo: Editora 34, 2006. 
PINTO, Céli Regina Jardim. Uma história do feminismo no Brasil. São Paulo: Editora da Fundação Perseu Abramo, 2003, p.15.

PISCITELLI, Adriana. "Re-criando a (categoria) mulher?. In: ALGRANTI, Leila Mezan (org.). A prática feminista e o conceito de gênero. IFCH/UNICAMP, Textos Didáticos, $\mathrm{n}$. 48, 2002.

QUEIROZ, M.I. Relatos orais: do “indizível” ao "dizível”. In: VON SIMSON (org.) Experimentos com Histórias de Vida: Itália-Brasil. São Paulo: Vértice, 1988.

REINHARZ, S. Feminist Methods in Social Research. New York: Oxford University Press, 1992; and traduce in 2008, NASCIMENTO, T.

RIZZINI, I. (orgs.). A Arte de Governar Crianças: história das políticas sociais, da legislação e da assistência à infância no Brasil. Rio de Janeiro: Ed. Universitária Santa Úrsula, 1995, p. 299-346.

RUBIN, Gayle. (1975). The Taffic in Women: Notes on the "Political Economy" of Sex. In: REITER, Rayna R. (org.) Toward na anthropology of women. Nova Iorque: Monthly Review Press, p. 157-210.

SAFFIOTI, Heleieth. Gênero e Patriarcado. In: Marcadas a ferro. Violência contra a mulher, uma visão multidisciplinar. Brasília: Secretaria Especial de Políticas para as Mulheres, 2005.

Rearticulando gênero e classe social. In: COSTA, Albertina de Oliveira; SAFFIOTI, H.I. B. Violência doméstica ou a lógica do galinheiro. In KUPSTAS, M. (org). Violência em debate. São Paulo: Moderna, 1997.

SAFFIOTI, Heleieth I. B. e ALMEIDA Suely de Souza. Violência de Gênero: Poder e Impotência. Rio de Janeiro, Revinter, 1995.

SAFFIOTI, Heleieth I. B. Gênero, Patriarcado, Violência. São Paulo, Editora Fundação Perseu Abramo, 2004.

SALES, Mione Apolinário. (In)visibilidade Perversa: adolescentes infratores como metáfora da violência. São Paulo: Cortez, 2007.

SANTOS, Maria de Fátima Franco dos. Violência sexual contra a mulher cometida por agressor desconhecido da vítima. Campinas, SP: Alínea, 1997.

SANTOS, Vera Lúcia S. Domingues dos. "O papel desempenhado pelo trabalho do (a) preso (a) no seu processo de reinserção social”; 2003.

SCOTT, Joan W. "Gênero: uma categoria útil de análise histórica". Educação e Realidade, Porto Alegre, n. 16(2), p. 5-22, jul/dez. 1990. 
Prefácio a gender and politics of history. Cadernos Pagu. Desacordos, desamores e diferenças. N. 3. p. 11-27. Campinas: IFCH/PAGU, 1994.

. "Igualdade versus diferença: os usos da teoria pós-estruturalista". Debate Feminista. Cidadania e Feminismo (Edição especial). São Paulo: Cia. Melhoramentos, 1999. pp. 203222.

. “'La querelle des femmes' no final do século XX”. Revista Estudos Feministas, v. 9, n. 2/2001, p. 367-388, Florianópolis: CFH/CCE/UFSC.

SINASE - SISTEMA NACIONAL DE ATENDIMENTO SOCIOEDUCATIVO sob Coordenação Geral Subsecretaria de Promoção dos Direitos da Criança e do Adolescente - SPDCA/SEDH e do Conselho Nacional dos Direitos da Criança e do Adolescente _ _ _ CONANDA, Brasília julho de 2006. Disponível em: http://Www.promenino.org.br/Portals/0/Legislacao/Sinase.pdf

SUÁREZ, Mireya; BANDEIRA, Lourdes. Violência, gênero e crime no Distrito Federal. Brasília: Ed. UNB, 1999.

SWAIN, T.N. "De deusa a bruxa: uma história de silêncio". Humanidades. Brasília, Edunb, s.d, 2003.

TORRES, J. B. (1998). Masculinity and gender roles among Puerto Rican men: Machismo on the US Mainland. American Journal of Orthopsychiatry, 68, 16-26.

VÉRAS, Maura P. B., (2003). DiverCidade, territórios estrangeiros como topografia da alteridade em São Paulo - tese livre docência PUCSP.

VEYNE. Paul. Foucault revoluciona a história. In: VEYNE, Paul. Como se escreve a história. Trad. Alda Baltar e Maria Auxiliadora Kneipp. 3. ed. Brasília: Editora Universidade de Brasília, 2004. p. 150-181

VOGEL, A. Do Estado ao Estatuto: propostas e vicissitudes da Política de Atendimento à Infância e Adolescência no Brasil Contemporâneo. In: PILOTI, F.;

VOEGELI, Carla Maria Petersen Herrlein. Criminalidade e Violência no Mundo Feminino. Curitiba: Juruá, 2003.

VOLPI, M.(org.). O adolescente e o ato infracional. São Paulo: Cortez. 1997

(org.) Adolescentes privados de liberdade. São Paulo: Cortez, 2000.

ZALUAR, A. Exclusão e políticas públicas: dilemas teóricos e alternativas políticas.

Revista Brasileira de Ciências Sociais, São Paulo, n. 35, Paulo, 1997. 'LWWw.scielo.org.textò: Acesso em: 27 set. 2008. 
WALBY, Sylvia, (1990). Theorizing patriarchy. Oxford: Basil Blackwell.

WATSON, Juliana Floriana. Do cárcere ao anti-cárcere, Brasília, Monografia/UnB, setembro de 2008 .

WHARTON, Amy. Gender in interactions and institutions. In: The sociology of gender: an introduction to theory and research. Oxford: Blackwell, 2005

WELZER-LANG, D. Les hommes violents. Paris, Lierre \& Coudrier Editeur, 2001.

YATES, Lyn, (1993). Feminism and australian state policy: some questions for the 1990s. In: ARNOT, Madeleine, WEILER, Kathleen (orgs.). Feminism and social justice in education: international perspectives. Londres: The Falmer Press.

\subsection{SITÍOS CONSULTADOS}

Sitio do ANDI. Disponível em: <www.andi.org br>. Acesso em Out 2008

Sitio do CORREIO BRAZILIENSE. Disponível em Nov 2008

Sitio do DEGASE. Disponível em 〈WWW.degase.rj.gov.br>! Acesso em Set 2008; Projeto Perfil da Criança e do Adolescente Infrator Âtendido nas Unidades de Triagem e Internação do DEGASE; 1997. 


\section{ANEXOS}

\section{1 - ANEXO I}

Perfil dos Adolescentes em medida de internação no Distrito Federal Instrumental I - Roteiro para coleta das informações

Unidade de Internação (UI):

Identificação do alojamento:

1. Nome do/a adolescente

2. Sexo

3. Naturalidade

4. Cor/raça

5. Idade

6. Endereço Cidade

7. Tipo de infração cometida

8. Data de entrada na UI

9. Tempo de cumprimento da medida

10. Número de passagem pela UI

11. Escolaridade

\section{CESAMI}

13. Evasão 
14. Saídas

15. Visitas

16. Infrações Cometidas dentro da UI

17. Certidão de Passagem

18. Oficinas 


\section{2 - ANEXO II}

\section{Perfil dos Adolescentes em medida de internação no Distrito Federal Instrumental II - Orientações para os pesquisadores de campo}

Unidade de Internação (UI): CAJE, CIAGO ou CESAME

Alojamento: Identificar o local onde o adolescente está alojado. Ex.: Ala, módulo, sala do castigo etc.

19. Nome do/a adolescente, Sexo, Cor/raça, Idade, Endereço/Cidade, Tipo de infração cometida, Data de entrada na UI, Tempo para cumprimento da medida, Número de passagem pela UI, Escolaridade: Escrever essas informações da mesma forma que estiver no prontuário/processo.

20. Data de entrada na UI: Identificar a data em que o/a adolescente deu entrada na UI

21. Tempo para cumprimento da medida: Em quanto tempo ele cumprirá a medida (Quantos anos, meses, semanas, dias)

22. Número de passagem pela UI: $O$ adolescente pode ser reincidente e estar no CIAGO ou no CESAMI. Caso existam situações como estas, explicar. No prontuário/processo deve ter escrito a outra UI pela qual o/a adolescente passou.

23. Observações: Nesse item, escrever (avaliar se é possível escrever esse item na hora, tendo em vista uma possível fiscalização ao nosso trabalho):

a. dados relevantes do prontuário/processo referentes ao adolescente e que não estão no instrumental

b. dados do prontuário/processo considerados importante: folha arrancada, numeração errada, encaminhamentos com evidencia de não cumprimento, ou estranho, parecer incompleto ou com evidencias de que não foi acatado etc.

24. No diário/relatório de campo, que deve ser elaborado e datado a cada final de jornada, deve conter aspectos da observação de campo, tais como: o ambientelespaço físico, equipamentos, limpeza, relacionamento (adolescentes $X$ funcionários, entre os próprios funcionários, hierarquia), aspecto (organização, informações ou falta delas, condições de manutenção) dos arquivos e dos processos, receptividade dos distintos atores da UI com a nossa presença e outras informações consideradas importantes pelo pesquisador de campo. 


\subsection{ANEXO III}

\section{Instrumental Entrevistas Adolescentes CIAGO/CAJE - Pesquisa "CAJE HOJE" Direitos dos Adolescentes em Privação de Liberdade (ECA)}

Nome:

Raça/Cor (declaração do adolescente):

Entrevista Pessoal com Membro do Ministério Público (EPMP).

Conhece esse direito?

( ) Sim

Como conheceu?

( ) Caje

Praticou esse direito?

Incentivo à prática?

( ) $\operatorname{Sim}$

( ) Não

Dificuldades à prática?

( ) $\operatorname{Sim}$

( ) VIJ/TJDFT ( ) MP

( ) Sim

( ) Não

Comentários:

Peticionar (pedir) diretamente a qualquer autoridade (P).

Conhece esse direito?

( )Sim

( ) Não

Como conheceu? ( ) Caje

Praticou esse direito?

( ) $\mathrm{Sim}$

( ) VIJ/TJDFT

Incentivo à prática?

Dificuldades à prática?

( ) $\mathrm{Sim}$

( ) Não

( ) Não

( ) Não

Comentários:

( ) $\mathrm{Sim}$

( ) Não

( ) Não

Avistar-se (ver-se) reservadamente com seu defensor (ARD).
Conhece esse direito?
( ) Sim
( ) Não
Como conheceu?
) Caje
Praticou esse direito?
Incentivo à prática?
( ) $\mathrm{Sim}$
( ) VIJ/TJDFT
( ) MP
( ) Terceiros
Dificuldades à prática?
( ) $\operatorname{Sim}$
( ) Não
( ) Não
( ) Sim
( ) Não

( ) Terceiros 
Comentários:

Ser informado se sua situação processual, sempre que solicitada (ISP).

Conhece esse direito?

Como conheceu? ( ) Caje

Praticou esse direito?

( ) Sim

( ) Não

Incentivo à prática?

( ) $\mathrm{Sim}$

( ) VIJ/TJDFT ( ) MP $\quad$ ( ) Terceiros

Dificuldades à prática?

( ) Sim

( ) Não

Comentários:

( ) $\mathrm{Sim}$

( ) Não

( ) Não

Comentários:

Ser tratado com respeito e dignidade (RD).

Conhece esse direito?

Como conheceu? ( ) Caje

Praticou esse direito?

( )Sim

( ) Não

Incentivo à prática?

Dificuldades à prática?

Comentários:

( ) $\mathrm{Sim}$

( ) VIJ/TJDFT

( ) $\mathrm{Sim}$

( ) $\mathrm{Sim}$

( ) Não

( ) MP ( ) Terceiros

( ) Não

( ) Não

Permanecer internado na mesma localidade ou naquela mais próxima ao domicílio de seus pais ou responsável (IPP).

Conhece esse direito? ( )Sim

Como conheceu? ( ) Caje ( ) VIJ/TJDFT ( )

Praticou esse direito? ( ) Sim ( ) Não

Incentivo à prática? ( ) Sim Não

Dificuldades à prática? ？ （ ） Sim Não

Comentários: 
Receber visitas, ao menos semanalmente (V).

Conhece esse direito? ( )Sim ( ) Não

Como conheceu? ( ) Caje ( ) VIJ/TJDFT ( ) MP $\quad$ ( ) Terceiros

Praticou esse direito? ( ) Sim ( ) Não

Incentivo à prática? ( ) Sim ( ) Não

Dificuldades à prática? （ ) Sim ～～Não

Comentários:

Corresponder-se com seu familiares e amigos (C).

Conhece esse direito?

( ) Sim Não

Como conheceu? ( ) Caje ( ) VIJ/TJDFT ( ) MP （ ) Terceiros

Praticou esse direito? ( ) Sim ( ) Não

Incentivo à prática? ( ) Sim Não

Dificuldades à prática? （ ) Sim ） Não

Comentários:

Ter acesso aos objetos necessários à higiene e asseio pessoal (HAP).

Conhece esse direito? ( )Sim ( ) Não

Como conheceu? ( ) Caje ( ) VIJ/TJDFT ( ) MP （ ) Terceiros

Praticou esse direito? ( ) Sim ( ) Não

Incentivo à prática? ( ) Sim Não

Dificuldades à prática? ？ ） ( ) Sim Não

Comentários: 
Habitar alojamento em condições adequadas de higiene e salubridade (AHS).

Conhece esse direito? ( )Sim ( ) Não

Como conheceu? ( ) Caje ( ) VIJ/TJDFT ( ) MP ( ) Terceiros

Praticou esse direito? ( ) Sim ( ) Não

Incentivo à prática? ( ) Sim Não

Dificuldades à prática? （ ） Sim ～～Não

Comentários:

Receber escolarização e profissionalização (EP).

Conhece esse direito?

( ) Sim ( ) Não

Como conheceu? ( ) Caje ( ) VIJ/TJDFT ( ) MP $\quad$ ( ) Terceiros

Praticou esse direito? ( ) Sim ( ) Não

Incentivo à prática? （ ) Sim ( ) Não

Dificuldades à prática? （ ) Sim Não

Comentários:

Realizar atividades culturais, esportivas e de lazer (CEL).

Conhece esse direito? ( )Sim ( ) Não

Como conheceu? ( ) Caje ( ) VIJ/TJDFT ( ) MP $\quad$ ( ) Terceiros

Praticou esse direito? ( ) Sim ( ) Não

Incentivo à prática? ( ) Sim ( ) Não

Dificuldades à prática? ？ （） Sim Não

Comentários: 
Ter acesso aos meios de comunicação social (ACS).

Conhece esse direito?

( ) Sim

Como conheceu? ( ) Caje

Praticou esse direito?

Incentivo à prática?

Dificuldades à prática?

Comentários:

( ) $\mathrm{Sim}$

( ) VIJ/TJDFT ( ) MP

( ) Não

( ) $\operatorname{Sim}$

( ) Não

( ) Não

Receber assistência religiosa, segundo a sua crença, e desde que assim o deseje (AR).

Conhece esse direito?

( ) Sim

( ) Não

Como conheceu? ( ) Caje ( ) VIJ/TJDFT ( ) MP （ ) Terceiros

Praticou esse direito?

Incentivo à prática?

Dificuldades à prática?

( ) $\operatorname{Sim}$

( ) Não

( ) $\operatorname{Sim}$

( ) Não

Comentários:

( ) $\operatorname{Sim}$

( ) Não

( ) Terceiros

Manter a posse de seus objetos pessoais e dispor de local seguro para guardá-los, recebendo comprovante daqueles porventura depositados em poder da entidade (POP). Conhece esse direito?

Como conheceu? ( ) Caje

Praticou esse direito?

Incentivo à prática?

( ) Sim

( ) Não

Dificuldades à prática?

( ) $\mathrm{Sim}$

( ) VIJ/TJDFT

( ) $\operatorname{Sim}$

( ) MP

MP ( ) Terceiros

Comentários:

( ) Sim

( ) Não

( ) Não

( ) Não 
Receber, quando de sua desinternação, os documentos pessoais indispensáveis à vida em sociedade (RDP).

Conhece esse direito?

Como conheceu?

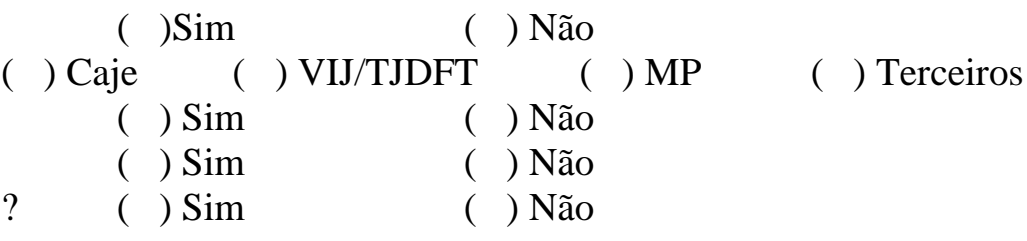

Praticou esse direito?

Incentivo à prática?

Dificuldades à prática?

Comentários:

O que a internação no CAJE vai mudar no seu futuro?

Antes de entrar no CAJE, você teve acesso a serviços de:

( ) Saúde ( ) Profissionalização

( ) Educação ( ) Lazer

( ) Esporte ( ) Cultura

Comentários: 


\subsection{ANEXO IV -}

Tabela de Bibliografia "Pesquisa CAJE HOJE" Levantamento Bibliográfico_2000 a 2006.

Artigos/Teses/Monografias e Obras

Scielo, CAPES, Domínio Publico, PROQUEST, Artigo Cientifico e BCE.

Instrumental Levantamento Documental - Biliografia

Ano Título Autor/a $\left.\begin{array}{l}\text { Palavras- } \\ \text { Chave }\end{array}\right)$ Orientadora(o Resumo




\subsection{ANEXO V - Musica "Vida Loca" Parte I e II do Grupo de RAP "Racionias Mc's"}

\section{Racionais Mc's - Vida Loka - Parte 1}

Fé em Deus que ele é Justo,

Ei irmao nunca se esqueça, na guarda, guerreiro,

Levanta a cabeça truta, onde estiver seja lá como for,

Tenha fé porque ate no lixão nasce flor,

Ore por nós pastor, lembra da gente no culto dessa

noite,firmao segue quente,

Admiro os crente, da licença aqui, mó funçao, mó tabela

Pow, desculpa ai.

Eu me, sinto as vezes meio Pá, inseguro,

Que nem un vira-lata 100 fé no futuro,

Vem alguem lá, quem é quem, quem sera meu bom,

Dá meu brinquedo de furar moleton,

Porque os bico que me ve com os truta na balada,

Tenta ve, que saber de mim não ve nada,

Porque a confiança é uma mulher ingrata,

Que te beija, e te abraça, te rouba e te mata,

Desacredita, nem pensa, só naquela

Se uma mosca ameaça me cata piso nela,

O bico deu mó guela, Ró

Bico e bandidão vao em casa na missao, me tromba na cohab,

De camisa larga, vai sabe Deus que sabe,

Qual é a maldade comigo inimigo num me que,

Tocou a campanhia PLIN, pá trama meu FIM, dois maluco

armado SIM, um isqueiro e um STOPIM,

Pronto pra chama minha preta pra fala,

Que comia mina dele, Rá, se ela tava Lá

Vadia, mentirosa, nunca vi tão mó faia, espirito do mal,

cão, de buceta e saia...

Talarico nunca fui, é o seguinte,

Ando certo pelo certo, como 10 e 10 é 20,

Já penso doido, e se eu to com o meu filho no sofá de

VACILO,

desarmadao era AQUILO,

100 culpa, 100 chance, nem pra abri a boca

Ia nessa 100 sabe

(Pô cê vê) VIDA LOKA...

Mais na rua né não, até Jack

Tem quem passa um pano, 
Impostor pé de breck, passa pro malandro,

A inveja existe, e a cada 10, 5 é na maldade,

A mãe dos Pecado Capital é a Vaidade,

Mais se é para resolver, se envolver, vai meu nome,

Eu vou faze o que, se a cadeia é pra homen,

Malandrão eu, NÃO, ninguem é bobo,

Se quer Guerra terá,

Se quer Paz, quero em dobro,

Mais verme é verme, é o que é,

Rastejando no chão, sempre embaixo do pé,

E fala 1, 2 vez, se marcar até 3,

$\mathrm{Na} 4^{\text {a }}$ xeque-mate, que nem no xadrez,

Eu sou guerreiro do RAP,

E sempre em alta voltagem um por um,

Deus por nós, to aqui de passagem,

VIDA LOKA

Eu não tenho dom pra vitima,

Justiça e Liberdade, a causa é legitima,

Meu Rap faz o cântico do lokos e dos românticos,

Vo por o sorriso de criança, onde for,

Os parceiros tem a oferece a minha presença,

Talvez até confusa, mais Real e Intensa,

Meu melhor Marvin Gaye, sabadão na Marginal,

O que será, será, é nóis vamo até o final,

Liga eu, liga nóis, onde presciso for,

No Paraíso ou no dia do Juízo Pastor,

E liga eu, e os irmão,

É o ponto que eu peço, FAVELA, FUNDÃO,

Imortal nos meus versos,

VIDA LOKA. 


\section{Racionais Mc's - Vida Loka - Parte 2}

Deixa eu falá p'ocê,

Tudo, tudo, tudo vai, tudo é fase irmão,

Logo mais vamo arrebentar no mundão,

De cordão de elite, 18 quilate,

Poê no pulso, logo brait,

Que tal, tá bom,

De lupa, mochilon, bombeta branca e vinho,

Champanhe para o ar, que é pra abri nosso caminhos,

Pobre é o Diabo, eu odeio a ostentaçao,

Pode rir, ri, mais não desacredita não,

É só questão de tempo, o fim do sofrimento,

Um brinde pros guerreiro, Zé povinho eu lamento,

Vermes que só faz peso na Terra,

Tira o zóio,

Tira o zóio, vê se me erra,

Eu durmo pronto pra guerra,

E eu não era assim, eu tenho ódio,

E sei que é mau pra mim,

Fazer o que se é assim,

VIDA LOKA, CABULOSA,

O cheiro é de Pólvora,

E eu prefiro rosas,

E eu que...E eu que...

Sempre quis um lugar,

Gramado e limpo, assim verde como o mar,

Cercas brancas, uma seringueira com balança,

Disbicando pipa, cercado de criança...

How...How Brow

Acorda sangue bom,

Aqui é Capão Redondo, Tru,

Não Pokemon,

Zona Sul é invés, é stress concentrado,

Um coração ferido por metro quadrado...

Quanto mais tempo eu vou resistí?

Pior que eu ja vi meu lado bom na U.T.I,

Meu anjo do perdão foi bom, 
Mais ta fraco,

Culpa dos imundo do espirito opaco,

Eu queria ter, pra testa e vê,

Um malote, de Gloria, Fama,

Embrulhado em pacote,

Se é isso que seis qué,

Vem pega,

Jogar num rio de merda e vê varios pulá,

Dinheiro é Foda,

Na mão de favelado, é mó guela,

$\mathrm{Na}$ crise, varios pedra 90, esfarela,

Eu vou joga pra ganhá,

O meu money, vai e vem,

Porém quem tem, tem,

Não cresço o zóio em ninguem,

O que tiver que ser,

Será meu,

Tá escrito nas estrela,

vai reclama com Deus,

Imagina nóis de Audi,

Ou de Citröen,

Indo aqui, indo ali,

Só Pam,

De vai e vem,

No Capão, no Apurá, vo colá,

Na Pedreira do São Bento,

No Fundão, no pião,

Sexta-Feira,

De teto Solar,

O luar representa,

Ouvindo Cassiano, haaa

Os gambé não guenta,

É mais se não dé,

Nego,

O que é que tem,

O importante é nóis aqui,

Junto ano que vem,

E o caminho,

Da felicidade ainda existi,

É uma trilha estreita,

É em meia a selva triste, 
Quanto cê paga,

Pra vê sua mãe agora?

E nunca maise ve seu Pivete,

Embora,

Da a casa, da o carro,

Uma Glok, e uma Fhal,

Sobe cego e de joelho,

Mil e cem degrau,

Quente é Mil Grau,

$\mathrm{O}$ que o guerreiro diz,

O promotor é só um homem,

Deus é o juiz,

Enquanto Zé Povinho,

Apedrejava a Cruz,

Um canalha fardado,

Guspiu em Jesus,

Óh ...

Aos 45 do segundo arrependido,

Salvo e perdoado,

É DIMAS o bandido,

É loko o bagulho,

Arrepia na hora,

Ó

DIMAS, primeiro VIDA LOKA da historia,

Eu digo,

Gloria...Gloria...

Sei que Deus tá aqui,

E só quem é,

Só quem é vai sentir,

E meus guerreiro de fé,

Quero ourvi....Quero ouvi...

E meus guerreiro de fé,

Quero ouvi irmão...

Programado pra morre nóis é,

É certo...é certo...é crer no que der... 
Firmeza

Não é questão de luxo,

Não é questão de cor,

É questão d fartura,

Alega o sofredor,

Não é questão de Presa,

Nem cor,

A idéia é essa,

Miséria traz tristeza, e vice-versa,

Inconcientemente,

Vem na minha mente inteira,

Uma loja de tênis,

O olhar do parceiro,

Feliz de poder comprar,

$\mathrm{O}$ azul, o vermelho,

O balcão, o espelho,

$\mathrm{O}$ estoque, a modelo,

Não importa,

Dinheiro é puta,

E abre as porta,

Dos castelo de areia que quizer,

Preto e dinheiro,

São palavras rivais,

hééé!!!

Então mostra pra esses $\mathrm{Cu}$,

Como é que faz,

O seu enterro foi dramatico,

Como o blues antigo,

Mais de estilo,

Me perdoe, de bandido,

Tempo pra pensá,

Qué pará,

Que cê qué,

Viver pouco como um Rei,

Ou então muito, como um Zé,

As vezes eu acho,

Que todo preto como eu,

Só qué um terreno no mato,

Só seu, 
Sem luxo, descalço, nadar num riacho,

Sem fome,

Pegando as fruta no cacho,

Ae truta, é o que eu acho,

Quero tambem,

Mais em São Paulo,

Deus é uma nota de 100 ,

VIDALOKA.

PORQUE O GUERREIRO DE FÉ NUNCA GELA, NÃO AGRADA O INJUSTO, E NÃO AMARELA, O REI DOS REI, FOI TRAIDO, E SANGRÔ NESSA TERRA, MAIS MORRER COMO UM HOMEM É O PREMIO DA GUERRA, MAIS Ó,

CONFORME FOR, SE PRECISÁ, AFOGA NO PROPRIO SANGUE SERÁ, NOSSO ESPIRITO É MORTAL, SANGUE DO MEU SANGUE, ENTRE O CORTE DA ESPADA E O PERFUME DA ROSA, SEM MENSÃO HONROSA, SEM MASSAGEM.

A VIDA É LOKA NEGO, E NELA EU TO DE PASSAGEM,

A DIMAS, O PRIMEIRO,

SAUDE GUERREIRO!

DIMAS...DIMAS...DIMAS.. 
This document was created with Win2PDF available at http://www.win2pdf.com.

The unregistered version of Win2PDF is for evaluation or non-commercial use only.

This page will not be added after purchasing Win2PDF. 